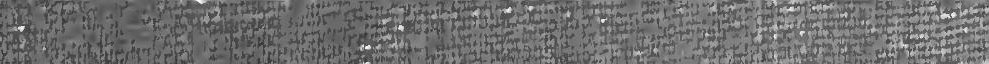
STho bis Qititim

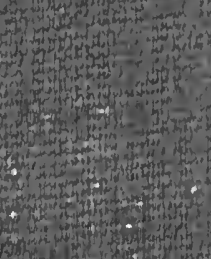
$\rightarrow$ tis

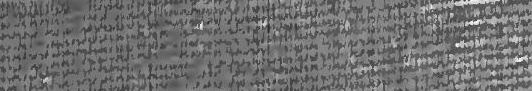

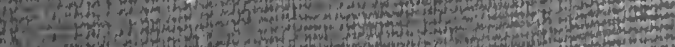

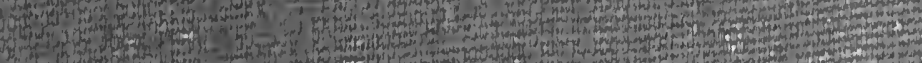
20.

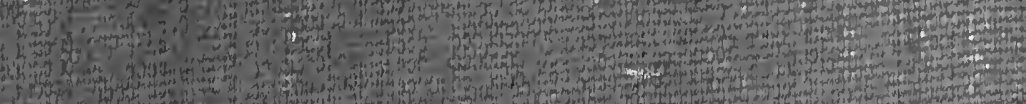
Pof

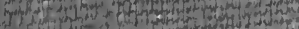
Hot (it)

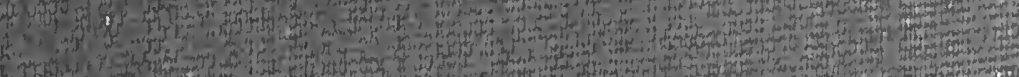

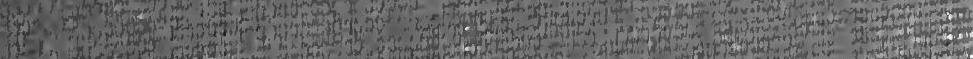

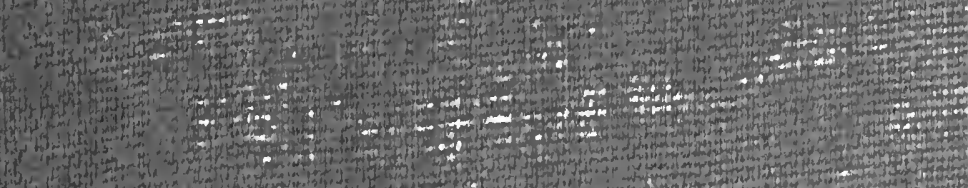
of in (25) (5)

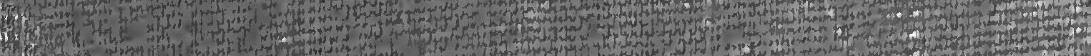

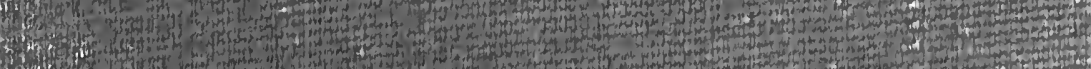

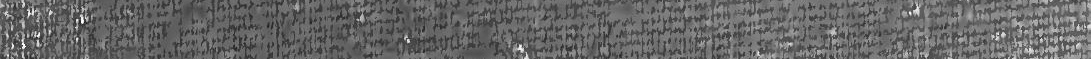
(3)

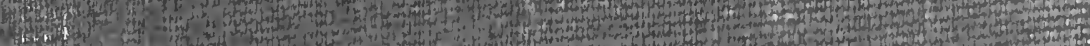

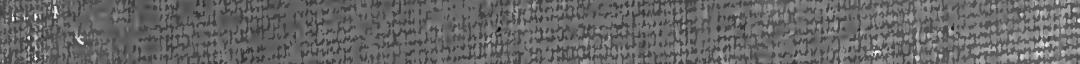
Sow 4. 4. 1 th 
WhW AT LOS ANGELES 


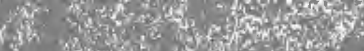

if:

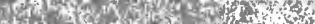

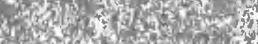

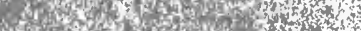

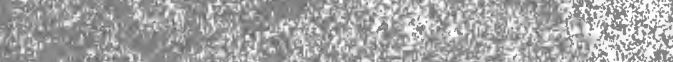
20.

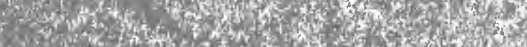
r.t.

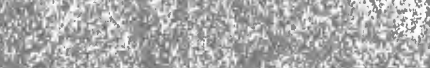
4.

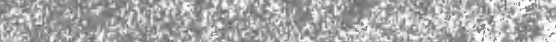

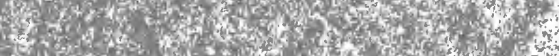

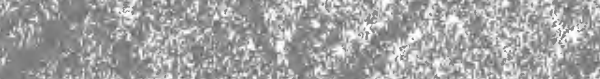
t. H. 5.

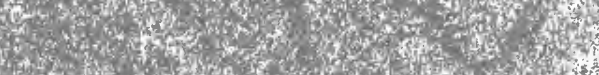

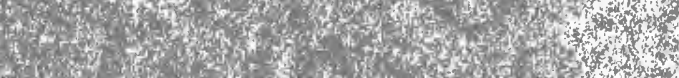

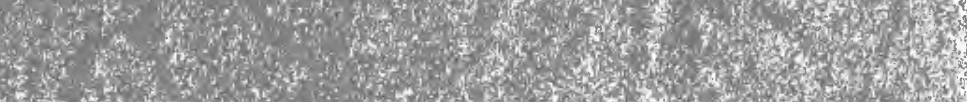

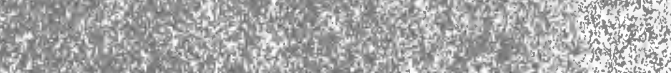

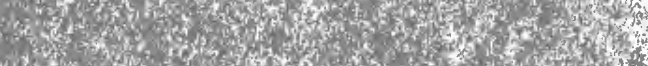

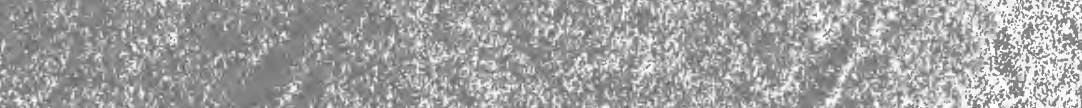

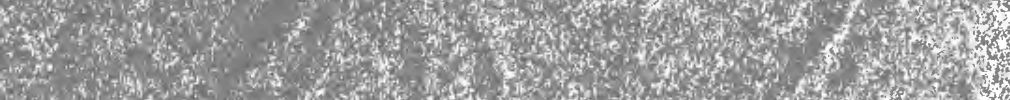

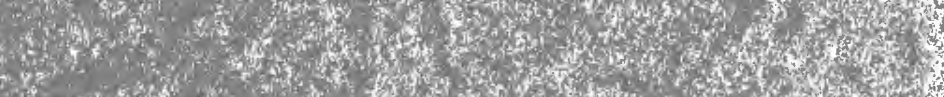

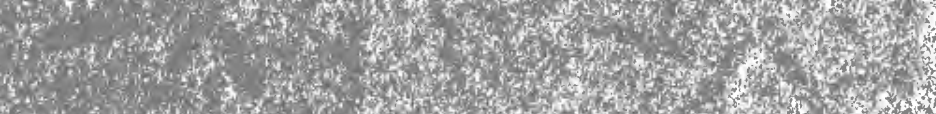

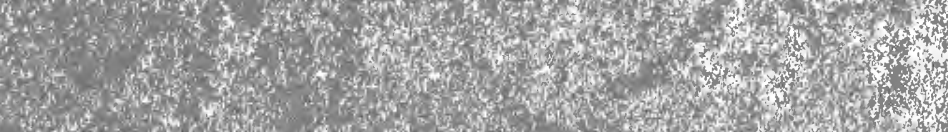

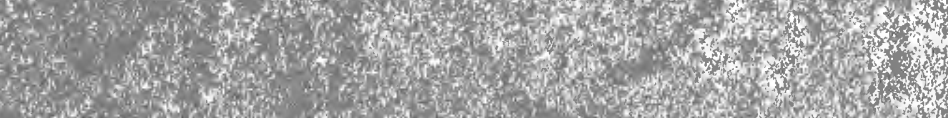
Q

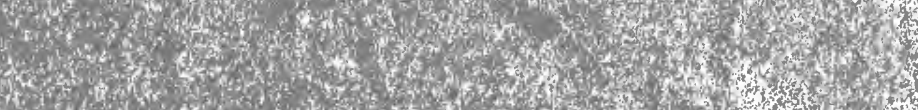

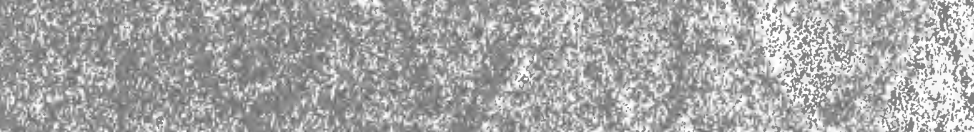
3015) F. 150.

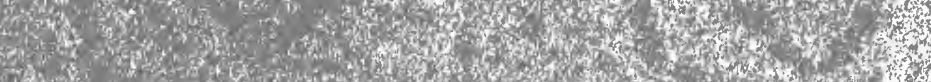

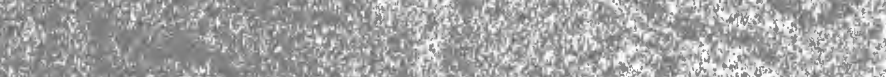

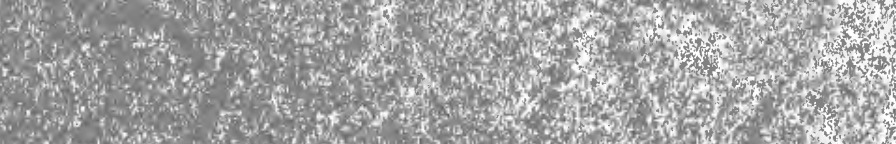
4.70 .

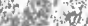
30. ing sitions

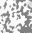



$-1 \sqrt{2+2}$ 
Digitized by the Internet Archive in 2008 with funding from Microsoft Corporation 


\section{THE ECONOMIC UTILIZATION OF HISTORY}




$$
\text { . }
$$




\title{
The Economic Utilization of History and
}

\section{Other Economic Studies}

\author{
By \\ HENRY W. FARNAM \\ Professor of Economics, Yale University
}

New Haven: Yale University Press

London: Henry Frowde

Oxford University Press

MCMXIII 
COPYRIGHT, 1913

By Yale University Press

Printed February, 1913, 1100 copies 
The Economic Utilization of History and Other Economic Studies

ChAPTER

I. The Economic Utilization of History . . . . . . 1

II. Some Questions of Methodology . 18

III. Economic Experimentation in the United States . . . . 34

IV. The Pathology of Progress . . 58

V. Economic Progress and Labor Legislation $\quad . \quad . \quad . \quad . \quad 68$

VI. Fundamental Distinctions in Labor Legislation $\quad . \quad$. $\quad . \quad$. 82

VII. Purposes of Labor Legislation . 94 VIII. Practical Methods in Labor Legislation . . . . . 104

IX. Acatallactic Factors in Distribution

.122

X. A Socialized Business Enterprise . 138

XI. Social Myopia . . . . 165

XII. Signs of a Better Social Vision . 187 



\section{PREFACE}

The contents of this little volume consist in the main of studies which have already appeared in print. All of them have, however, been revised, and the greater part of the first two chapters is new. Though the studies have been written for special occasions during the past four years, they all represent one point of view, and the last nine chapters may be considered an application in the several fields of labor legislation, business organization, and charity, of the scientific methods advocated in Chapters I, II, and III. In order to bring out better this continuity of thought most of the essays have been subdivided, and new titles assigned to them.

Chapters I, II, and III contain the presidential address delivered in Washington in 1911 at the annual meeting of the American Economic Association. Chapters IV, V, VI, VII, and VIII contain presidential addresses delivered before the American Association for Labor Legislation in 1909, 1908, and 1910. Chapters IX and X contain an article originally published in the 
Yale Review for May, 1909, while Chapters XI and XII contain the address delivered in the spring of 1911 by the author as president of the Connecticut Conference of Charities and Correction. Acknowledgment is hereby made of the courtesy of the American Economic Association, of the American Association for Labor Legislation, of the Yale Review, and of the Connecticut Conference of Charities and Correction for permission to use the matter already published by them.

Henry W. Farnam.

Yale University, October, 1912. 
THE ECONOMIC UTILIZATION OF HISTORY 



\section{CHAPTER I}

\section{The Economic Utilization of History}

It is a common, if not a universal, assumption that economics is at a disadvantage as compared with many of the natural sciences, in that it does not admit of laboratory experiments. There are two considerations which support this assumption.

In the first place economics deals with human beings in their social relations. It does not even deal with them as individuals. It must therefore consider large groups, often whole states or groups of states. The economist has neither the power to force, nor the wealth to pay for, experiments upon nations, and if he had, he would in many cases be deterred by moral scruples from attempting them. Such a power might conceivably be exercised by some oriental despot, and such persons have existed. Herod, the son of Antipater, e.g., if he had been as much interested in sociology as he was in poli- 
tics, would have made a good experimenter, since he was not only able but quite willing to put to death all of the children born within a certain time in Bethlehem. Muhammad, the son of Tughlak, who ruled Northern India from 1325 to 1351 , is in the same class. He has been described as "learned, merciless, religious and mad." $\mathrm{He}$ was thus equipped morally and mentally as well as politically for trying social experiments on a large scale. And he did so. For we are told that he "tried to replenish his treasury by the simple expedient of coining brass in vast quantities and ordaining that it should be accepted as silver." "He thus decreed that the King's brass should be equal to the people's silver, and doubtless introduced among his people the familiar phenomena which follow an inflated currency.

But Herod and Muhammad represent past types. The modern economist, even if he were at the same time a great statesman, could not deliberately experiment on a nation without running the risk of being committed either to an insane asylum or a

1 The Imperial Gazetteer of India, The Indian Empire, Vol. II, 1908, p. 145. 
jail. And yet the really important thing for the economist is that experiments be tried, not that he try them himself, and in view of the great cost of social laboratory work the economist is really fortunate in having experiments tried for him without expense to himself and without involving him in any legal or moral liability. $\mathrm{He}$ cannot, it is true, like Herod, kill off the babies for the sake of watching the effect upon population or wealth, but society is constantly creating by law conditions which lead to the slaughter both of innocents and of adults, by preventable disease and accident. ${ }^{2}$ In many cases this needless increase of the death rate is brought about, as it was in the time of Herod, because our officeholders are more intent upon keeping their jobs than upon earning their salaries, and care more for politics than for sociology. We have in a republic no despot to force his brass into circulation, but what no despot would dare do to the people, the sovereign people cheerfully do to themselves. When our country was divided by a civil war, the hostile sections, though bitterly opposed to each other in most 2 For illustrations, see Chap. XI, pp. 168-177. 
questions, were yet alike in that each decreed to make the government's paper equal to the people's gold, and tried over again the experiment of an inflated currency which had been tried by Muhammad, the son of Tughlak, and by many others after him.

Thus we not only have experiments tried on a large scale in modern states, but it is fair to say that, the more democratic the country, the more ready on the whole it is to try experiments on itself. Indeed, economic experimentation is not only possible, but it is so common that it is hardly recognized as experimentation, and the superabundant legislative activity of so many of our advanced and radical commonwealths testifies to the mass of work of this kind which is being performed gratuitously for the economist.

There is a second argument against the possibility of economic experimentation, which is perhaps more serious than the one which has been considered, and it descrves more detailed treatment, since it has had the support of eminent economists and logicians. We are told that, even if experiments are tried by modern govermments, 
they are tried under such conditions as to have no scientific value and to permit of no convincing conclusions. This was the view of John Stuart Mill, at once a great logician and a great economist, and it has been accepted by many, if not most, of his successors. Mill, after enumerating the four different methods of experimentation which are possible, concludes that no one of them is adapted to the social sciences. Take, e.g., the methods of differences and of concomitant variations. In order to apply the former we must have two instances which tally in every particular except the one which is the subject of inquiry. In order to apply the latter we must have a series of phenomena varying together. ${ }^{3}$

To prove the inapplicability of the method of differences, Mill takes the example of a protective tariff and shows that it would be quite impossible to find two nations which are exactly alike in every respect excepting only in the presence or absence of such a tariff. ${ }^{4}$

3 John Stuart Mill: A System of Logic, 9th edition, 1875, Vol. I, pp. 448-471.

4 l. c., Vol. II, p. 472. 
The method of concomitant variations he thinks equally impossible, because every attribute of the social body is influenced by innumerable causes. Hence the changes are the effects, not of a single cause, but of the combination of many causes. ${ }^{5}$

We may concede the difficulty of applying the method of differences to test the effect of a protective tariff upon the general wealth of nations, and yet recognize the possibility of experiments if applied in a different way. It will be noticed that the question which Mill asks is extremely vague. He inquires whether or not a protective tariff is "favorable to national riches." That very question itself requires a further explanation. What do we mean by "national riches"? Do we take into account the mass of wealth, or also its distribution, and if we take account of its mass only, do we mean the total mass or the wealth per capita? We might conceivably have two states each of $30,000,000$ inhabitants, with an average wealth of $\$ 1,000$ per inhabitant or a total of $\$ 30,000$,000,000 . Let us suppose that at the end of the experimental period one of our states sl. c., Vol. II, p. 475. 
has a population of $45,000,000$ with the same per capita wealth as at the beginning, or a total of $\$ 45,000,000,000$, while the other has the same population as at first, but an average wealth of $\$ 1,500$ per capita, which would give the same total as that of the first state. Shall we conclude that the two states are equally well off, or shall we award the prize to the one which has the larger population and a smaller per capita wealth, or to the other one? Apart from the vagueness of the question, it is clear that the tariff is only one of the many factors determining the wealth of nations, and that, moreover, the effect of the tariff in one country must depend, not simply upon factors affecting that country, but also upon the tariff policy of other countries with which it trades. In other words, the example taken by Mill is of such a complicated character, that it could hardly be solved by the experimental method in one of the simpler sciences permitting of a full laboratory equipment. In chemistry, e.g., we should have an analogous case, if we were to ask, whether oxygen or hydrogen is the more useful element in the economy of nature. In order to apply the experi- 
mental method to economic questions, we must apply it as it has been applied successfully to the natural sciences. Now the greatest achievements in science have been attained, not by putting such general questions as that instanced by Mill, but by making the questions more and more specific, taking into account only a limited number of phenomena at a time.

The science of medicine illustrates in its history this tendency of scientific method. The skilled physician no longer asks for the general effect on the total well-being of the human body of certain drugs or a certain diet, but he tries to isolate his phenomena and study them in detail. For example, people often ask the questions, Is it better to drink alcoholic liquors or to abstain? Is it better to eat both meat and vegetables or to chew vegetables and eschew meat? Now it is clear that general observations are not absolutely convincing on these topics. The friend of alcohol can produce plenty of instances of drinkers who have lived to a hale and hearty old age, and plenty of abstainers who have died young. The same can be done with regard to a meat diet. But the physiol- 
ogist can study the question of alcohol in detail and, by experimentation, can ascertain what its effects are upon digestion, upon the tissues, etc., and he can thus isolate its effects from the many other effects which go to produce the total well-being of the body. ${ }^{6}$ Even in the practice of medicine physicians are tending more and more to give but a single drug at a time, in order the better to observe its effects, instead of a combination of drugs compounded with a view to producing general results.

If the question which the economist desires to have answered is properly framed, and if he has at his command proper observations as to results, then it is not necessary to postulate a number of different nations exactly alike in all particulars but one, any more than in studying the effect of drugs upon human beings it is always necessary to have a number of patients exactly alike. By applying or not applying a certain agency to the same person, we may often observe the effects of the policy with all of the certainty which

6 As an example of this method, see Physiological Aspects of the Liquor Problem, 2 vols., Houghton, Mifflin and Company, 1903. 
goes with a laboratory experiment. The same is true of nations, where most of the circumstances may be assumed to continue essentially the same throughout a considerable period, and where allowances can be made for such changes in circumstances as are inevitable. Thus, while it may well be impossible to trace the effect of a protective tariff upon the general wealth of the country, it is not so difficult to trace its effect on the separate factors entering into that wealth, such as the distribution of wealth between different classes, the prices of protected commodities, the conservation of the natural resources of the country, the growth of monopoly, etc.

Mill's prepossession in favor of the deductive method may not unreasonably be attributed to the state of the natural sciences in his day. It certainly seemed at that time as if astronomy, the most ancient and dignified of the sciences, had reached the enviable position of commanding general principles, which enabled it to predict by means of deduction what would happen in particular cases. It was not unnatural to assume that the sister sciences would in succession enjoy a similar authority 
and be able to promulgate, ex cathedra, a few general laws, from which details could be deduced. But the progress of science has taken a course which could hardly have been anticipated. Astronomy itself has been applying observation on a scale which could not have been imagined fifty or sixty years ago. The use of photography and of the spectrum analysis, in such studies of the composition of the sun as those which have been made by Dr. Hale and his colleagues in the Mount Wilson Observatory of the Carnegie Institution of Washington, have opened up entirely new fields of investigation and have given us facts of which deduction would be clearly incapable. Geology and zoölogy, which were formerly, in the main, sciences of observation, have become experimental. The geologist no longer contents himself with observing the stratifications of the earth's crust, and drawing conclusions from them. In the geophysical laboratory he actually fuses rocks and reproduces in his microcosm the process by which the earth's crust was formed. The zoölogist is able, as in the Laboratory of Experimental Evolution of the Carnegie 
Institution, to study the laws of heredity under controlled conditions.

Such changes as these are doubtless due to the fact that the apparatus of experimentation has attained a range and perfection formerly unknown. The methods by which the great medical discoveries of recent years have been made are familiar illustrations of this progress in our instruments of observation.

If economics is to profit by the example of the natural sciences, it must take account of what they have done since the days of John Stuart Mill. Instead of treating deduction as its goal, it must consider it as its starting point. Deduction can undoubtedly give us certain general laws based upon our inner consciousness of motives and impulses, but these, by their nature, must be general and true in proportion to their vagueness. The next step beyond deduction must be description and observation, and this phase has been amply illustrated by the great contributions to our monographic literature made by the historical school in Germany, and by scholars in other countries who have been more or less 
inspired by it. Purely descriptive work, however, whether historical or statistical, is not the goal of science. Our next step is to apply experimental methods, that is, not merely to describe, but first to analyze, and then to apply such methods as that of concomitant variations, and to measure the results as far as they are capable of numerical expression.

In claiming for economic phenomena the value which we attach to experimentation, it should be understood that we are not dealing with mere observation as applied by the geologist, or the astronomer, or the zoölogist. Most economic experiments, though they may not be made with an avowed scientific purpose, are yet made on the basis of a definite theory, and the fact that this theory often enjoys the complete confidence of the legislator does not alter the fact that it is in its essence experimental, inasmuch as its results are problematical. The zoölogist, who observes animals in a state of nature, studies variations which occur without any reference to any theory that he may have in his mind. But in social phenomena, especially in modern countries, the variations are 
always due to a deliberate purpose, and that purpose is generally based, either consciously or unconsciously, upon a certain social or economic theory.

Francis Place, e.g., thought that the excesses of trade unions were due to the restrictions of the law and that, if these were removed, industrial peace would prevail. His agitation brought about the repeal of the English combination laws in 1824, but the great increase in strikes and other disturbances which promptly followed, completely disproved his theory.

Some thirty-five years ago many economists thought that the alternating demand for gold and for silver which would result from intermational bimetallism would keep the ratio of exchange between the two metals constant. As the agreement necessary to such a policy could not be carried into effect, our country endeavored to raise the price of silver by increasing the governmental demand for it, and first the Allison Act of 1878 and then the Sherman Act of 1890 were passed with this theory in view. The steady fall in the price of silver, in site of that demand, went far towards proving the limitations of the 
bimetallic theory. The so-called "AntiTrust Law" of the United States, which is being so much discussed at the present time, is based upon the theory, commonly accepted from Adam Smith down to the last quarter of the nineteenth century, that free competition is the best cure for the abuses of trade. Many are now reaching the conclusion that our experience with that law is showing up many important limitations upon that theory.

Not only do economic experiments rest, as a rule, upon some hypothesis, but they often rest upon the theories of the economists themselves, which, though they may be derided or ignored in the beginning, slowly filter from the text-books through the magazines and newspapers into the popular mind and influence public opinion, at times, in the next generation. The economist has at least one attribute of divinity in that his mills, like those of the gods, grind slowly. In 1882 Jevons wrote: "If it can be shown by unquestionable statistics and unimpeachable evidence of scientific men that such working with phosphorus leads to a dreadful disease, easily preventable by a small change of 
procedure, then I hold that the Legislature is prima facie justified in obliging the man to make this small change. The liberty of the subject is only the means towards an end; it is not itself the end." "i But thirty years elapsed before the Congress of the United States passed the phosphorus bill, and even then prominent members of both parties opposed it, not on practical grounds, but for the purely abstract, psendo-philosophical reasons referred to by Jevons.

John Stuart Mill advocated taxing the unearned increment in the value of land as far back as 1848. ${ }^{\circ}$ Though some German cities began to tax this increment in $1905,{ }^{\circ}$ and indeed, the same principle had been applied in the German colony of Kiao Chau in 1898, many of Mill's countrymen appeared to be quite unconscious of it, sixty years after he had enunciated it. Thus, when the parliamentary agitation

7 W. Stanley Jevons: The State in Relation to Labour, 1882, pp. 12-13.

8 First edition of Principles of Political Economy, Vol. II, 1848, p. 361.

9 See article by Robert C. Brooks on The German Imperial Tax on the Unearned Inerement, Quart. Jour. of Economics, August, 1911, pp. 682-709. 
began which led to the enactment of the law of 1910, the proposition impinged upon the Tory mind with the painful shock of a new idea. 


\section{CHAPTER II}

\section{Some Questions of Methodology}

These illustrations of some of the topics to which the experimental method may be applied, suggest the desirability of answering two more general and fundamental questions which lie at the very basis of all economic study. One is, What is the nature of the material with which the economist has to deal? The other is, What kind of results should he try to obtain?

As regards the first question, we should recognize that the material is not homogeneous. Much confusion results from a failure to realize this fact. As hinted by Professor von Schmoller, ${ }^{1}$ our material is drawn from three distinct kingdoms. First of all, we have the human mind with its impulses and wants. This is the element emphasized by the deductive school. Then we have the physical world, or what we call in general nature, that world which we

1 See his article: Volkswirtschaft, Volkswirtschaftslehre und -methode. Handwörterbuch der Staatswissenschaften, 3d edition, 1911, Vol. VIII, p. 457. 
know by our sense impressions. ${ }^{2}$ Finally, we have the social organism, including laws, institutions, and customs, which we may be said to know partly through our inner consciousness, inasmuch as we ourselves participate in the social life about us and share the feelings of our fellow men, and partly by indirect sense impressions derived often through the medium of writers of books, or through oral tradition. In this case, the minds of other persons serve as the medium through which the facts of the outside social world reach us. This combination of factors may be illustrated by almost any familiar economic phenomenon, such as a strike. In the great anthracite coal strike of 1902, the course of events was influenced not only by the simpler economic impulses, such as the desire of the miners to get as much as possible, and of the employers to pay as little as possible. It was also conditioned by purely geological data, such as the thickness and dip of the seams of coal, which determined different methods of payment in different parts of the coal fields.

2 See Karl Pearson: The Grammar of Seience, 3d edition, 1911, Chap. II. 
Finally, it was influenced by social institutions such as the trade union with its discipline and its traditions, by the joint stock company with its legal rights and inner organization, by the law of the land, which forbade violence, by the press, and by the moral pressure of the commission appointed by the President, etc.

Now it is clear that, while economists have to study the resultant of a combination of three elements, each of them is subject to influences of its own. The psychical element is influenced by education, by religion, by race, etc. The material world is influenced by geological processes, by the seasons, by the operation of evolutionary forces, etc. The social world is influenced by laws, by diplomatic and military events, in short, by what we call history. The economist must, therefore, look for uniformity, not so much in the general result as in the individual elements which enter in to make that result. $\mathrm{He}$ is, in a sense, like the meteorologist, who has to study that familiar but very complex phenomenon which we call the weather. This obvionsly depends upon a number of entirely distinct things. It depends pri- 
marily upon the position of the earth with reference to the sun, but, beyond this fundamental astronomical fact, we also have the complicated physical and chemical conditions on which depend the density of the atmosphere, the movements of the air, the temperature, the currents of the ocean, and other things. Now it is futile to expect to predict the weather of any day from the weather of the past, excepting as we may indulge in such obvious prognostications as that it will be hot in summer and cold in winter. But the meteorologist knows the tendency of each of the elements taken separately, and by studying their combination at a given time he may predict with a fair degree of approximation what the weather is likely to be in the immediate future.

What kind of results are we as scientific economists to aim at in our study of this material? It may be best to approach this subject by first asking what we do not aim at. If economics is a science, we are not content with mere description of economic processes, however great the utility of description as a preliminary phase of our work may be. Nor can we stop at the nar- 
ration of economic events, or at a classification of economic elements, or even at their statistical enumeration. Our aim is to obtain those generalizations commonly called scientific laws. According to a recent English writer on this subject, law in the scientific sense is a "description in mental shorthand of as wide a range as possible of the sequences of our senseimpressions." "3 Practically the same idea is expressed by a recent German author witl special reference to economics, when he says, that the task of the economist is "Beschreiben unseres Systemes und seiner Bewegungstendenzen. . . . . Die Sätze, aus denen die Beschreibung besteht, nennen wir dann 'ökonomische Gesetze.' , ,

Both of these authors imply that we are concerned with changing, not stationary, phenomena. "It deserves special note," says Pearson, "that the sequences with which we are dealing are all reducible to descriptions of motion, or of change.", We must, therefore, distinguish scientific

3 Karl Pearson, l. c., Chap. IV, p. 112.

4 J. Schumpeter: Das Wesen und der Hauptinhalt der theoretischen Nationalökonomie, 1908, p. 29.

5 1. c., p. 133. 
laws from so-called statistical laws, such as "Engel's law" regarding the items of expense in family budgets. These differ from scientific laws in that they record, as far as they really do record the truth, a state of things and not a sequence. ${ }^{6}$

We must also distinguish between economic laws and so-called historical laws. These, to be sure, record changes, but they deal with such a complex mass of events that any exact duplication of them is in a high degree improbable and, indeed, has never been experienced. At best, we may postulate certain general and indefinite tendencies such as that expressed by Aristotle in his famous cycle of governmental changes. In order to obtain scientific laws, that is to say, sequences which shall have any high degree of uniformity, we must isolate our factors and consider by themselves the sequences which apply to each one. We must thus eliminate, either by actual experiment or by the application of the scientific imagination, the many other factors which, when combined, constitute the phenomena as they present themselves to us in real life.

${ }^{6}$ On statistical law compare von Schmoller, l. c., p. 485. 
The analysis of phenomena is particularly important in economics, on account of the difference in the three principal elements which, as explained above, enter into our field of study, and the unequal part which they play in its different divisions. Though all three occur in combination in practically all of the different topics commonly treated in a text-book of economics, it seems as if the material world and its laws were particularly prominent in the subject of production. The law of diminishing returns, e.g., is a factor of nature rather than of the mind of man. The social element, on the other hand, determines to a large extent the distribution of wealth. For instance, the legal status of labor, the legal privileges of, or restrictions on, capital, the system of land tenure, the incidence of taxation, etc., all play a prominent part in distribution. In consumption, finally, the will of man seems to be the important factor. Whether, e.g., a nation will spend its surplus income on liquors and tobacco, or on jewelry and fine clothes, or on houses, or on babies, will

i See von Schmoller, l. c., p. 485. 
depend upon its psychology, though this may be affected secondarily by environment and social institutions.

There is ample opportunity for the application of the experimental method in studying all of these standard subjects in economics. But there is one topic to which no other method can be successfully applied. I refer to what we may call economic pathology. This may be defined as a condition in which organs are diseased, that is to say, in which they fail to perform their normal functions. Now in economics this may mean: (1) Some form of human degeneracy, which in turn may be either physical or mental. Examples of the former are disease, sterility, physical weakness. Examples of the latter are indolence, dishonesty, immorality, drug habits. (2) A pathological state of our economic system may result from the deficiencies of nature, such as the exhaustion of the soil or other natural resources, the denudation of woodlands, the lack of rainfall. These are sometimes the results of bad legal institutions, and therefore indirectly caused by man, but they are primarily physical, and in many cases, as 
in changes in humidity, they seem to be attributable mainly to physical causes. (3) The disease may be in the social system. China, e.g., has vast unused resources, and an intelligent, industrious population, but bad government has retarded the utilization of its powers.

Now mere generalization with regard to the economic man gives us no help in studying economic pathology. We must get our facts at first hand. We cannot draw from our inner consciousness the causes of economic disease, any more than we can discover by metaphysics the microbes that infest the human body.

The idea of economic experimentation is not in itself new. Newmarch referred to it in his address as president of Section $\mathrm{F}$ of the British Association for the Advancement of Science as long ago as $1861,{ }^{8}$ and actually claimed that economics had then reached the experimental stage. Jevons, in 1880, wrote an essay on "Experimental Legislation and the Drink

8 Journal of the Royal Statistical Society, December, 1861 , pp. 451-467. See quotation from Newmarch's address, given by Menry Ludwell Moore: Laws of Wages, 1911 , p. 170. 
Traffic," in which he advocated the enactment of laws applicable to limited areas only for the express purpose of testing them. ${ }^{9}$ Similar views were expressed by him in his book on "The State in Relation to Labour." Professor Ely, after quoting the plan of Jevons just referred to, stated that the German historical school "claimed that the whole life of the world had necessarily been a series of grand economic experiments, which, having been described with more or less accuracy and completeness, it was possible to examine. " 10

A decade later Keynes conceded the possibility in certain cases of economic experimentation $;{ }^{11}$ and still more recently Professor von Schmoller, an economist who combines in a rare degree philosophical training, historical knowledge, practical experience in legislation, and familiarity

9 This essay was originally printed in the Contem. porary Reriew, for February, 1880. It was reprinted in Methods of Social Reform, 1883, pp. 253-276.

10 Richard T. Ely: The Past and Present of Political Economy, Johns Hopkins University Studies, Series 2, No. 3, 1884, p. 45.

11 John Neville Keynes: The Scope and Method of Political Economy, 2d edition, 1897, pp. 188-190, and 275-279. 
with economic literature, in summarizing the latest conclusions of a long life, has expressed his general coneurrence in these views of Keynes. ${ }^{12}$ Nor is it uncommon in more popular writings to find legislation referred to as experimental. The Hon. Samuel W. McCall, e.g., in a recent article says that the people of Oregon "are heroically subjecting themselves to political vivisection in the testing of governmental experiments.' ${ }^{13}$

We seem to be confronted here with a case in which the same word is used by different authors with quite different connotations. Newmarch, Jevons, and Congressman McCall were apparently thinking of experiments in social policy, more particularly in certain forms of social legislation, rather than experiments designed to test or discover general economic laws, and it is significant that Jevons' most original contribution to economic science lay in the field of economic abstraction. The point of view of the early writers of the German historic school seems to differ

12 See article Volkswirtschaft, Handwörterbuch der Staatswissensehaften, $3 \mathrm{~d}$ edition, Vol. VIII, p. 480.

13 Atlantic Monthly, October, 1911, p. 459. 
even more widely from that which is presented here. Many of them not only did not expect to discover general economic laws by the historical method, but denied that such laws existed. The aim of Knies, who is commonly considered the founder of this school, seems to have been rather to trace laws of historical development, while Roscher, one of its most prolific and widely read representatives, used history more for the purpose of illustration than of proof. It may be said in general that the vast and valuable monographic literature brought into existence during the past half century under the stimulus of this school of thought emphasizes the historical rather than the theoretical element. As Professor Amonn says:

Die methodisch-kritischen Ansichten der historischen Schule in bezug auf den logischen Charakter einer Wissenschaft ron der Volkswirtschaft führen in ihren extremen Formulicrungen und deren letzten Konsequenzen zu einer völligen Negation der theoretischen Nationalökonomie und zur Proklamierung der Alleinberechtigung einer rein historischen Betrachtungsweise, d. h. es wird geleugnet, dass es ein theoretisches Erkenntnisobjekt in bezug auf die Volkswirtschaft überhaupt geben könne, und 
lediglich ein solches mit historischem Charakter anerkannt. ${ }^{14}$

Similarly a recent French author, in referring to the publications of the historical school, says:

Les institutions du moyen age et de l'antiquité, les doctrines anciennes, l'histoire sociale, la statistique, la description de l'organization économique des nations modernes forment l'objet essentiel de ces travaux. L'économie politique est comme fondue ou noyée dans l'étude des institutions et dans l'histoire économique. ${ }^{15}$

Keynes and von Schmoller seem to refer to the experimental method as a means of obtaining scientific laws more in the sense of this essay, but to treat it as on the whole exceptional and limited in its scope.

Within recent years, however, not a few authors have begun to apply, each in his own field, the method here advocated. Mathematical processes and notation are used by many of them, such as Professor Irving Fisher, Professor H. L. Moore, and

14 Alfred Amonn: Objekt und Grundbegriffe der Theoretischen Nationalökonomie, Wiener Staatswissenschaftliche Studien, 10 Band, Erstes Heft, 1911, p. 44.

15 Charles Rist in Gide et Rist: Histoire des doctrines économiques depuis les Physiocrates jusqu'à nos jours, 1909, p. 446. 
the group of Italian economists referred to by him in his Laws of Wages. ${ }^{16}$ That a similar method may be used without mathematical apparatus and in a more strictly historical subject, is shown by Dr. Woods, who has even invented the term "historiometry" to designate it. ${ }^{17}$ The purpose of the present study is to emphasize three considerations.

1. The need of a systematic and concerted extension of this method. It involves collecting a large number of data in order to distill from them a few generalizations. The individual investigator is usually able to command but a limited field, and even then is often obliged to draw his material from different places and periods with loss of accuracy in his conclusions. We need more team work. We need a closer co-operation between the universities, the governments, and the various societies and institutions devoted to economic research. In short, we need the principles

16 l. c., pp. $173,174$.

17 See Frederick Adams Woods: Mental and Moral Heredity in Royalty, 1906. A New Name for a New Science, Science, November 19, 1909 ; Historiometry as an Exact Science, Science, April 19, 1911. 
of "scientific management" applied to economic science.

2. The scientific value of historical facts, even when they are not expressed statistically. Mathematicians have hitherto been the most effective exponents of the experimental method, and our ideal must be to express in numerical form the generalizations of economics, since no "short hand," to use Professor Pearson's expression, is so concise and so precise as that of mathematics. At the same time it is only within a very recent historical period that we have had any extensive body of statistics to draw upon, and even now it must be conceded that this handmaiden of science has been known to do her work in a slovenly fashion and to make a show of perfection hardly warranted by the reality. In undue reliance upon inaccurate figures even mathematicians are tempted to push the refinement of their formulæ beyond the accuracy of their data. We need to bridge over the gap between the history of the past with its broad but fairly well-authenticated facts, and the statistics of the present with their elaborate but often confusing and misleading detail. 
SOME QUESTIONS OF METHODOLOGY

3. The importance of utilizing the great amount of economic material contained in the history of our own country. An attempt will be made in the following chapter to point out some of the peculiar advantages afforded by the United States for this kind of research. 


\section{CHAPTER III}

\section{Economic Experimentation in the United States}

One of the most salient facts in the early history of the United States is the great importance of, and the attention paid to, economic interests. Such interests are potent in the history of all nations, but if we compare our country with Europe since the Middle Ages, we must recognize that there are two forces very prominent in determining the history of Europe, which were absent from our country. One is dynastic ambition, which could not exist in a country without kings or princes. The other is religious zeal. It is true that the desire to worship God in their own way led the Pilgrims first to settle in New England, but it is fair to say that we have never had in our country those great disturbances which have been caused by the wars of religion in Europe. Thus in the very nature of the case economic considerations were predominant. 
Another factor entering into European history, though it has existed in our country, has also played a much less important part. I refer to racial prejudice. It is true that we have not been free from this curse, but fortunately we have been thus far spared wars of races and great racial antagonisms, such as are constantly arising to pit the Teuton against the Latin or the Slav or the Magyar in Europe.

Economic forces have had a wonderfully free play in our country on account of its newness and the consequent absence of institutions and traditions which resist a change in older communities. Hence if we look at many of our early laws, such as the Massachusetts Body of Liberties, we shall see that they deliberately adopt certain economic ideals which they endeavor to make the rule of conduct in the commonwealth.

In New England generally feudal land tenures were avowedly discarded in favor of the simpler freehold. The rule of primogeniture was abandoned, and instead a system was adopted under which, in case of intestacy, the land was divided among the children, the oldest in some cases 
merely having a double portion. As clearly stated by Governor Talcott, this was done in order to encourage the younger sons to stay upon the land and cultivate it. ${ }^{1}$

If economic questions were prominent in the settlement of our country, they have gained in prominence throughout our development. Most of our political questions have turned upon economic interests or economic ideals. I need but refer to the slavery question with its many ramifications and complications, resulting in the Missouri Compromise, the Fugitive Slave Law, the Compromise of 1850, and the Civil War, or consider the debates about the United States Bank, the endless controversies about the tariff, the currency, the public lands, and, more recently, regarding immigration, the organization of labor, and the regulation of corporations, to show what an important part economic questions have played in our internal development.

Other countries have, it is true, their own economic problems which they are trying to solve by legislation. But the

1 C. M. Andrews: The Connecticut Intestacy Law, Yale Review, November, 1894, p. 268. 
United States has the transcendent advantage as an experiment station of being composed of a group of States, each of which legislates upon a very large range of topics. To a certain extent it shares this peculiarity with other modern federal states, whose constitutions are more or less modelled upon ours, such as the Swiss Republic, the German Empire, Canada, the Australian and South African commonwealths. But we have the advantage over the British colonies of a longer history, and over the European nations of fewer historical institutions and racial antagonisms, which interfere with the strictly economic effects, while, as compared with any one of these states, we have the advantage of a larger number of units and therefore of a broader application of the method of differences. Thus we have in the framework of our government the very conditions which Jevons would have introduced into England, in order to test experimentally the operation of different kinds of liquor laws. ${ }^{2}$ Economically our country may be likened to a hospital with fifty general wards, each under separate medi-

2 Jevons: Methods of Social Reform, p. 265. 
cal direction, and a large central ward for certain selected cases, while a number of outlying pavilions and annexes under still different systems are loosely connected with the central institution. What an opportunity this offers the economist who will carefully study the results of the different kinds of treatment!

It is not only in official experimentation through legislation and administration that our country is rich. It has also been the happy hunting-ground of social Utopias. In many cases it has been their burying-ground as well. Many of these communities, such as the Mormons, the Shakers, the Perfectionists, etc., have had a religious or moral ideal. Others, like Brook Farm, New Harmony, the shortlived Ruskin Colony, the Fairview Colony of Single Taxers, have been based upon social or economic ideals. Each of these communities represents on a small scale a voluntary experiment in some department of economics. The ease with which such Utopias spring up in our country is illustrated by the fact that within two years of the publication of Looking Backwards more than 50 Bellamy Clubs with a mem- 
bership of about 3,000 are said to have been established in California alone. ${ }^{3}$

The organization of ideal communities, which was so popular in the first part of the nineteenth century, seems to be succeeded in the first part of the twentieth century by an equally enthusiastic activity in the formation of societies designed to promote some reform in our public policy. Some of them relate to taxation, some to the regulation of the liquor traffic, some to labor legislation, some to conservation, some to land tenure. Each one is a stimulus, urging the legislatures to test by actual experiment the ideas for which they stand.

Apart from the idealists, we have a great mass of experiments tried in the self-interest of those who themselves are engaged in production. Our business men and lawyers have been peculiarly ingenious in evolving new forms of industrial organization. Our public service corporations are testing new methods of adjusting their charges, until the study of rates has become almost a science by itself. ${ }^{*}$

3 Ira B. Cross: Co-operation in California, American Economic Review, September, 1911, p. 536.

4 J. Maurice Clark: Rates for Public Utilities, American Economic Review, September, 1911, pp. 473-487. 
Likewise the wage receivers are trying all kinds of methods of improving their own condition. Every strike may be said to represent an experiment relating directly to the important question of economic theory: what determines the rate of wages.

In all of this experimentation we have the great advantage in our country of carrying it on under conditions described by that farorite phrase of the economist, "other things being equal." By this I do not mean that we have been able to try different things under absolutely identical conditions, such as might be created in a laboratory, but, as compared with the conditions under which economic history has developed in other parts of the world, we may claim for our own country that these experiments have been conducted under three exceptionally favorable conditions:

1. They fall within a limited period, so that no great or fundamental changes have taken place in the cultural standards of civilization or the mores of the people such as characterized the change from the medirval to the modern period in Europe.

2. The experiments have been carried on within an area of political uniformity, 
so that, although there are great differences in latitude and longitude, climate and soil, between the different parts of our country, yet the general legal and social environment is very nearly the same.

3. These experiments have been carried on among a people, which, if not homogeneous in its ethnic makeup, is at least remarkably uniform in its heterogeneity. Our country is like a good mince pie; any one slice contains many ingredients, yet specimens from different parts of the whole are made up of nearly the same elements, varying mainly in their relative prominence. Thus everywhere we have the common basis of the English language and, with the exception of Louisiana, of English law. Everywhere too, we have a greater or less admixture of different European races, of Africans, and occasionally of Mongolians. While, of course, the percentage of the different races varies widely in different parts of the country, it cannot be said that any one race except the Anglo-Saxon exerts in any section a purely racial predominance upon our institutions. ${ }^{5}$ Even in the South, in com-

5 The word Anglo-Saxon is to be taken in its broadest 
munities in which the blacks outnumber the whites twenty-seven to one, the institutions are essentially Anglo-Saxon and not African. While, therefore, we have not the absolute control over our conditions that is enjoyed by the chemist, and while the elements are vastly more complicated than those entering into the ordinary laboratory experiment, we have conditions relatively favorable for obtaining good results.

The temptation is strong to enumerate, at least in part, some of the many fields of economic experimentation which are to be found in the history of the United States, but to do so at length would expand a chapter into a monograph and is, therefore, out of the question. Some of these departments of study, such as those relating to currency, to prices, to the rate of interest, have already yielded valuable results to the investigator. Some of the more practical questions, such as those relating to land tenure and the methods of agriculture, as well as the purely govern-

sense to cover tre whole Low German stock, without any reference to the relative strength of the English and Dutch element in New England institutions. 
mental questions involved in taxation and the management of public debt, still remain to be studied intensively, in spite of a considerable amount of work already put upon them. Less, on the whole, has been done with the problems relating to labor, methods of remuneration, the rates of wages, the efficiency of labor, etc. We have tried many experiments in this department of economics. We have had free labor, indentured labor, and complete slavery. We have made a sudden transition from slavery to freedom, so sudden as to bring with it many undesirable results, but perhaps for that reason the more interesting as an economic experiment. In the application of free labor we have likewise had experiences of great value. We have had labor both organized and unorganized, native-born and foreign, and we have had trade unions of many types and representing many stages of development. We have tried many systems of wages. We have developed, particularly in the South, various methods of applying labor to land, which represent gradations ranging from free tenancy to a system verging on peonage. 
Though considerable attention has been given to this topic, many of its complicated problems have been barely touched upon. The economist often inquires about the effect of labor on production, but he seldom asks, "What is the reaction of wealth upon the efficiency of labor?"

According to the observations made by Mr. Frederick W. Taylor, it does not pay to increase wages too rapidly. Indeed, he has endeavored to give a mathematical expression to the possible rate of economical increase and says that, if wages are increased up to 60 per cent beyond the wages usually paid, this increase tends to make the men more thrifty and better in every way, but that, when the rate goes beyond 60 per cent, many of them tend to work irregularly and to become more or less shiftless, extravagant, and dissipated. ${ }^{6}$

Economists have done little in the study of this phase of the labor problem, since Ricardo laid down the pessimistic view that the population tends to increase with an increase in wages. Yet it is a commonplace that, while an efficient population

6 See F. W. Taylor: The Principles of Scientific Management, 1911, p. 74. 
may be seriously handicapped by the " "niggardliness of nature," a country with large natural resources may be likewise held back, because the inhabitants either will not or can not utilize them, or because they do not apply sufficient intelligence and energy in international competition.

It is a matter of common observation that wealthy families in our country often contain a number of parasitic members, that is, members who derive a large income from society without rendering any appreciable economic or public service in return.

Mr. Andrew Carnegie gives expression to a common view when he says: "There is nothing so enervating, nothing so deadly in its effects upon the qualities which lead to the highest achievement, moral or intellectual, as hereditary wealth." But we have no figures to tell us with any accuracy how numerous these drones are, or what proportion they bear to the more useful members of the same families. It seems very probable that the public have an exaggerated notion of their vices, because, as Dr. Woods points out, "the vices of the

7 Andrew Carnegie: The Empire of Business, 1902, p. 126. 
aristocracy are always made the most of by the polychrome daily press," $"$ and in the absence of an aristocracy, multimillionaires furnish good copy. But even granting that we know a little of their moral shortcomings, we know practically nothing of their economic efficiency. Little account is made on the one hand of the many men and women of means who live conscientious, industrious lives, devoting themselves to some form of production or of public service; or, on the other hand, of those whose energies are dulled by the possession of a competency, and who, without being actually vicious, are mere ciphers as far as any economic usefulness is concerned. Yet we ought to have reliable facts, if we are to judge correctly of the reaction of prosperity on the human mind, and of the conditions which determine it. Intensive studies of heredity in families, such as those made by Sir Francis Galton in England and Dr. Frederick A. Woods and Dr. C. B. Darenport in our country, are of great value, but need to be supplemented by a study of the economic re-

81. c., p. 261. 
actions. In the case of animal life, the inherited characteristics are all-important, and the breeder can reasonably expect to utilize the good qualities of the parent in the offspring. But if cows had the power to deliberately choose a life of celibacy, we should find many a pedigreed Guernsey, with ancestors in the advanced register, chewing lrer cud in idleness on the hillside and yielding no milk whatsoever, just as we often find sons of distinguished parents displaying real ability, when put to some academic test, and yet, for lack of proper incentive, doing nothing to make their lives either useful or distinguished.

Our country should give exceptional facilities for studying parasitism in the "leisure class," because here wealth is not subject to the social pressure of the feudal system, inherited in the older countries of Europe from the time when wealth meant land ownership, and land ownership of necessity involved public duties. Many of this class walk our streets, eloquent but unconscious arguments for socialism, terrible examples for the moralist, living texts for sermons, rich material for the problem novelist, but still comparatively 
neglected by the economist, the sociologist, and the statistician. We gather the budgets of working men but not of club men; we collect the statistics of involuntary unemployment but not of voluntary idleness; our study of social conditions on the East Side has not been extended to the West Side. Yet it is obviously of the greatest importance to a nation, as it is to a cattle breeder, to reproduce and utilize the strong and dominant types, and we must know why so many of these members become atrophied, if we would understand the causes of national decadence, the great and perennial question of history as well as of practical politics.

Parasitism is, however, but a part of the general subject of economic pathology, which has been altogether too much neglected by economists in the past. Or, if we pass beyond the strictly economic questions to those broader questions of social policy, what vast materials have we in our country bearing upon the mixture of races. What a splendid opportunity to test the theories of the philosophical anarchist, who holds that the ills of society are due to the law, and who may study in the history 
of Alaska the effect of allowing a commonwealth to grow up almost without law.

It is not necessary, in this brief survey of the opportunities which our country offers for economic induction, to make an elaborate enumeration of topics or to show in detail how the material may be secured. Attention should, however, be called in fairness to some of the defects in conditions which make laboratory methods difficult, and which must be taken into consideration before any piece of work is undertaken.

In the United States experimentation is constantly interrupted by the power of our courts to nullify laws. Thus experiments may be overthrown on grounds which are quite extraneous to their essence. It is as if a biologist were to suddenly find his laboratory invaded and wrecked by an over-zealous anti-vivisectionist.

The economist has the further disadvantage that the subjects of his study and experiment are men like unto himself, with opinions, emotions, and voices. Hence every experiment is accompanied by a babel of sound, which seems to confuse the whole subject. The physiologist, working 
in his quiet laboratory, is apt to think the very subject-matter of economics ill adapted to scientific study. If the human body were the seat of a republic in which all of the microbes that infest it and the ferments that endanger it were vocal, the investigator would have to put wax in his ears to keep lis mind free from disturbance. Imagine the bacilli of consumption and of typhoid holding periodical elections to see which should for the next four years control the state of health of the patient, with a lot of insurgents in the shape of pyamia and dyspepsia striving, if not to govern, at least to hold the balance of power!

Another equally serious defect lies in the inadequacy of our records. The amount of economic material buried in the archives of our States is enormous. The material buried in the records of corporations, of labor unions, of voluntary societies, may be even greater. The mere index of State economic documents which is being compiled for the Carnegie Institution of Washington fills a portly quarto for each one of the older States. The cream of contemporary evidence available for the Docu- 
mentary History of American Industrial Society, recently published by Professor Commons and his collaborators, fills eleven volumes. But in spite of this vast material, we still have to contend with the imperfection of many of our records and with the difficulty of accurate mensuration. Professor Dewey, in his able presidential address delivered before the American Economic Association in 1909, enlarged upon the inaccuracies of economic observation, and all serious economists must recognize the truth of what he then said. But it is the task of the economist to overcome difficulties, not to shrink from them, and he can best do this by helping his successors to obtain a trustworthiness in their material which is not always available for him. It is encouraging that the Federal authorities, and the State governments as well, are relying more and more upon trained economists to record economic facts in the form of statistical or monographic studies. But we should remember that such studies are not the only output of a governmental kind to which we must turn. Every law affecting economic relations must be treated as an experiment, the recording of whose 
results should be provided for in the law itself. How much futile discussion and how many errors would be avoided, if we were able from year to year to put our hands on the results of the operation of laws bearing upon economic relations! Just as modern hospitals not only provide physicians and nurses but also laboratories and records, so every legislature should have its economic annex, in which not merely the text of laws but also their results may be made available both for the legislature and for the student.

The conception of history as an economic laboratory is quite different from the common conception of economic history. History is in the main descriptive. It seeks to give us a picture of the past. If it goes beyond that, it seldom attempts more than to trace general causes, or to lay down a philosophy of history or a theory of historical evolution. The economic utilization of history is almost the antithesis of the economic interpretation of history, since the latter is seeking a law of history and the former, laws of economics. The economist undoubcedly owes a debt of gratitude to historians, and particularly to economic 
historians, for the material which they have put at his disposal, and the brilliant address on "Social Forces in American History," delivered in 1910 by the president of the American Historical Association, is an indication of the increasing interest which historians are taking in social and economic elements. The contrast, however, between their point of view and the economic point of view cannot be better illustrated than by quoting from this address. Professor Turner says that he has undertaken his survey for two purposes: "First, because it has seemed fitting. to emphasize the significance of American development since the passing of the frontier, and, second, because in the observation of present conditions we may find assistance in our study of the past." ${ }^{\text {"The }}$ economist, while fully appreciating the value and the necessity of studying history from this point of view, must yet go a step further and must use the records of the past as a means of disclosing the operation of economic forces.

9 Frederick J. Turner: Social Forces in American History, American Historical Review, Vol. XVI, No. 6, p. 225. 
The difference between description and science may be illustrated by an example taken from the history of physics. The lamp hanging in the cathedral of Pisa might be described in every artistic detail by a traveler. The history of the designer and the story of its construction might be toid in full, without adding in the least to our knowledge of physics. It took the mind of a Galileo, at once analytical and constructive, to recognize in the apparently meaningless oscillations of the lamp a constantly acting force, and thus to discover the law of the pendulum. So the economist must recognize beneath the events of history the constantly acting economic impulses in the mind of man.

This view of economic history as a series of experiments is not in conflict with the evolutionary conception of history. Indeed, it is really necessary to explain it rationally, for, unless we are willing to accept a blind fatalism, according to which history moves on without being controlled by human volition, we must recognize that what seems to us the orderly development of institutions is rational and orderly, precisely because men have been constantly 
trying new expedients and have deliberately retained those institutions and practices which stand the test of experience. The very expression, "survival of the fittest," implies in human history a constant testing of new variants, as it does in the animal world, with this difference, however, that in the animal world the changes are brought about by the so-called forces of nature, which is another way of saying that, like Topsy, "they just growed," while in history most of the changes have been produced by a conscious effort of the human mind to bring about results. This is none the less true, because few individuals at the time have a sufficiently broad grasp of what is happening and a sufficiently profound knowledge of the world to know whither they are tending.

Economic science, after a period of public favor in which its generalizations enjoyed considerable confidence, seems to have gone through two rather distinct phases. When it found itself unable to grapple with many of the problems of the day, it was derided as the "dismal science" by impatient reformers. More recently, 
since it has begun to interest itself more in practical questions, it seems to be enjoying a popularity, especially in the United States, which is not without its dangers. It attracts large classes in our universities; it is being studied in our theological schools and by our churches; large sums of money are being spent by our governments in the interest of economic investigations. The economist must be on his guard against allowing this present popularity to encourage dilettantism. Our age is growing more and more critical. The business world is applying rigorous tests to ascertain results. The educational world is studying methods of efficiency. The economist is liable to go through another period of discredit, unless he realizes that he must apply to his study the patience, the exactitude, the devotion to truth by which the great conquests of natural science have been obtained. He needs all of these qualities in a larger degree even than the student of nature, because of the long period through which his observations have to extend, and the great complexity of the phenomena with which he is dealing. But if he can apply these qualities in the reali- 
zation that the world of economic change is his laboratory, and that it is his task to interpret its lessons, he will have his reward, in helping to solve the great human problems which have vexed mankind since the dawn of history. 


\section{CHAPTER IV}

\section{The Pathology of Progress}

The world of nature, if left to itself, is generally in a state of more or less perfect equilibrium. Those plants and those animals survive which are best adapted to their environment; the others perish. Each species has its enemies which prevent any one of them from monopolizing the earth and which, in turn, are held in check by their own enemies. As soon as civilized man steps upon the stage, however, this harmony of nature is disturbed, and the intruder may be positively destructive of those forms of life which are not able to adapt themselves to him or to minister directly to his wants. A good illustration of this is given by Theodore Roosevelt, in his Hunting Trips of a Ranchman, with regard to the buffalo.

The most striking characteristics of the buffalo [he says], and those which had been found most useful in maintaining the speeies until the white man entered upon the seene, were its phenomenal gregariousness, . . . . its massive bulk, and unwieldy strength. . . . . Its tough- 
ness and hardy endurance fitted it to contend with purely natural forces : to resist cold and the winter blasts, or the heat of a thirsty summer, to wander away to new pastures when the feed on the old was exhausted, to plunge over broken ground, and to plough its way through snow drifts or quagmires. . . . .

But the introduction of the horse, and shortly afterwards the incoming of white hunters carrying long-range rifles, changed all this. The buffaloes' gregarious habits simply rendered them certain to be seen, . . . . their speed was not such as to enable them to flee from a horseman; and their size and strength merely made them too clumsy either to escape from or to contend with their foes. ${ }^{1}$

This is the first effect of civilized man, but not the last. The book in question was written over a quarter of a century ago, when the buffalo seemed to be on the point of extermination. Fortunately, as man becomes more enlightened, he begins to realize that, in his struggle for the supremacy over nature, he may carry the contest too far for his own good. We now find that, somewhat tardily, civilized man is trying to save from extinction the few scattered specimens of the bison that have survived, and even by skillful crossing to endow

1 Theodore Roosevelt: Hunting Trips of a Ranchman, 1885, pp. 244-245. 
domestic cattle with some of those good qualities of their wild cousins which have enabled them to cope successfully with the climate of the plains through so many generations. Thus the stage of domestication follows the hunting stage of civilization, and the crude and wasteful processes of natural selection are replaced by those of artificial selection.

Like Orlando in the Forest of Arden, civilized man begins the struggle for existence with a drawn sword and a threat.

He dies that touches any of this fruit Till I and my affairs are answered.

In time experience teaches him, in the the words of the Banished Duke, that

Your gentleness shall force More than your force move us to gentleness. ${ }^{2}$

The course of man's dealings with nature is paralleled in his dealings with his fellow men. Almost every new invention, almost every new process, creates a power which is susceptible of abuse, or leads to changes in conditions which may be injurious to certain classes or certain interests.

2 As You Like It, Act II, Scene 7. 
The pioneers of industry have much in common with the pioneers of the frontier. Even those improvements which seem altogether good may bring in some incidental evil, which, while not by any means counterbalancing the good, yet makes itself felt as something to be removed. A good example of this is seen in the homespun industry of some of the Scotch isles. The island of Harris has long been famous for the quality of its tweeds. The climate is, however, very wet, and the sheep have been so subject to disease that it has been the custom to rub them with tar and grease to protect them from the cold. More recently an improved breed of sheep has been introduced, which is able to resist the climate, but it is now found that the grease which protected the sheep also improved the quality of the wool, so that the newer fabrics are not as good as the old ones. ${ }^{3}$ This is a common experience, not only in the history of inventions, but in the history of man's efforts to introduce higher forms of economic life and a higher kind of civilization.

3 United States Consular Reports, November, 1909, p. 223. 
The most important step upwards from savagery is to substitute the law of contract for the law of conquest. But as soon as violence is put down, there is danger that the physical strength and the courage which were essential to existence in the ruder age will be lost or impaired. New dangers are also possible. If the law decrees that wealth shall be distributed, not as the result of brute force, but through free bargaining among producers, there is a possibility that the advantage will go, not to the man who produces the most, but to the man who is most unscrupulous in driving a hard bargain. It then becomes necessary to set up a new standard and to prohibit, not only positive fraud, but also all contracts which may be so unequal in their operation as to discourage industry and promote trickiness. Without violence, it is possible so to frame a labor contract, that the worker shall become virtually the bondsman of the employer. Thus slavery and peonage have to be prohibited as contrary to public policy. But abolish slavery, and you abolish, with the right of exploitation, the obligation of the master to care for the worker in sickness and in old 
age. Docility and trustfulness, which may have been useful characteristics of the slave, are converted in the free man into that disregard of the future which we call improvidence, and the superannuated or sick worker, who has made no savings and has no family to care for him, constitutes a new problem. Relieve the sick and the aged by means of private charity or public relief, and you run the risk of developing the institutional pauper and the tramp, those sorry by-products of civilization, who will not support themselves, but whom charity will not suffer to starve, and who may not be put to forced labor without a violation of the constitutional prohibition of involuntary servitude.

These evils, which are observed so frequently in connection with efforts to improve social institutions, lead different minds to quite opposite conclusions. Some, exaggerating the incidental evils of progress, decry all efforts at betterment, and long for the good old times when there were no reformers. Others, realizing strongly the evils which grow up without regulation, think that reform has not been carried far enough and advocate some 
extreme remedy such as socialism. In view of the difficulties which seem to attend both action and inaction, we naturally ask if there is no principle, based upon experience, which will enable us so to steer the ship of state as to avoid both the Scylla of conservatism and the Charybdis of radicalism.

In seeking such a principle, the first thing to realize is that we are living in a highly dynamic period of the world's history. We are so accustomed to change, that we sometimes do not realize all that it means, or the great contrast which exists between the rate of change of the present day and any rate which has existed in any previous period of the known history of the world. These changes are seen, not only in the endless improvements in mechanical processes with which the great inventions of the eighteenth and nineteenth centuries have made us familiar. More recently this spirit of progress has taken hold of what throughout history has been the most conservative of callings, and agriculture is now stimulated and vitalized by the application of science. New types of plants and animals are introduced in order 
to meet peculiar conditions; new methods of farming are devised by which dry lands, which have hitherto been considered infertile, are impressed into the service of an increasing population. The really significant thing with regard to these and other improvements is not that they are numerous and far-reaching, but that they are being deliberately planned. They are no longer the happy inspiration of the casual man of genius, they are often the outcome of a course of study deliberately undertaken with a definite end in view. Such establishments as the Carnegie Institution of Washington and the Sage Foundation, the agricultural experiment stations of the several States, and many departments of our universities and schools of agriculture, are not only pushing forward our knowledge of nature and her processes, but determining in advance the lines on which progress shall be made.

An interesting illustration of the tendency to anticipate discoveries is seen in the recent history of polar exploration. For centuries the difficulties of reaching the North Pole seemed almost insurmountable. One expedition after another had 
been undertaken only to add a new chapter to the history of failures. When, during the summer of 1909 , it was announced that two explorers had independently succeeded in accomplishing this feat, it was also disclosed that each had contracted in advance with certain newspapers for the exclusive right to publish an account of the discovery, which, at the time of making the contract, was still problematical. Two things are significant in this episode: the first is the eagerness with which discovery is pursued; the second, the readiness to use a still unmade discovery as the basis of a property right. And if, as has since been proved, one of these expeditions was partly fictitious, this only makes the illustration more striking, as showing the impalpable foundation upon which a property right may be built up. When the art of aërial navigation was still in its infancy, an insurance company advertised itself as prepared to underwrite aërial risks. Every one of the fifty or sixty thousand patents applied for in our country in a single year represents a desire on the part of someone to effect a change in methods of production and to use it as the basis of some property 
THE PATHOLOGY OF PROGRESS

right. It also represents the possibility of some dislocation of our industrial system, or some new menace to certain interests. 


\section{CHAP'TER V}

Economic Progress and Labor Legislation

Professor J. B. Clark, in his suggestive study of Economic Theory as Applied to Modern Problems, enumerates five elements as characteristic of a dynamic society: (1) An increase in population. (2) An increase in capital. (3) Changes in the methods of production. (4) Changes in the methods of organization. (5) Changes in consumers' wants. ${ }^{1}$

Each of these five features of economic progress involves some new problems affecting labor. Many of these, fortunately, solve themselves; many others do not, and the experience of a century has proved that in, at least, many cases some form of legislation is necessary in order to prevent the incidental evils of progress from being perpetuated and aggravated. Let us take them up seriatim.

1 John Bates Clark: Essentials of Economic Theory, 1907, pp. 203-206. 
1. The increase in population often involves a crowding in industrial centers with an increase in disease, which must be dealt with by tenement-house laws and sanitary measures. The increase of population combined with modern methods of transportation leads to the amazing migration of modern times, which, in turn, creates new difficulties. To prevent the spread of contagious diseases, to prevent the abuse of the newcomers, some restrictions have to be placed by law, not to stop, but to control, this flood of immigration.

2. An increase in capital tends to make large aggregations of wealth, which by their very size weaken the personal element involved in the relation of employer and employed. The simple, almost patriarchal, expression "master and servant," which served as the rubric of the law on these subjects in the time of Blackstone and, indeed, was not superseded in England as a legal term until 1875, is no longer applicable to modern industry, nor are old methods of bargaining satisfactory. New machinery must be devised to facilitate collective bargaining and to mitigate the effects of collective disagreement. 
3. Changes in the methods of production, involving, as they do, more powerful and more complicated machines, bring many evils. In the early days of the factory system, the displacement of skilled labor by unskilled was the most obvious injury felt by the workers. At the present time we are more concerned, because better acquainted, with the remoter and indirect effects of the age of machinery. We see new causes of accident, new kinds of industrial diseases, combined with a greater difficulty of securing the individual worker against the effects of accident and disease. Long experience has shown that these particular difficulties do not correct themselves, and one of the greatest problems in labor legislation at the present time is, on the one hand, to diminish accidents and disease, and on the other, to provide some form of compensation or some form of insurance for those who are their victims. Still more important, if possible, is the effect of machinery upon the children and therefore upon the workers of the future, and this, being comparatively remote and not realized for one or two generations, is the most difficult problem for the individ- 
ual to solve. Government intervention seems the only agency sufficiently powerful and sufficiently general to save a country from the deterioration of its human capital.

4. Changes in organization tend on the whole to give a new advantage to capital. It is now possible for a single company or combination of companies to be spread out over many states or many continents. This, while it makes for efficiency, also creates a power which may be abused and results in a demand for laws putting upon capital new responsibilities in the interests of its employees. It, above all, points to the necessity of interstate and international labor legislation. With the aid of the International Association for Labor Legislation, a number of international treaties of great importance have been made, one of the more recent of which is a treaty between France and Great Britain, giving the workers of those countries reciprocal advantages in obtaining compensation for accidents.

5. Changes in consumers' wants create an artificial instability of business, which shows itself in alternating periods of 
activity and stagnation. The one tends to produce overexertion, the other, unemployment, and each demands legislation.

It will be noticed that in each of these five cases the main purpose of the legislation in question is to prevent some injury to the human beings for whose sake economic progress exists, and on whose efficiency its continuance depends. We should, therefore, add to the five elements of a dynamic society which have been enumerated, a sixth, which has been comparatively neglected in the past, but which may prove in the future to be the most important of all. I refer to an improvement in the quality of the population itself. This is not altogether a dream. The average duration of the human life has within a century been decidedly lengthened in many of the leading countries of the world. In England and Wales, e.g., the average duration of life among males in the period 1838 to 1854 was $39 \%$ years, in 1891 to 1900 , $441 / 10$. In Sweden the average duration has increased from $395 \%$ in 1816 to 1840 , to $50 \%$ in 1891 to 1900 . Our statistics do not enable us to make general statements for the United States as a whole, but in 
several of the States the same tendency shows itself. ${ }^{2}$

Many diseases and many accidents are now recognized as clearly preventable. There is every reason to believe that by proper care human life can be lengthened, disease and accidents diminished, and the physical strength of the population improved; but, in order to bring about this most important element of progress, the state itself, which alone has an interest extending beyond that of the individual lifetime, must intervene, in order to prevent well-recognized causes of retrogression and also to promote those elements which make for improvement.

In this process, mistakes are pretty sure to be made. Eugenics has not yet reached the position of an exact science. All legislation that is passed with good intentions does not produce the desired results. The point to be emphasized is that economic progress in itself involves inevitably in each of its elements some form of labor legislation. As long as change continues, we must expect that labor legislation will

2 Irving Fisher: Report on National Vitality, 1909, pp. 18, 19. 
be necessary. If the laws of the Medes and Persians were immutable, it was because their economic life was stagnant. We should not forget, however, that the oriental politicians who are responsible for introducing this tradition into literature invoked the immutability of the law on behalf of a brand-new measure of their own devising, the purpose of which was to check reform by casting the reformer into a den of lions. For according to the prophet Daniel, "All the presidents of the kingdom, the governors, and the princes, the counsellors, and the captains, have consulted together to establish a royal statute, and to make a firm decree, that whosoever shall ask a petition of any God or man for thirty days, save of thee, $\mathrm{O}$ king, he shall be cast into the den of lions. Now, O king, establish the decree, and sign the writing, that it be not changed, according to the law of the Medes and Persians, which altereth not.' ${ }^{3}$ At the present day, there are no more ardent advocates of the immutability of the law, none who more zealously urge that things be left alone, than those the value of whose property rights 3 Book of Daniel, vi. 7, 8. 
rests upon some comparatively recent law, such as a liberal charter or a high import duty.

This conception of labor legislation, if it could be generally entertained by our legislators and the public, would lead to certain important, practical results.

1. Labor legislation would be less in quantity and better in quality. A measure adopted for what seems an emergency is almost always hastily drawn and soon requires amendment. As soon as it is recognized that a certain type of legislation results from permanent conditions, more care will be bestowed upon it, and the changes will be fewer.

2. Legislation would also on the whole be more prompt. Certain general effects of industrial progress are well known by the experience of other states. These are often not corrected until they have become so flagrant that they are taken up by philanthropists or trades unions, and corrective measures are then passed under pressure without due study. Legislation is often so afraid of crossing its bridges before it comes to them, that it does not keep them in decent repair. 
3. Laws would be more uniform, if labor legislation were recognized as resulting from certain general economic conditions which are universal, or nearly so. More care would be taken to secure harmonious action between different countries and different States in the same federation.

4. Labor laws would be less frequently the expression of class feeling. Many bills which excite prejudice on this ground would be recognized as being really in the general interest. The courts, too, might perhaps find it easier to distinguish between enactments which are really class legislation and as such condemned by constitutional principles, and those laws which, while applying to certain definite groups, are in reality passed for the benefit of all.

5. The recognition of labor legislation as a permanent feature of our statutes would make it more consistent, because the very thought of adapting it to changes in economic conditions would force us to think more of those economic ideals which underlie subconsciously most social legisla- 
tion, but are not always recognized or steadily followed.

Each great period of the world's history has had some such economic ideal, which, whether or not formulated in words, has become a part of the mores of the time and country and has guided the law in its main features. Under the feudal system, society was divided into horizontal strata, based mainly on their relation to land, and involving specific duties as well as rights. The guild system dovetailed quite properly with this system, although not strictly a part of it, since under it the mechanics of the cities were classified and their places definitely determined, the crafts themselves being more or less hereditary. Whatever the merits or demerits of this system, it was one of order rather than one of freedom, one of conservatism rather than of progress.

The economic ideal of the United States is very different from this. It may not be easy to define it in a few words, but its most concise expression is perhaps found in that part of the preamble of the Federal Constitution which states, after enumerating certain political purposes, that its 
object is "to promote the general welfare and secure the blessings of liberty to ourselves and our posterity." Our ideal is clearly not a caste system, nor even a hierarchy of functions such as existed under the feudal system. It is a system of freedom which implies equality of opportunity for all. This does not mean anarchy, for it is a liberty which brings blessings. It is not the paper liberty of a phrase. It is, moreover, a liberty of the race, not of the individual. All this implies, therefore, a liberty so regulated as to prevent one individual or one group from abusing their liberty to the harm of others.

This policy, though unfortunately not always realized, is seen in many typical pieces of legislation, both Federal and State. The public land policy of the United States is based upon the idea of putting the land into the hands of small farmers, and therefore preventing its monopolization by a few. The homestead exemption laws of our States interfere with freedom of contract in the interest of the family. The Federal government introduced within the first few years of its existence a system of caring for seamen 
of the merchant marine in case of sickness by means of what would now be called compulsory sick insurance. ${ }^{4}$ This remarkable piece of labor legislation, enacted in 1798, anticipated by nearly nimety years the introduction of general compulsory sick insurance by Germany, showing that, even in those early days of weakness and decentralization, the United States was ready to practice social politics, when the practicability and the necessity of it were apparent. If a few year's earlier Alexander Hamilton adrocated a protective tariff, partly on the ground that it would introduce the factory system and thus secure the employment of children "of a tender age," this was not because of any desire to break down the health of the population, but simply because the evils of the factory system were not appreciated, as were the dangers of the sailor's life.

We are fortunate in this country in having an ideal clearly expressed and pretty

4 For a full history of the Marine Hospital Service the writer is indebted to a still unpublished monograph on the subject, written by Dr. A. M. Edwards for the Carnegie Institution of Washington.

5 Report on Manufactures, 1791, p. 87 of reprint of 1837. 
generally accepted, and it is this ideal which must give consistency to labor legislation. But it is a consistency of purpose, not of words, that we must aim at. A navigator might seem vacillating to a landlubber who observed that he sailed now on the port tack and now on the starboard tack and constantly changed his helm. But through all of the apparent changes he is working steadily against the wind toward his port. Labor legislation must likewise adapt itself to the particular exigencies of the times, maintaining always as its final purpose in the United States, "to secure the blessings of liberty to ourselves and our posterity." Its very prohibitions are in the interest of a greater liberty, just as the traffic regulations of a great city put restrictions upon the individual driver for a time, in order to secure a freer circulation for the traffic as a whole.

The movement for more intelligent labor legislation is but a part of the great movement for the conservation of our natural resources. But in the construction of the irrigation works which are already reclaiming so many square miles of territory 
and turning bad lands into fertile farms, the first step is the building of a dam. There are few persons now so shortsighted as to suppose that these dams are intended to prevent the water from reaching the arid plains. Every one knows perfectly well that they are the very first condition of an adequate water supply. Likewise some restrictive legislation as applied to labor is often the condition of real economic freedom. It means that man is at last learning to apply to himself those principles of domestication, preservation, and improvement which he applied to his live stock, when he emerged from the hunting stage of existence. 


\section{CHAPTER VI}

\section{Fundamental Distinctions in Labor LegisLation}

In the scholarly presidential address, which he delivered at the first annual meeting of the American Association for Labor Legislation, Professor Ely dealt with the relations of labor legislation to economic theory. He showed that most of the early economists were on principle opposed to legislation, which seemed to them to be a futile interference with economic laws, but that their successors gradually changed their views, until at the present day there are very few who would condemn labor legislation as such. If, however, we no longer hold that all labor legislation is unscientific and futile, neither do we believe that all that goes under that title is scientific and effective. Still less do we believe that everything that is demanded in the name of labor is going to accomplish what is expected of it, even when we approve of 
its general aim. And while the doctrine of laissez faire no longer ranks as an infallible principle of statecraft, it may still serve the useful purpose of the slave who stood behind the triumphant Roman general to remind him that he was still a man. We, too, need occasionally to be reminded that, though legislation has accomplished much, it has also frequently failed; that it is apt, even when successful, to produce unexpected results; and that we cannot be too careful to study, with all of the statistical and administrative material at our disposal, the complex operation of past laws before advocating new ones. We prefer to let evils work their own cure, if they can, and we must always balance the "ills we have" against those "we know not of." We have thus reached the point at which the emphasis should be laid, not on negation, nor on agitation, but rather on discrimination.

The general term labor legislation embraces at the present day a heterogeneous mass of enactments which impinge upon the individual in very different ways, and which really fall into three quite distinct classes, if we group them with reference 
to their immediate bearing on economic processes.

In the first class, which is also the oldest, we have what is commonly termed protective labor legislation. Familiar types are laws limiting the age of employment of children, limiting the hours of employment, prohibiting certain kinds of employment to women or children, requiring the use of safety appliances in connection with machinery, limiting migration, etc. They determine the conditions under which labor must be performed, but do not directly affect the terms of exchange. They operate like dykes, which confine a river to a certain bed but do not change the flow or general course of the water.

In the second class we have legislation which aims not so much at excluding certain unfavorable conditions of labor as at the direct bestowal of pecuniary benefits. This legislation may not inappropriately be called distributive or positive legislation. Compulsory insurance laws which require the employer or the state to contribute a part of the funds would come under this head, as well as employers' liability laws, old age pension laws, laws pro- 
viding for the fixing of wages by wage boards or compulsory arbitration, etc. These laws require certain positive contributions on the part of the public, the employer, or the wage receiver, or of several of them combined. They directly affect the terms of exchange by supplementing or modifying the wage contract.

In the third class we have legislation which is designed to encourage or promote certain institutions, but which neither contains a prohibition nor an injunction, and may therefore be called permissive. Most of these laws in their application to labor involve the use of certain forms of selfhelp. In this group we should include, therefore, laws permitting and regulating labor organizations, benefit societies, cooperative associations, voluntary arbitration boards, joint boards for collective bargaining, etc.

The attitude of the law-giver towards the citizen in these three classes may be tersely expressed as follows: laws of the first class are mainly prohibitive and say "thou shalt not"; laws of the second class are mainly mandatory and say "thou 
shalt" ; laws of the third class are mainly permissive and say "thou mayest."

It would carry us too far to attempt any statistical study of the way in which the laws of these three classes have operated in practice, but their influence upon economic forces may be explained by an analogy drawn from another and less debatable department of economics. While on many topics economists are still at variance, the experience of the world in dealing with money has been so long, and it has been the subject of such careful study, that, in spite of differences of opinion regarding certain points of monetary policy, there is a pretty general agreement regarding the laws of monetary circulation. One of the most important aims of all monetary legislation is to establish a definite standard of value. For centuries the world's standards were steadily deteriorating. For many years after Sir Thomas Gresham had formulated his famous law, according to which bad money drives out good money, no means had been discovered of counteracting what seemed to be an inevitable law of monetary degeneracy. Just as soon as one metal depreciated in value, just as 
soon as the government issued coins of light weight, or dishonest people sweated or clipped the coins, the inferior coins tended to remain in circulation, while the better ones were melted down or hoarded. The competition of those who had money to sell-that is, who wished to buy goodstook the form of offering the poorest money that the other party to the bargain could be induced to accept. Gresham's law was, however, not an inevitable law of nature. Like all economic laws it expressed a tendency; therefore, it expressed what will happen under conditions favorable to that tendency. It did not say that the tendency could not be neutralized by changing the conditions. And as soon as the government decreed that coins below a certain weight and fineness should not be received as legal tender, and provided for the retirement of light coins, the profit on using cheap money disappeared. The question was no longer, How bad a coin can be palmed off for a certain kind of merchandise? but, How much merchandise shall be given for a standard coin?

Now there is a close analogy between the condition of things in the world of 
money down to the end of the eighteenth century, and in the world of labor during a good part of the nineteenth. In the wholesale and impersonal demand for labor which grew up with the factory system there was a natural tendency to employ those who would work for the longest hours and at the lowest wages. The result of employing this cheap labor was in the end to also make labor less efficient, and therefore worth less to the employer. It was practically impossible for the individual to fight against this tendency. An employer who deliberately paid higher wages in the expectation of getting more efficient labor was in the position of a person who should endeavor to raise the standard of the coinage by always paying out the best instead of the poorest coins that passed through his hands. He would have his trouble for his pains, and others would reap the benefit of his liberality. When laws were passed against child labor, limiting the hours of employment, limiting the age of employment, etc., and enforcing them by inspection, a new standard was created. The buying and selling of labor did not cease. The demand and 
supply acted as before. But the conditions under which they acted were changed. A child of ten years was no longer legal tender in the labor market. A day of thirteen hours was no longer a legal standard of time wages. The government did for labor what it had done for money, by providing that certain kinds of service should be as illegal as were certain kinds of money. The intervention of the State established a standard, changed the conditions of competition, and made it impossible for the employer to employ labor below a certain grade.

Labor laws of the second class, which I have designated as "distributive," also have their analogy in monetary legislation. Just as the monetary standard has sometimes been changed in order to benefit a certain class, especially to bring about a redistribution of wealth between debtor and creditor, so most of these laws endeavor to bring about a redistribution of wealth either between employer and employed, or between present and future income. If the government, e.g., issues paper money which is worth only 90 per cent of its face value, the debtor gains a 
hundred dollars on every transaction of a thousand dollars.

Just so a law providing for compulsory insurance at the expense of the employer virtually says: Whenever you owe $\$ 1$ in wages you are obliged to pay not merely the $\$ 1$ stipulated, but $\$ 1$ plus a certain percentage needed to pay for the cost of insurance. Now while changes in the value of money which are brought about by unforeseen variations in the value of the metal may produce beneficial effects, history has taught us the danger of changes which are made deliberately with the intention of helping one class at the expense of another, and the history of labor legislation likewise shows that such a danger is inherent in all legislation of this kind. The danger is not great enough in all cases to condemn it. But there is always a risk of demoralizing the class supposed to be benefited in any law which produces a gratuitous distribution of property, unless carefully guarded against abuse. This danger is seen in the inheritance of millions by an irresponsible heir, in the marrying of millions by a conscienceless fortune hunter, in the subsidizing of industry by a protective tariff, no 
less than in lavish poor relief and in the transfer of wealth by law to the working middle class. All such laws are exposed to a danger not found in laws of the first class, which involve primarily a restriction rather than a privilege.

Labor laws of the third class also find their analogy in monetary legislation. Laws providing for the chartering of banks are here the counterpart of laws providing for the organization of trade unions, co-operative societies, and voluntary arbitration boards. A national banking law does not necessarily create national banks. National banks exist only if there are enterprising capitalists who desire to organize themselves under the law. For the same reason a law permitting the existence of trade unions does not necessarily lead to their formation. No unions will be formed, unless there are people who can command the intelligent leadership and interest needed to organize them. The form, too, which they take will depend upon the national character, the economic and social habits, the prejudices, and even theories of those concerned. Hence we see that labor unions have taken one form in 
England, but quite different forms in Germany, in France, and in the United States.

In distinguishing these three types, I do not mean to assert that they are always kept perfectly distinct in practice. Labor legislation sometimes progresses in the accomplishment of a certain end from one type to the other. The small success of voluntary schemes for workingmen's insurance led the German government to introduce compulsory insurance, thus passing from laws of the third type to those of the second. As regards savings, this matter is still regulated by laws of the third type in general, but some economists are now advocating compulsory saving as a kind of insurance against unemployment. Likewise the limited success of voluntary arbitration boards has led in Australasia to compulsory arbitration. In still other cases two methods may be combined in a single law. Thus in the Ghent system of insurance against unemployment, there is a coercive or distributive feature in that the town pays out of the proceeds of taxation a certain sum towards the allowance of those who are out of work, but it pays 
this in most cases as a bonus, added to the allowance made by labor organizations. It thus makes use of the methods of the second class to encourage institutions of the third. 


\section{CHAPTER VII}

\section{Purposes of Labor Legislation}

We have thus far distinguished between different types of legislation with reference to the way in which it operates upon the economic processes. If we now look at the general purpose and trend of such legislation, we shall see that there are two main purposes which are not necessarily antagonistic, but which are yet distinct.

The first purpose, which applies to all of the so-called labor protective laws and many of those which fall in the other two classes, is the preservation of the race and maintenance of its quality. The principal argument for protecting children and women against excessive or unhealthy work is that the next generation is threatened. The first child labor laws of Prussia were inspired by General von Horn, who, in 1828 , called the king's attention to the difficulty of getting able-bodied recruits from the manufacturing districts of the Rhine province. This same purpose applies to many other types of legislation. One of the strongest arguments for workingmen's 
insurance is that the burden which falls upon women and children in the case of industrial accidents or disease is lightened, and that thus the succeeding generation is brought up under more wholesome conditions.

Quite a different purpose appears when legislation aims to influence the distribution of wealth between different classes, when it consciously tries to raise the level of the wage-receiving class at the expense of the employers or of the community at large. These two tendencies, which are really quite distinct, are often confused. Many people, especially those of the individualistic school, are apt to group all labor legislation together as socialistic; and in many cases the very epithet, in the mind of those who use it, is enough to condemn the movement. This, however, is a superficial view. Socialism is not the only antithesis to individualism. If the extreme individualist is one who believes in the greatest liberty of the individual, he may be restrained either in the interest of his contemporaries or in the interest of his successors. The motto of the individualist who disregards the inter- 
ests of his contemporaries is, "The public be damned" ; the motto of the individualist who disregards the interests of his successors is, "After us the deluge." Thus there are two policies opposed to individualism, one of which takes into account contemporary relations, the other of which considers the element of time. Our social world, like our physical, is a world of three dimensions, not of two. From one point of view individualism is justly contrasted with collectivism or socialism. From the other it is contrasted with a movement which is in reality not new, but which is as yet so little conscious of itself that nobody has apparently thought of giving it a name. If we may be permitted to borrow a word which was, I believe, first coined by Mr. Louis R. Ehrich, we may call it "posteritism." This movement is so important for the welfare and the permanent strength of any society, and it is capable of so many applications, that it almost implies a revolution in our social ideals. The general care for the life, intelligence, and morals of the next generation, as shown in labor laws, in the steps taken for the preservation of the national health, in the fight 
against tuberculosis, and in the creation of playgrounds for children, is but part of a greater movement which also includes measures for preserving our forests and our mineral resources, for draining our swamps, and for irrigating our deserts. Still another phase of it is seen in the study of eugenics by our sociologists. It is not difficult to interest people in the preservation of our natural resources, but those who are far-seeing recognize that the people who inhabit a country are as much an asset as is its material wealth. Indeed, one without the other would be of little use. Protective labor legislation forms, therefore, a part, but a very important part, of the general movement for posteritism.

Much of this is not new. England, the states of continental Europe, and many of our own States furnish us with an abundant experience on which to base future action. And yet the matter is attended, in the United States, with peculiar difficulties which are partly legal and institutional, partly economic.

The legal difficulties arise from the very framework of our government. We have within the limits of the United States, 
excluding Alaska and our distant dependencies, no less than fifty-one different legislative bodies which have the power to pass laws for a larger or smaller territory. Our country presents a more complex legislative problem than all the states of Europe taken together. There is, it is true, no lack of labor legislation in the United States. During the year 1907 alone, no less than 405 measures regarding labor were passed, and not all of the legislatures were working that year. ${ }^{1}$ But though many of our commonwealths are far advanced and stand on a par with the best states of Europe with regard to certain matters, we find that even adequate laws for the protection of the labor of children are still lacking in many of the States, laws for the protection of the labor of women are often subject to attack and nullification on constitutional grounds. When we look at the administration of these laws, we are obliged to confess that very frequently they are not executed by experts, but that the poison of the spoils system still neutralizes, in far too many cases, the good that laws might otherwise accomplish.

1 Mass. Labur Bull., March-April, 1908, p. 69. 
While in the world at large labor legislation has already passed beyond the national stage and has now become the subject of international treaties, we are still struggling with a lack of uniformity both in lawgiving and in law-enforcing within the limits of a single country. We are not even able to command satisfactory information with regard to industrial accidents or industrial diseases in order to guide future legislation. So simple a matter as the registration of vital statistics is still in such a state of chaos that Congress has been obliged to request the States to introduce registers and has ordered a model law drawn up for their guidance. If we look at the matter in all frankness we must acknowledge that, while our industries are noted throughout the world for the inventiveness, the mechanical skill, the business talent which they command, and while we have every reason to be proud of our educational system and of our standing in international relations, we have apparently overlooked the art of legislation. The great mass of our State legislators have had no previous training in the study of lawmaking and law-enforc- 
ing. We prevent them from becoming skilled and responsible lawmakers by rotation in office, by infrequent sessions, and by constitutional limitations. The instruction which they receive from the lobby is often effective, but one-sided, since it is more apt to show them what is for their individual interest than what is for the interest of the public, present and future. There are, fortunately, signs of improvement. Expert commissions are being used more and more. The development of such institutions as the Legislative Reference Library in Wisconsin is doing much to educate our lawgivers. But the fact still remains that, of all the industries of the United States, lawmaking is perhaps the most backward.

There are also economic conditions which have made it peculiarly difficult to secure intelligent action on this subject in our country. The exhibit of the Pittsburgh Survey $^{2}$ may serve as an instructive object

2 This exhibit was opened in 1908 to show graphically some of the results of the intensive study of the industries of Pittsburgh, which was undertaken by the Russell Sage Foundation, and the details of which were later published in a series of volumes. 
lesson. A visitor to that exhibit sees, as he enters the staircase hall of the Carnegie Institute, some beautiful frescoes representing the industries of Pittsburgh in their power and energy. As he ascends, he sees another series of frescoes representing the "ceaseless movement of the people," men, women, and children passing on to work or play. It is true, as we are informed, that these figures are not idealized, but it is also true that the artist has shown but one side of the medal. The assets are there, but where are the liabilities? Where is the depreciation account? If we pass into the room occupied by the Pittsburgh Survey, we see another frieze made up of small black figures, also passing in an endless procession around the room. Each one of these figures stands for one of the 622 deaths from typhoid fever which took place within a single year. Each one of them represents a loss of earning power to the families and a loss to the community, as well as suffering and weakness for those concerned. It is fair to say also that at least three-fourths of these were preventable, for some statistics placed upon the wall show that, after the 
introduction of a filtration plant in the water supply of Pittsburgh, the cases of typhoid fever were reduced by nearly three-fourths in the course of a year. Other figures show the deaths by accident, by tuberculosis, etc. Why is it that the community as a whole permitted this waste of human life to go on? It is not due to lack of engineering skill, for the highest ingenuity is displayed in the Pittsburgh mills. Nor is it due to lack of wealth, or business ability. It is mainly due to the fact that Pittsburgh, like the country as a whole, does not breed its own workers. A very large number of them are drawn from abroad. That supply keeps on coming in spite of typhoid fever and tuberculosis and the ten thousand annual deaths by accident on our railroads. A factory or a railroad must allow in its accounts for the deterioration of its machinery, or it will soon come to grief. But the United States is like a railroad company which can always obtain new locomotives by simply paying for the expense of running them. Such a company could well afford to disregard its scrap heap. But the human scrap heap is not so easily disposed of. The premature death 
of a worker means not simply the elimination from the industrial world of another human machine; it often means a widow and children growing up in a state of poverty and want, it means a weak instead of a strong worker twenty years from now. Whatever the industrial structure of society may be at that time, whether capitalistic or socialistic or communistic, that means an economic loss. The action taken by us of the present generation to prevent that loss depends upon whether our social consciousness is able to project itself so far into the future as to be influenced by considerations which will perhaps never affect us personally. Socialism has emphasized the injustice of many of our social institutions. Posteritism points out our short-sightedness. If our motto is, "After us the deluge," we shall certainly take no thought for the morrow. But that was not the point of view of the founders of the Republic. For they framed the Federal Constitution, not only to "establish justice," but also to "secure the blessings of liberty to ourselves and our posterity." 


\section{CHAPTER VIII}

Practical Methods in Labor Legislation

Blackstone says that three things are requisite to government; wisdom, goodness, and power, and of these three, he thinks that democracies are more likely to have goodness than either of the other qualities, while in aristocracies, more wisdom is to be found. A cynic might prefer to express the same idea negatively, and to say that democracies have even less wisdom than they have goodness, and aristocracies, even less goodness than wisdom. Blackstone certainly does not entertain a very high opinion of the British Parliament of his day. "It is perfectly amazing," he says, "that there should be no other state of life, no other occupation, art, or science, in which some method of instruction is not looked upon as requisite, except only the science of legislation, the noblest and most difficult of any." Blackstone wrote some 140 years ago, but can we truthfully say that we of the United 
States have progressed far beyond the state of things then described by him? How many of our State or even national legislators have had any special training in the art of lawmaking? Even when they are lawyers by profession, they have, at best, been trained in what the law is, not in what it ought to be, and the science of legislation is still conspicuous by its absence from the curricula of our law schools. Nor do we give our legislators as a whole the benefit of such rude apprenticeship as they may gain in our State capitols. A large fraction of those who have had such experience are annually or biennially retired to private life in order to make room for others. This is true even in the state which is known as the "state of steady habits." In the Assembly of 1909, e.g., only 28 per cent of the members of both houses had had any previous legislative experience whatever. Nearly a third of them were farmers. Now farmers are as a rule estimable men, individually, but they do not often, in the State of Connecticut, find enough leisure in the intervals of coaxing a scanty living from our stony soil to devote themselves profoundly 
to the study of jurisprudence. The judiciary committee is, it is true, always composed of lawyers; but it is rather rare in other departments of lawmaking to find such impartial specialization as was applied a few years ago to the make-up of the Committee on Public Health, when two physicians were re-enforced as experts by two undertakers and a grocer!

Thus the legislation of our States, which is prodigious in its mass, amounting easily in a single year to 16,000 enactments, is mainly the product of unskilled labor. Hence, when it is submitted to the trained minds of our courts, it is not surprising that a great deal of it is condemned. The result is that, while our business men, our scientists, our professional men, our inventors, our philanthropists, are eagerly pressing forward to conquer new fields, a large part of the labor of our trained jurists seems to be employed in putting on the brakes. 'This remark must not be taken to imply any disrespect for the mechanical virtues of the brake. We need it in all walks of life. We need it commercially and socially as well as mechanically. But if you apply the brakes to a part of the 
train only, while the locomotive is under full steam, something is sure to be dislocated.

This is precisely what happens, when new processes, new methods, new forms of organization are introduced into our economic life, and the legal machinery for handling them is blocked in its development by the tardiness or weakness or carelessness of legislation. This is what happens, when we try by all means to stimulate our industries, but fail properly to protect children and women from the effects of long hours, or, having passed a law, nullify it as contrary to the constitution. This is the case, when we increase the hazards of travel and of manufacture by inereasing the speed, or of coal mining by working lower levels, and yet fail to require adequate safety appliances, or refuse to give to the individual who may be injured as the result of these processes, any indemnity, unless he is able to prove, by an expensive lawsuit, not only that someone was to blame, but that that person was not a fellow servant of his, and that he himself was not guilty of contributory negligence. Yet the principle of averaging the property 
losses of a dangerous occupation such as navigation is as old as the Lex Rhodia de jactu. If it is in the interest of commerce to apportion among the shippers the loss which arises when a part of the cargo is jettisoned to save the ship, is it not equally in the interest of society to distribute the loss when a human being is jettisoned in the dangerous processes of modern industry?

The wastefulness and inequity of our present system is at last coming to be recognized, and yet, as soon as we speak of substituting a better one, or introducing anything like compulsory insurance or workmen's compensation, we are at once met with the bugaboo of unconstitutionality, and one of the first problems of the various commissions now studying this subject is to steer clear of this ever-present danger to legislation. This is not the place for a discussion of the principles of constitutional law. They have been from the beginning of our history the perennial subject of debate between political parties, and it is more than probable that even experts would not agree in their solution of all of the questions that may arise in 
this connection. There are, however, a few general principles of interpretation that should be emphasized. One is that a power which Congress may exercise for the benefit of property, cannot consistently be denied to it, when it attempts to exercise it for the benefit of persons. Thus, if we ask Congress to impose a prohibitory tax on poisonous matches in order to protect the health of the workers, we cannot be charged with misusing the taxing power of the government, as long as Congress can impose customs duties, in order to benefit owners of mines and manufactories, and can tax State bank notes, in order to give a bank note monopoly to the national banks. We should also not forget that all of our constitutions, both Federal and State, make provisions for their own amendment, their framers thus recognizing that a change of circumstances might require a change in the powers and duties of government. We of the present generation are not honoring the founders, but rather displaying our own narrow-mindedness, if we refuse in the name of constitutionalism to make use of the power of amendment which they deliberately conferred upon us. Let 
us not forget that the law is made for man and not man for the law.

It is true that every law which affects economic and social conditions is like a piece of social surgery. It may cut deeply into the very arteries of industry; it may sever the nerves of trade and of enterprise. The recognition of this fact is often used as an argument in favor of laissez faire. Rather than run the risk of doing harm, it is better, we are told, not to do anything at all. This maxim is a wise one in a certain stage of development. It was perhaps wise in surgery before the discovery of the circulation of the blood, and of anæsthetics. But increased knowledge has made surgery bold. It is bold because it is instructed. It is precisely because the modern surgeon not only realizes the delicacy of the human body, but also understands the working of its different parts, that he can perform with confidence operations which a few years ago would have resulted in the death of the patient.

Legislation is just beginning to pass out of the primitive stage in which surgery found itself a century ago, and it is my present purpose to try to point out the 
method by which its work may become more effective and less dangerous. While much that I say has a general bearing upon all legislation, I shall, of course, speak specifically of what seem to me some of the requisites of labor legislation.

The first thing to emphasize is that every law should be preceded by a careful investigation of the facts, economic, industrial, and medical. Put in this way, the statement may seem a truism, but it is a rule that is often disregarded. It is, moreover, a rule which it is not easy to carry out in our country. In certain lines our statistics are full and trustworthy, especially the general statistics of population, collected for the decennial census; but our vital and accident statistics are very imperfect. It is clear that a legislature must work in the dark when providing against accidents and disease, unless it knows how prevalent they are. Hence the Association for Labor Legislation is working for the reporting of industrial diseases by physicians, and for fuller records of industrial accidents. It has also appointed a committee which is urging upon Congress the importance of a national investigation of industrial dis- 
eases. In this whole matter it is clear that we must work for co-operation between the sciences, especially between medicine and hygiene, on the one hand, and economics, sociology and statisties, on the other. Medical science has made marvellous progress of late years in its own field, but it is only just beginning to realize the social side of its work. The development of a social service department in the Massachusetts General Hospital and the formation of a society for the study of medical sociology in New York, are the encouraging beginnings of what we may hope will prove a beneficent and fruitful partnership between the sciences. In this field Italy has set us a splendid example by the foundation of the Hospital for Industrial Diseases in Milan. This institution contains not only the facilities for treating such diseases, but aiso laboratories in which they can be studied, and measures devised for preventing and curing them.

Besides the vital and demographic facts already mentioned, we need also to know to what extent the purpose in view may already have been attained in whole or in part by existing agencies. We may 
well profit by the example of Switzerland, which, before undertaking to introduce sick insurance, made an investigation of the work of the benefit societies. This careful statistical study showed that these societies had increased rapidly in the course of 23 years. In 1880 they insured 7 per cent of the entire population, in 1903, 15 per cent. ${ }^{1}$ This is clearly a fact of the first importance, and it has determined the entire plan of sick insurance in Switzerland, which, instead of creating new organs, has simply utilized those already existing. We are informed that in the United States some 8,000,000 adult men and women are at the present day insured in fraternal orders in addition to $3,000,000$ insured by other forms of benefit societies, such as railroad relief funds, trade unions, etc. If we assume with Dr. Brodsky, ${ }^{2}$ that each of these persons represents three others, we have $33,000,000$ of inhabitants, or a third

1 O. H. Jenny: The Problem of Sick and Accident Insurance in Switzerland, Yale Review, November, 1910, p. 241.

2 R. J. Brodsky: Paper read at the National Fraternal Congress, National Fraternal Congress Bulletin, November, 1910, p. 2. 
of our entire population, benefited by these voluntary associations.

Almost equally important is the study of pre-existing law, and above all of the legislative experience both of our own country and of others. Much unnecessary legislation is enacted annually for lack of this care. Professor Stimison quotes, as an extreme instance of it, the act passed by the Legislature of Massachusetts, some years ago, which virtually declared that the common law was the common law! ${ }^{3}$

It should be our purpose to enact no unnecessary law. But if we find that, after full consideration, there is an evil for which the existing laws do not supply a remedy, it is still important to find out what remedies have been applied by other countries, and what light is thrown by experience upon the operation of the proposed legislation. One cannot avoid the feeling that when the British Parliament passed the present old age pension act they did not take the trouble to study the German system of old age insurance, based upon the principle of contributions

3 F. J. Stimson: Popular Law-Mraking, 1910, pp. 188 and 357 . 
by the beneficiaries. It would also seem as if they had forgotten their own unhappy experience with the lavish system of poor relief which was practiced only a century ago, and which proved to be not only costly to the taxpayer, but most demoralizing to those who were intended to be benefited by it.

It would seem superfluous to mention the importance of careful drafting, were it not so often disregarded in practice. Anybody who expresses himself as opposed to stealing is liable in these days to be charged with lack of originality, and to be reminded that he is simply plagiarizing one of the Ten Commandments. Likewise a person who maintains that a law should state the intention of the legislator, and that it should be so clear that it not only can be understood, but that it cannot be misunderstood, is liable to be reminded that very much the same thing was said by Quintilian nearly two thousand years ago. But as long as people persist in violating these fundamental rules, not merely of law but of language, so long will it be necessary to lay stress upon them. Thus, not long ago in one of the New England States, 
a legislator undertook to change the dates of the appointment to office of the members of a certain city commission. When the legislature had adjourned and the amendment was printed, it was discovered that, while the law distinctly stated that there should be three commissioners, the dates were so fixed that the law could not be complied with without the appointment of four. A western State, which has in general a well-deserved reputation for care in drafting, passed a tenement-house act some years ago, which the Supreme Court of the State declared impossible of execution. The principal reason was that it was made so general as to require in country districts certain appliances which could be found only in cities. So flagrant are the violations of this fundamental rule of writing that some public-spirited citizens have recently organized a society whose sole purpose is to attend to the careful drafting of laws.

It goes without saying that the best law is futile without some provision for its execution. Labor laws are seldom selfexecutory. Factory acts involve more or less inspection of establishments which the 
owners and managers do not always welcome. The factory inspector must possess not only honesty but also technical knowledge, firmness, and tact. Yet it is notorious that in a large number, probably the majority, of our States, these important officers are appointed, not on account of their qualifications for the duties of their office, but because they have earned the gratitude of the appointing power by political services. Such men can hardly be expected to jeopardize their reappointment by an unpopular severity in the enforcement of the law. The Association for Labor Legislation has published a special study of the administration of labor laws from which it appears that only three of all our States require a civil service examination for factory inspectors. A few require the appointment of "a suitable person" or "a competent and practical mechanic." Most of them place no limitations whatever upon the appointment. The International Association for Labor Legislation is making a similar study of the administration of labor laws throughout the world, and a comparison of the bestadministered state of Europe with our own 
is not flattering to our vanity. Prussia, e.g., goes so far as to require of its factory inspectors three years' technical study in such subjects as chemistry and mechanics and, in addition, one and one-half years' study of economics and public law. They must also pass two examinations in a German university. Such extreme requirements would be plainly impossible in our country and perhaps undesirable, but they at least show how seriously the Prussian legislators take their labor laws.

A final requirement, which I should like to emphasize, is seldom recognized, and yet it is, in my judgment, of great importance. Every labor law should provide for a record of its own operations. No hospital would be considered worthy of support, if it did not keep a careful record of cases, yet our legislators are willing to project into the economic life of society a great power, namely, the power of coercing individuals, without even taking the trouble to find out how this power is operating.

A few years ago one of our graduate students was working up a study of the factory laws of one of our States, and all of the printed statistics were in such an 
unsatisfactory shape that he was actually obliged to organize a small statistical bureau in order to make the calculations needed for a comparison of the figures from year to year.

I have intentionally omitted all reference here to one topic which may seem to many the most important of all. I refer to the methods by which, when a bill is prepared, the favorable votes of the legislators may be obtained. It is clear that laws which are stillborn are no laws at all, but the art of legislative midwifery is precisely that part of the art of legislation which has enjoyed a really professional development in our country. Legislators come and legislators go, but the lobby seems to be the one stable element in our legislative halls. The Association for Labor Legislation does not expect, nor does it desire, to add to the world's knowledge of this subject, though its members may need to be reminded, and reminded emphatically, that since this art has been developed in the service of private interests, those who aim at the public interest are under a peculiar obligation to study and apply its legitimate features. 
The International Association for Labor Legislation exemplifies in its business methods the application of these practical principles. At the meeting held in 1910 in Lugano, the delegates divided themselves at once into five commissions. Each of these commissions had a certain set of topics to discuss. The work had been prepared beforehand. One of the important subjects was that of industrial poisons, such as lead, mercury, etc. The association had secured the preparation of an elaborate list of industrial poisons, together with statements regarding the symptoms produced by them and the methods of treatment. This list, prepared by Professor Sommerfeld of Berlin, had been subjected to a careful revision by Dr. Fischer. Similar studies had been made with regard to other topics, such as the hours of work in continuous industries, etc. A study of the enforcement of labor laws in the leading countries of the world has been begun and published in part. In order to secure a much-needed uniformity, one commission worked out a definition of the term eighthour shift as applied to coal mining. The Bulletin issued periodically by the asso- 
ciation gives a survey of the labor legislation of the world.

It is by such careful preparation that the work of the International Association is made effective, and it is by the same kind of work that the American Association must justify its existence. In other words, we try to apply to legislation the same study of causes, of processes, and of effects, that lies at the basis of our modern science. We aim to utilize in our lawmaking the best results of the work done in medicine, hygiene, economics, sociology, and jurisprudence. We offer no single, simple remedy for our social ills. Social panaceas we put in the same class with the philosopher's stone and the dreams of the alchemist. Avoiding indifference on the one hand and sensationalism on the other, we aim to secure practical results by scientific methods. 


\section{CHAPTER IX}

\section{Acatallactic Factors in Distribution}

The economist who received his notions of the science thirty or forty years ago through the medium of the standard textbooks must look back with a certain regret upon a time when economic processes were so alluringly simple. There were three main factors in production, land, labor, and capital, with business direction as a possible fourth. The landlord received rent, the laborer wages, the capitalist interest, and the manager profits. The product was conceived as being distributed among these four groups according to the harmonious action of self-interest, working through the processes of bargaining. Indeed, wages were often regarded as a simple quotient, obtained by dividing the wage fund by the working population, hence, like other quotients, it could be raised only by increasing the dividend or decreasing the divisor.

The more intensive study of economic facts and economic history which has taken place in recent years has, however, shown 
us that things are not really as simple as they were assumed to be. The production and distribution of wealth are influenced by many forces which are not economic in the usual acceptance of the term. Fconomics still lacks a suitable term to express collectively those processes which are not based upon free exchange, but inasmuch as the term catallacties has been applied by Whateley to the science of exchanges in the narrower sense of the word, the term acatallactic would naturally describe those economic processes in which exchange is lacking.

Not only is there a great deal of distribution which takes place without reference to the law of supply and demand, but a careful study of economic life in different countries shows us that the three elements into which the national production is usually divided by economists have by no means a perfectly fixed connotation. Each of the terms, rent, wages, and interest, may mean different things, according to the form in which law or custom has cast them and according to the limitations under which they exist. Let us consider a few of the more important cases in which eco- 
nomic processes may be influenced or modified by other, especially legal or institutional, factors.

1. Much of the distribution of wealth does not take place under the operation of strictly economic forces at all, if we understand by them the free play of self-interest working through supply and demand. For example, the transfer of wealth from one generation to another is practically never made in this way. In rare cases it may happen that a person will buy a life annuity of an insurance company, in which case the transfer does take place through an exchange of rights. But generally it is gratuitous, determined by the will, sometimes the whim, of a testator, sometimes by the dictum of law in the case of intestacy, and always under the regulation of law, which sets limitations on the whims of testators and either prevents certain dispositions, such as entails, as a matter of public policy, or enforces certain others in the interest of heirs. Much wealth is also transferred by marriage, by gifts to children, relatives and others. All of these taken together are important causes of the unequal distribution of wealth which have 
nothing to do with the play of economic forces as ordinarily understood.

Even in business much goes by favor, sometimes degenerating into "graft." The line between the two is variable and depends upon shifting ethical and legal restrictions. The salaries paid to officers of large corporations, as disclosed in the insurance investigations of New York, are sometimes determined, not by supply and demand or the market price of their services, but by the willingmess of persons controlling a corporation to vote themselves large salaries. What a few years ago was considered a legitimate perquisite is now treated as illicit and condemned by public opinion. The ability which the managers of great enterprises have to show their friends special favors is another instance of the distribution of wealth by other than economic processes. A railroad president who should supply his friends with coal out of the coal pockets of his company would doubtless be subjected to criticism. Yet that same president will give a free pass, which means coal transformed by combustion into motion, with apparent unconsciousness that he is giving 
away the stockholders' property. Manufacturers who would scorn to ask the government to give them presents from funds raised by taxation, will besiege Congress for tariff duties which allow them to tax their fellow citizens indirectly. More and more, however, either the law or public opinion is setting limits and raising the standard.

2. Even where the law of supply and demand has sway, there are often limitations placed upon its unlimited action by ethical standards, or by law. Let us take a few random examples.

a. The rate of interest in Wall Street is practically free in spite of usury laws, yet the exaction of a high rate of interest on the security of salaries is, as shown in the investigation by the Sage Foundation of the salary loan business, considered a shady occupation.

b. In the determination of rent we find occasional instances, as seen in the establishment of the City and Suburban Homes Company, where owners of property deliberately restrict themselves to a certain income. There is, of course, a philanthropic element liere, but the point to be 
brought out is precisely that here philanthropy does enter into business.

c. The buying and selling of the product of the mind is always, and of necessity, dependent upon law. The property right in a book or an invention could not be enforced without a law determining the conditions. But many ideas, often most valuable ones, are handed down as a tradition from one generation to another, and often the ingenious inventor of a machine or process voluntarily relinquishes the right which the law would allow him, as in the case of the Babcock tester.

d. Profits are often limited by public opinion or law. This sometimes takes the indirect form of an increased capital expenditure. Let us suppose, e.g., that a certain enterprise yields a net income of $\$ 50,000$ a year and that the investment of $\$ 1,000,000$ is sufficient to do the business. In this case the dividend might be 5 per cent. It is possible, however, that the directors might vote to expend an additional $\$ 250,000$ for beauty or ornamentation, in which case the stockholders could get but 4 per cent. The railroad companies are slowly recognizing a certain moral 
obligation to build handsome railway stations in order to satisfy the public. They probably do not increase the traffic, and at best aid the finances of the company indirectly by making hostile legislation less likely. As far as it goes, this expenditure represents, therefore, a deliberate restriction of profits in the interest of the public. The difference between the railroads here and in countries like Germany or Switzerland, where they are under government control, illustrates this point. A great deal is spent in our country on luxuries, such as parlor cars, sleeping cars, etc., for which a direct charge can be made, but comparatively little on the convenience or beauty of railway stations, on which no direct toll can be levied. In Germany and Switzerland it is the other way. The trains are not, as a rule, as luxuriously equipped, but the railway stations are better planned and more ornamental. It is comparatively rare for a manufacturing concern in our country to regard the asthetic element in constructing its buildings, but even here, where a factory is the dominating industry of a small town, money is sometimes spent on architecture or grounds, and to that 
extent it may be said that profits are deliberately relinquished in the interest of the general public. A corporation desiring new stock may in many States issue it at par to its stockholders, though the market price may be 150 or 200. In Massachusetts the law forces public service corporations to issue the stock at a price determined by a State commission. But occasionally in other States, corporations, when increasing their stock, offer it at a price above par without compulsion of law. These illustrations show that, whether under pressure of law, or of public opinion, or from farsightedness, public service corporations are feeling a certain obligation to restrict their profits, which doubtless means a tacit recognition that some of the income is due to the environment and should, therefore, be shared with the general public.

e. In the determination of the price paid for services there is a great deal of confusion. Supply and demand hold sway, doubtless, with regard to the great mass of services which are paid for under the name of wages. Yet even here there is probably a practical minimum determined by custom. Most people, e.g., would hesitate, 
even in hard times, to offer to employ people at half the customary rate of wages, though it might be for the immediate benefit of the worker to take this low rate rather than earn nothing. With regard to the more skilled services of the professions there are often curious contrasts. Most physicians, e.g., have a fixed charge per visit, whether the patient be rich or poor. In the case of surgeons, however, it is very common to fix the compensation by individual rather than by group bargaining, and literally to charge what the traffic will bear. The multimillionaire, simply by virtue of his wealth, will ask free transportation and other favors from a railroad, but on the other hand, if his appendix is out of order, he will find that it costs much more to remove a multimillionaire appendix than an ordinary one.

3. Quite apart from limitations created by law, or custom, or ethical standards, we are learning that the actual working of the machinery of production often depends upon the legal form which the contract takes. Let us consider-

a. The forms of capital contract. The capital for large enterprises is generally 
obtained at the present time through some kind of a joint stock company. But here again we have a great variety in the conditions under which the capital is supplied. The stockholders are nominally the owners and, therefore, have the control of the property. And yet even among them there are differences between the common and preferred stock, both as regards income and control. The writer happened to get some of the preferred stock of a certain corporation a few years ago, the common stock of which was worth very little. It turned out, however, that under the charter the common stock was given the right to vote after a certain number of years. It thus became possible for some clever people to buy up the common stock for a mere song and, by means of the voting power, to virtually force the real owners of the company to buy them out. This form of capital contract is calculated to encourage trickery and discourage careful business management. An illustration of the opposite is furnished by the experience of two of the smaller commonwealths of Europe. The prosperity of the Island of Guernsey is attributed to a considerable extent to a 
form of loan upon real property, known by the French term rente. ${ }^{1}$ This is virtually a mortgage which cannot be foreclosed, as long as the borrower pays his interest, so that the interest becomes a fixed charge, and the profits all go to the worker. It is said that many people, starting without property, have through this form of loan become prosperous farmers. It is interesting to note that the new Swiss Civil Code, which has recently been adopted by the Swiss Confederation, provides for a form of loan on land known as the Gült. The institution is very similar to the rente of the Island of Guernsey, and it is said that it was introduced into the Civil Code of the Confederation, because it had worked so advantageously in some of the smaller cantons.

b. When we come to the relations of labor to the employer, the variety is still greater. Even under slavery, which may be based upon contract as well as upon force, we have many modifications of, and many degrees in, unfreedom, such as serfdom, peonage, the indenture system. Even

1 II. Rider Haggard: Rural England, Vol. I, 1902, pp. 79-83. 
when slavery, pure and simple, is the rule, there may be a limitation like the coartación, which prevailed under the Spaniards in Cuba, and according to which a slave might, by paying a part of his own value to his master, legally limit his master's property right and make it more easy to secure freedom. ${ }^{2}$

The wage system itself permits of an indefinite number of variants. Some years ago David Schloss enumerated, without exhausting the subject, nine different kinds of wage contracts which were common in England. In certain occupations where gratuities are customary, the gratuities may themselves not only constitute the entire income of the employee, but be so large that he can afford to pay his employer for the privilege of working for him. This represents one extreme. A good historical example of the other extreme is the wage contract made between Laban and Jacob, when the latter agreed to work seven years for the former in order to get a wife, and then received an inferior article in payment, so that he had to work

2 Hubert H. S. Aimes: Coartación, Yale Review, February, 1909, pp. 412-431. 
seven years more to secure what he had contracted for in the beginning. Besides the indefinite number of possible wage contracts which lie between these extremes, we find that in many countries certain terms are read into the contract by law. This is especially the case in countries like Germany, which since 1884 has provided compulsory insurance for certain classes of workers. This idea has spread so far, that more than half of the population of continental Europe west of Russia is now living under laws which provide more or less in the way of compulsory insurance. The older wage contract may be considered as in a broad sense an insurance contract, in so far as the wage receiver, by drawing a stipulated income, is insured against the chances of loss in the business as a whole, and this principle is confirmed by laws which, like labor lien laws, give the wage receiver a preferred claim upon the property of the employer. Compulsory insurance against accident, sickness, and invalidity goes a step further and insures the laborer against loss of his own working power. In still other cases the law may intervene, not simply to add compulsory 
stipulations to the simple contract, but to determine the terms of that contract, or the methods of making it, with a view either to securing what is supposed to be an equitable rate of compensation or to preventing disputes. The Wages Boards and Compulsory Arbitration systems of Australia and New Zealand are instances of this. Even a purely mechanical device like the taximeter may be the means of avoiding disputes and save the wear and tear of bargaining. Whether all ox any of these devices are commendable or not, is not to be discussed here. They are mentioned merely to show the great extent to which the complete freedom of contract is hedged about by law, for the purpose of preventing certain definite evils which have shown themselves in the modern industrial world. These laws do not abrogate competition. Supply and demand are still active. Both parties are still striving to get as much as they can for what they give in return. But the laws do define the limits within which this competition is obliged to act. This function of law may be compared to the effect of the channel on the character of a river. One and the same 
force impels Niagara and Meander. But whether this force of gravity produces a sluggish stream, foaming rapids, or a sheer waterfall, depends upon the bed through which the water moves. The legal forms of the wage contract are the bed on which supply and demand act, and whether economic processes shall be quiet or turbulent, productive or inefficient, depends in part upon the legal channel to which they are forced to confine themselves.

The great variety in wage contracts already mentioned and the efforts which are made, not only by law but also by employers on their own initiative, to improve the relations of capital and labor, show that the industrial world is feeling around for a method of diminishing the evils which have shown themselves in connection with the wonderful productive efficiency of the past century. Some of these efforts have proved abortive, as is seen so often in the history of productive co-operation and profit sharing. Others contain an element of paternalism, which often introduces new difficulties while removing some of the old ones. Among these various experiments there is one which is so remarkable, not 
only for the careful manner in which all of its provisions have been elaborated, but still more for the motive and theory which have inspired the inventor, that it deserves a brief description. This will be presented in the following chapter, not with the idea that a complete solution has been found here for the labor problem. Too short a time has elapsed since its introduction to warrant any final conclusion, favorable or unfavorable, regarding its merits, and the writer is of the opinion that many of its features would be impossible in other industries or under other circumstances. It is believed, however, that an explanation of its character cannot fail to be instructive to all who are seeking tentatively to improve conditions, and it is particularly valuable as an illustration of the ways in which the relations, both of labor and of capital, to an industrial organization may be modified for social purposes. 


\section{CHAPTER X}

\section{A Socialized Business Enterprise ${ }^{1}$}

In the year 1846, a young mechanic named Carl Zeiss established a workshop for making scientific instruments in Jena. The founder of this simple business was born in 1816, in Weimar, and was the son of a toy merchant, who incidentally had been the instructor of the Grand Duke, Karl Friedrich, in the art of lathe turning. The son had studied in the gymnasium and had then learned mechanics in several workshops before he established himself in Jena. The business, although very small, was a success from the start. Sim-

1 Acknowledgment for the facts stated in this article regarding the Zeiss establishment is hereby made to Professors Felix Auerbach and Julius Pierstorff and to Dr. Fr. Schomerus, who very courteously gave personal explanations to the writer in Jena; he is also indebted to the following works: Ernst Abbe: Gesammelte Abhandlungen, dritter Band; Felix Auerbach: Das Zeiss-werk und die Carl-Zeiss-Stiftung in Jena; Fr. Schomerus: Das Arbeitsrerhältniss bei der Firma Carl Zeiss, Jena, 3te Auflage, 1909 ; Siegfried Czapski: Ernst Abbe als Arbeitgeber; A. Winko.lmann: Ernst Abbe. 
ple microscopes were the chief output, and some two hundred instruments of a rather primitive type were sold. From simple microscopes he proceeded to the manufacture of compound instruments, always aiming at an improvement, but feeling the difficulty of obtaining better results by mere empiricism. It was fortunate that Zeiss was able to secure the services at this critical time of Ernst Abbe. Like his partner, he also was a native of the little Grand Duchy of Sachsen Weimar Eisenach. He was born in Eisenach in 1840 . He was the son of a spinner, but had the advantage of a scientific education, studied in Jena and Göttingen, where he took his doctor's degree, and finally settled in Jena in 1863 as Privat Dozent. He entered into partnership with Zeiss in 1866, was made extraordinary professor in 1870 , but declined a full professorship in 1874 in order to devote his attention to the optical works. Abbe supplied the scientific mind which was needed to supplement the business talent of Zeiss.

It was found, however, that one great difficulty in obtaining results lay in the imperfect and uncertain character of the 
glass. There were practically at that time only two kinds of glass known, crown glass and flint glass, and it was difficult to get the glassmakers to experiment in the formation of other types. This important element was added by Dr. Otto Schott. Stimulated by an essay of Abbe, Schott began in 1881 extended experiments in new combinations and moved in 1882 to Jena, in order to prosecute these on a larger scale. The glassworks established there in 1884 were, and have continued to be, a distinct establishment under a separate name, i.e., Schott und Genossen, but Zeiss had an interest in the business. The first catalog was issued in 1886, and it contained such a large number of novelties that a new era in instrument building dates from that year.

From this time on the optical works made rapid progress. One department after another was added, until the establishment contained six different sections: (1) the microscopic; (2) the division for projection and microphotography; (3) the photographic division; (4) the astronomical division; (5) the terrestrial telescope division; (6) the division for mensuration. 
An account of the various improvements and inventions which have originated in these works falls within the province of the physicist and need not detain the economist. The most popular, perhaps, is the trieder binocular, the principle of which was applied as early as the seventies by Abbe. Others are the relief binocular telescope, of which the two arms are hinged, so that according to will one can either get an exaggerated stereoscopic effect, or, by placing the two arms together, look over a wall or around a corner; an instrument for measuring distances; huge astronomical telescopes; and an epidiascope, which will project upon a screen either lantern slides by transmitted light, or opaque pictures by reflected light. The works have steadily increased in size and the employees in numbers. Beginning with one assistant, Zeiss had gradually enlarged his force, until he had between three and four hundred in 1888. By 1900 the number was over a thousand, and in the spring of 1908 it had tonched two thousand, exclusive of some eight hundred employed in the glassworks. The simple buildings have grown into a great mass, filling a 
large city square and spreading out beyond it. These few technical and mechanical facts are given in order that the reader may understand the kind of an establishment that we are dealing with.

Carl Zeiss died in 1888, leaving his name to the works, and recognized as an important contributor to optical science by the University of Jena, which gave him an honorary doctor's degree in 1881. He left a son, who was for a short time only connected with the business. His withdrawal in 1889 left Abbe as the virtual head of the business, though supported ably by such men as Siegfried Czapski, Max Fischer, and Rudolf Straubel. He retained this position, however, for only about three years, for in 1891 he founded the ZeissStiftung. As already mentioned, Abbe was the son of a spinner. He had, therefore, experienced the hardships of long hours and small pay. He had now become the proprietor and manager of a large industrial establishment, but had not forgotten the surroundings of his youth and was able to realize the human side, as well as the financial and scientific sides, of great enterprises. Though absorbed in his work, he 
had found time to give a good deal of thought to public and social matters. His essays, which were published after his death, fill five good-sized volumes. Among these are observations on various subjects, political and social, and from these writings we are able to learn something of the motives and reasons that guided him in creating the Zeiss-Stiftung. To adequately describe this foundation is, however, not easy. Its statutes alone fill sixtyeight pages of the works of Abbe, and his commentary upon them fifty-eight more. It will, therefore, be seen that it is decidedly complicated, much more so than the constitution of the United States. All of the details cannot be given, and only the leading features will be set forth. The provisions fall into two general groups, regulating (1) the ownership; (2) the relations with the employees.

The conditions of ownership are so peculiar as to be almost unique. The foundation is neither a partnership nor a joint stock company, nor is it a charitable institution. It is a business corporation, owning and controlling the optical works, but it operates under the final control of 
the state. This follows to a certain extent from the statement of the purposes, which are enumerated as follows:

A. Appertaining to the works.

1. The cultivation of the branches of instrument making which are established in Jena.

2 . The permanent provision for the economic security of these enterprises and for the maintenance of the labor organization which is connected with them.

3. The accomplishment of greater social duties than a personal owner could permanently guarantee for the purpose of bettering the personal and economic position of all of those who co-operate in the works.

B. Outside of the works.

1. The promotion of the general interests of the mechanical arts involved.

2. Participation in institutions and measures which are in the general interest of the laboring population of Jena and the neighborhood.

3 . The promotion of scientific and mechanical studies.

It is clear that these purposes might be carried out by an individual or a joint stock company, but it would be difficult to insure their observation under the conditions involved in the unrestricted control of private owners. The foundation 
as a legal personality is represented by what is called the Stiftungs-Verwaltung, or governing board. For the management of the business there are in addition the Vorstände, or managing boards, one for each of the works that may exist at any time, and a commissioner, who represents the governing board in the meetings of the managing boards. The rights and duties of the government of the foundation are entrusted to that department of the grand ducal government which has charge of the University of Jena, and the permanent commissioner must be a ligh officer assigned by the minister to this duty. The enterprise is thus under the ultimate control of the government, subject always to the terms of the trust. Each managing board of a business enterprise must consist of a group, which, however, cannot contain more than four members. In the case of the optical works, at least one member of this board must be connected with the management of the glassworks. The members are appointed by the government, after due consideration of the report of the commissioner and of the other members of the board, and no one can be appointed 
against the unanimous vote of these members. Only those persons can be appointed who are experts, either in science or in business, and at least one member must be an expert scientist in the subjects concerned in the business. This board practically manages the business interests, and when the Zeiss-Stiftung was fully developed and its statutes adopted, which was not until 1896, Abbe simply became one of the three members of the board of the Zeiss-Werk. The statutes provided that they should not be revised for ten years. At the end of that time, in 1906, some minor changes were made, and the description given here will apply to the statutes in their present form. Elaborate provisions are made, under which further amendments may be introduced, but they are not encouraged.

In describing the relations of the employees to the establishment, it is important to emphasize at the outset that Abbe intended to maintain in the fullest sense of the word the freedom of the employees and, therefore, to avoid anything savoring of paternalism, either in the good or bad sense of the term. That is to say, he did 
not wish to have the business treat its employees like a fairy godmother, nor, on the other hand, to take advantage of their dependence upon it in order to influence either their political or their social ideas. His aim was to make their relations business relations, nothing more. Business, however, does not necessarily mean the crudest form of business. Labor contracts may, as already stated, take any form from the simplest to the most complex, without departing from the business basis. It goes without saying, therefore, that all of the insurance features required by the German insurance law are included in the labor contract, and it is not surprising to find that some of these features were voluntarily anticipated in the works before the $Z$ eissStiftung was created, and before the insurance laws were passed, while others have been elaborated beyond the requirements of the law. Thus compulsory sick insurance was introduced as early as 1875 , and after the passing of the imperial law, the fund was converted to conform to that law. In 1888, on the day of the death of Zeiss, a system of old age pensions was introduced. In 1892, a further step was taken in guar- 
anteeing a minimum weekly compensation, provision for overtime, etc., and in the same year the semi-annual medical examination of juvenile workers and apprentices was introduced as a prophylactic measure against sickness. In 1893 a special savings bank for the establishment was introduced. Since the full establishment of the statutes of the Stiftung, the labor contract includes, besides the ordinary insurance features already noted, many other provisions. The very first article of the statutes relating to employees says that they must be appointed without reference to race, confession, or political party. They must also be permitted to exercise their general personal and political rights. To take up some more of the details, the regular workingday is limited to nine hours; no one is obliged to work overtime or on holidays, excepting in the case of interruptions of the works, and contracts for overtime cannot be made for more than four weeks. All workers over eighteen years of age are entitled to a holiday of twelve workingdays, and if any are appointed to honorary offices in the service of the empire, the state, or the town, the necessary leave of 
absence must be given for this purpose. Provision is also made for committees to represent the workers.

All must be appointed for a time wage, which is fixed in advance, per week or per month, and is to be paid for the holidays which fall on week days, but otherwise they are to be paid only according to the time which is spent. This pay cannot be lowered in the case of a temporary or permanent slortening of the working-day, unless the man in question is unable to continue his former activity, or, for reasons which lie in himself, passes over to another position. In the case of piece work, the fixed time wage counts as a minimum income, and pay is continued during the regular yearly vacation.

Important incidents of the labor contract are, of course, the insurance features. The sick fund cannot give the members less than full allowance for a half year (since extended to a year), three-fourths of the average wages as a sick allowance, insurance of the nearest family members, free choice of the physicians among the certified physicians of the dwelling place, and obligatory contribution on the part of the 
management equal to the contributions of the insured. Employees who have entered the service before their fortieth year and have worked for five years have a legal claim for a pension, if they become unable to work or otherwise to continue their activity, except for gross faults on their part, while those dependent upon them also receive an allowance. In general, the pension amounts to 50 per cent of the nominal wage for those who have worked between five and fifteen years, and it increases by 1 per cent up to the fortieth year. The total may thus become 75 per cent of the wage. Nothing is said about insurance against accidents, as this is regulated under the general laws and is a charge upon the business. One of the most peculiar and significant features of the labor contract is the provision for an indemnification upon dissolution of the relation. Two weeks' notice must be given on either side, for ordinary workers, and six weeks' for those in the business office. In addition to this, those who have been in the service for three years, after the completion of their eighteenth year, have a claim for indemnity, if they are dismissed with- 
out being incompetent to continue their work or are guilty of some fault which has led to their dismissal. This indemnity takes the form of the continuation of their previous wages for the six months following their dismissal, and for those who have a claim to a pension, the indemnity cannot be less than the amount of their invalidity pension for a period equal to a quarter of the time of service on which it would be reckoned. Thus the longer a person has been in the service, the larger his indemnity. His dismissal for some serious fault, such as drunkenness, dishonesty, etc., causes the forfeiture of this right. The reason for this peculiar provision is not so much to give the men a present as to bring a pressure to bear upon the manager not to cut down the number of hands unnecessarily in a period of business depression, which in turn, of course, implies not increasing them unduly in case the business becomes suddenly active. The aim is to maintain a certain steadiness in the number of employees and thus avoid violent fluctuations.

Not less important than the provisions regarding the employees are those which 
relate to the profits. Special clauses define the statistical methods which are to be applied. These may be roughly condensed as follows. The yearly expenditure is the sum of all expenses and obligations which are due within the fiscal year, including the payments for pensions, etc., which are to be treated as part of the cost of production. The business gain or deficit is the difference between the expenditure as just defined and the total income; the net profit of each establishment is obtained by taking into account a proper amount for depreciation and interest on the capital, which shall include, besides the regular rate of interest on mortgages, a premium for risk, corresponding to the average loss of capital in similar industries. This, however, is not the amount available for dividends. In order to secure the permanency of the works, a certain sum is set aside for a reserve fund, which includes among other things a sum necessary to secure the various demands for pensions, indemnities, etc., a sum for extending the business, and a sum to make good a possible loss. When it has reached an amount sufficient to meet these requirements, a constantly 
diminishing sum is to be added to it. After all of these demands are met, the Stiftung is, according to circumstances, to set aside one-half or three-quarters of what remains for the purposes expressed in section $B$, namely, the general interests of the industry or of science. The final disposition of the reserve fund rests with the Stiftungs-Verwaltung, or administration. Special provision is, however, made for sharing the profits with the employees. The percentage which is thus to be added to wages and salaries from the profits is to be determined from year to year in such a way that, taking account of the fluctuations in the activity of business, a proper relation shall exist between the share of the employees and the share of the foundation, according to the specified provision made for this purpose. These are defined in a general way by the statement, that the aim is not so much to increase the net profits as the total output, and that the Stiftung shall retain that part of the profits which has been earned, not by the laborers as individuals, but rather by the organization as a whole and as a going concern. 
A word should be said regarding this socalled profit sharing. Abbe himself once delivered an address on the subject, in which he took up the various arguments commonly urged in favor of profit sharing and rejected them all. One point that he especially emphasized was that the system was liable to be illusory, because there was always great danger that the nominal wages paid would be reduced by the amount paid as a share in the profits, so that the total wages would be no more than before. He put no faith in the power of profit-sharing devices to conciliate the differences between the employer and employed. ${ }^{2} \quad$ Nevertheless, he introduced a system of profit sharing in his foundation on other grounds. The share in the profits was not intended to give the worker in good years more than he would ordinarily receive. Nevertheless, it was important, because it made it possible to establish nominal wages which in bad years would secure the laborer against having his earnings pushed below a certain level. He illustrates his point by a simile. In the industrial organization of the optical

2 Abhandlungen, Vol. III, p. 109. 
works, he states, there are two beams upon which the important interests of the working forces are supported. One is a strict wage system, by which the manager is pledged to certain minimum rates even in bad years. The other is the financial strength of the enterprise, on which the execution of this wage system depends. In order that these two beams may be held together they are supported by a special bolt, that is, the profit which in good years makes the income of the workers depend upon the fluctuations of business. On this bolt there is a pretty rosette; namely, the pleasure which the individual gets from sharing in the profits. The significant thing, however, is not the rosette but the bolt. In point of fact, the enterprise has yielded profits enough to be divided every year but one, but the amount has varied considerably, ranging, except in the year 1902-03 when nothing was divided, from 5 per cent to 10 per cent. ${ }^{3}$

The nominal working-day, as already stated, was limited by the statutes to nine hours. In point of fact, they have had an

3 Schomerus: Arbeitsverhältniss, p. 10. 
eight-hour working-day since 1900, and the manner in which this change was brought about is so characteristic that a word or two should be said about it. At the beginning of 1900 the question was put to the employees: "Who is willing to try to produce as much in eight hours as hitherto in nine hours?" About six-sevenths of the employees voted for the experiment, and the eight-hour day was introduced provisionally for a year. The result was very satisfactory. It could not be measured exactly, excepting in the case of the piece workers, but it turned out that here the output was not only not less, but that it had increased about 4 per cent. When the matter was looked into more carefully, and the workmen questioned, they said that in the beginning they worked very hard in order to keep up their production and their pay, but that they found this too exacting; then they dropped into the old pace and wanted a return to the nine-hour day. The figures showed, however, that they had not gone back to the old pace. They had given up the killing pace, but had returned to one which was still higher than the old one and yiclded a slightly larger output. 
Abbe explained the matter in a very simple way. He established an equation of human exertion, according to which the daily expenditure of energy must be equal to the daily replacement; this expenditure depends upon three elements : (1) the production; (2) the speed; (3) the fatigue during the intervals of labor, the seconds or minutes lost in driblets, while standing or waiting in the noise and the bad air of the factory. These driblets are worth nothing for relaxation, but if they can be cut short and the time lumped, they are valuable. The point is to gradually shorten the time of labor, until the gains coming from a longer period of relaxation and a smaller waste of time are still greater than the loss due to increased speed. The limit represents the optimum. This will, of course, differ according to the occupations and the intelligence of the people. The case could not be proved so exactly for the time workers, but it was thought that liere, too, there was no loss of output. The consequence is that since April, 1901, the eight-hour day has been the rule. The hours vary according to the season. In summer they are from 7 to 11.30 and 1.30 
to 5 ; in winter, from 7.30 to 12 and 2 to 5.30. Pauses for luncheon, morning and afternoon, are, however, now abolished and the prohibition of drinking during the working hours has, doubtless, something to do with the favorable results of the shorter day.

Some incidental features should still be mentioned. A good deal has been done for the general education and benefit of the people, especially in the maintenance of the Volkshaus, with a fine library, readingroom, etc. Baths, too, have been introduced. The factory has even gone into the business of manufacturing temperance drinks to sell to the employees, and of selling milk to them on a large scale. Money is loaned, to help people build houses, at a moderate rate of interest. But there are no company houses. There are schools for instruction in trades, etc. The question of patents is distinctly dealt with in the statutes, and it is provided that such inventions, improvements, etc., as are useful for the promotion of science, shall not be protected by patents or similar measures. In point of fact, however, the concern has been obliged to take out patents in self- 
protection, and they are regarded as a necessary evil. ${ }^{*}$

Not only the workmen in the ordinary sense of the word, but also the officials of the company have to be provided for. It goes without saying that the higher officials receive higher compensation, on account of the greater responsibility put upon them, but, in order that they may not be tempted to unduly raise their own salaries, it is provided that the highest compensation shall not be greater than ten times the average yearly income of all persons over twenty-four years of age who have been in the works at least three years, according to the average of the last three business years. Moreover, the members of the boards of managers do not share in the profits.

In the beginning mention was made of the inclusion of certain public purposes in the Zeiss Foundation. These have been realized mainly by gifts to the miversity. Indeed, the effect of the works has been, not only to add very considerably to the population and prosperity of the town, but also to rejuvenate the university to an 4 Auerbach, l. c., p. 146. 
amazing degree. Thirty years ago the University of Jena, although old, was small and badly equipped. The profits of the Zeiss works have not only been used to add certain regular funds, but also to make extraordinary improvements. Among these are new buildings for the physical, hygienic, and mineralogical institutions, the creation of an institute for scientific microscopy, an extension of the chemical institute, and the addition of a seismographic institute to the astronomical observatory. Otto Schott has also given large sums, especially for technical physics and technical chemistry, out of his private means. Finally, the entire scale of professorial salaries has been reformed and raised. ${ }^{5}$

One naturally asks, What are the results of this elaborate arrangement? It is clear that the time is not ripe for any final judgment. Only about fifteen years have elapsed since the foundation came into complete working order. It has not been subject to the test of hard times, or of a change in the spirit of its management. The personal respect for the founders doubtless still counts as a factor in pre-

5 Auerbach, l. c., pp. 148, 155. 
venting friction. Moreover, it must be remembered that this particular form of manufacturing is exceptional. It deals with mechanics of a high grade, intelligent and highly paid, therefore relatively stable. It turns out a product which contains high value in small bulk and is, therefore, relatively independent of questions of transportation and local conditions. It would be altogether rash to assume that its success in Jena would necessarily make it a model for manufacturing establishments in general. The enterprise as a whole is, of course, eminently successful. Its product is of the highest grade, the men are well paid, the average wage being about 1,900 marks a year, ${ }^{8}$ and the relations are on the whole peaceful. They have never had a strike, though such a disturbance was once threatened. Dr. Schomerus is especially appointed to look after the relations with the men, and his tact and skill are doubtless of great importance. He stated that the fact that the management were so easily approachable led to a considerable number of small explosions which prevented discontent from gathering to create ${ }^{6}$ Auerbach, 1. c., p. 123. 
a large one. Many details in the scheme are even now criticised. Some authorities think that the limitation of the salaries of the head men keeps them altogether too low. It is clear that if the average wages are 1,900 marks, the maximum for the managers must be about 19,000 marks, or less than $\$ 5,000$. If one may judge from the results, the system is hard on the brain workers. Both Abbe and his successor, Czapski, died comparatively young, the former at sixty-five, the latter at forty-six, and apparently overwork was not without its influence in shortening their lives. Though the conditions of employment would seem to be ideal, the hours being short, the wages high, the buildings clean and well equipped, the insurance features liberal, there are yet a good many socialists among the workers. We are told that out of about two thousand employees, some two hundred would be classed as office men and of the remaining eighteen hundred about eight hundred belong to the socialist unions, or Gewerkschaften, about one hundred and fifty to the liberal Gewerkvereine. This is, of course, not necessarily a sign of discontent with the conditions of em- 
ployment. When a business is increasing so rapidly, it must draw a considerable part of its workers from other places, and they naturally do not give up the political affiliations which they have perhaps cherished for years. On the other hand, the fact that they belong to a party which is in its faith, if not in its works, revolutionary, also indicates that they do not believe that they have found an economic paradise, even in Jena. It would not be strange, perhaps, if all of the two thousand employees did not fully share the ideal aims of the founder, even though they are perfectly willing to share in the profits which his genius has made possible, and it is said that they sometimes begrudge the large sums given to the university.

The interest and significance of the Zeiss-Stiftung to the writer lie more in the motives and ideas which it embodies than in its details. Many of the results accomplished by the Zeiss-Stiftung are accomplished by great enterprises in other parts of the world under a different form. When, e.g., Mr. Carnegie gives ten millions of steel bonds to found an institution for scientific research, he is putting the United 
States Steel Corporation under the obligation of contributing a certain part of its earnings toward this purpose, very much as the managers of the Zeiss-Stiftung set apart some of the earnings of the works in order to promote scientific study in the University of Jena. Likewise when the steel corporation and other companies set aside some of their stock to be acquired by employees, they give these holders, not only a share in the profits of the business, but also an interest in preserving the permanent strength of the whole enterprise, as distinguished from the temporary advantage of one class of workers. The steel corporation, however, was founded to make money for its stockholders and bondholders. It is merely through an act of generosity on the part of individual owners of securities that it may be made to contribute toward scientific research or other public objects, whereas the social relations of capital are recognized in the very business constitution of the Zeiss-Stiftung. 


\section{CHAPTER XI}

\section{Social Myopia}

In the parable of the Good Samaritan we are told of a man traveling from Jerusalem to Jericho, who "fell among thieves, which stripped him of his raiment, and wounded him, and departed, leaving him half dead." The Samaritan saw his plight; took him to an inn; spent the night with him; and as he paid his bill on the morrow said to the innkeeper, "whatsoever thou spendest more, when I come again, I will repay thee." The Good Samaritan showed all of the traits which we still consider most valuable in the charitable at the present day. He had a lively sympathy, which caused him to stop and inquire into the condition of the wounded man; he had the spirit of altruism, which impelled him to give aid; he had practical sense, which enabled him to do it in the most effective manner; and he had the imagination to think of the future and

1 Luke x. 30. 
provide for its needs. All of these qualities we recognize as good, but do we always apply them? Above all, do we sufficiently cultivate the social imagination?

In reading the parable, one is almost tempted to imagine a sequel to the story, in order to more thoroughly adapt it to modern conditions. Let us suppose, for example, that, when the kind deed of the Samaritan became known in Jerusalem, it stimulated others to follow his example. A number of well-meaning people united themselves into a society to establish a hospital on the way from Jerusalem to Jericho, and equip it with doctors and nurses, in order to give treatment to all who might fall into the hands of thieves by the way. The hospital did a large business, and the demands upon it increased so rapidly that one generous individual decided to endow it with a fund, out of the income of which those who lost their money by robbery might be reimbursed. After many years of operation, during which the demands made upon it fully justified its existence in the minds of the founders, the Samaritan happened to come back to Jerusalem and attended the annual meet- 
ing of the society. Whereupon he arose and addressed the members somewhat as follows :

"I have studied the work of this society for many year's, and it seems to me that a large part of the money which we are spending goes into the pockets of the thieves. If they see a defenseless traveler going to Jericho, they rob him before he reaches the halfway hospital; they then lie in wait for him further down the road to relieve him of the money which he has just been receiving. Thus, what we spend is really encouraging the outlaw, and we are maintaining an endless chain of charity. I propose that, before spending any more money on the hospital, we endeavor to interest the authorities, and see if it is not possible to so police the road that no robbery will be possible upon it."

But when the Samaritan had made this speech, he was charged with being no better than a cold-blooded economist, and requested to leave the meeting.

This modernized parable may seem like a grotesque caricature of the facts. But let us examine, without prejudice and without fear, some of the conditions under 
which charity work is carried on in our country, before we say confidently that we do not maintain an endless chain of our own.

I shall not speak here of those elements in society which prey upon the community openly and avowedly, nor of the familiar vices and failings of human nature which are the cause of so much evil. I shall refer rather to those more subtle forces, which are often so fixed in our customs and our institutions that we hardly recognize them as thieves, and indeed should consider it uncivil to refer to them as such. As it is easy to pillory those beings which, having no ears cannot hear, and having no voices cannot talk back, I will mention first those bandits of the body which are responsible for most of our modern ailments and which, though they do not strip us of our raiment, often leave us half dead or entirely dead by the wayside of life. These bacilli, as they are commonly called, are of many kinds, and I need not distinguish among them. The bacillus of tuberculosis enjoys perhaps the greatest reputation on account of the extent of his depredations; but the bacilli of anthrax, of typhoid, of 
scarlet fever, are active according to their lights and their opportunities.

It is well known that most, if not all, of these robbers of health and efficiency thrive in crowded cities and houses. It is also known that they are especially favored by filth. Nevertheless, our country, as a whole, and our cities, in particular, are striving with might and main to increase, not the population bred from the old stock, but the immigrant population, and though we are well aware that this congestion brings new dangers to health, we make no adequate provision against the spread of disease. Let us take a concrete example.

In a city, not a thousand miles removed from the State of Connecticut, the robber bacilli have been found to be so active that a movement was inaugurated some years ago to put them in jail and try at least to diminish their depredations upon wayfaring men. In other words, it was proposed to establish an isolation hospital. The citizens were unanimously in favor of the project, in the abstract, but whenever it was proposed to give a local habitation as well as a name to this excellent idea, 
the people in the neighborhood of the proposed site regularly rose up as one man, and protested against its establishment on the ground that it would lower the price of real estate. The wise men of the city, after having vainly tried a number of sites, at last thought that they had found a solution of the difficulty, and decided to build a modern well-equipped establishment on the site of some hospital pavilions in which contagious diseases had been treated for years. Inasmuch as land in the neighborhood has steadily advanced in value and been embellished by the building of private houses, churches, stores and saloons, it was thought that the objection regarding the value of real estate would not apply. But the same cry arose again, and the hospital is still unbuilt. In the meantime, the demands upon voluntary charity and the burden of disease to the sufferers are increasing.

Let us look at a different phase of the subject. As a nation, we are justly proud of the development of our industries, of our railroads, and of our machinery. We encourage them by law. Certain industries seem so important that we lay a tax on the 
consumer in the form of a protective tariff in order to maintain them. Our patent laws encourage inventions. Our corporation laws encourage production on a large scale and give the investing capitalist the benefit of a limited liability. Our railroads enjoy the right of taking private property for their uses, and often of using the public highways. But all of these things lead to accidents, and many of them to disease.

In the year ending June 30, 1911, our railroads killed 3,519 passengers and employees, and injured 60,235. The employees naturally bore the brunt of this; 3,163 of them were killed and 46,802 were injured. ${ }^{2}$ Coal mining we know to be peculiarly dangerous. In 1908, 2,450 coal miners were killed and 6,722 injured in the United States. One man was killed for each 278 employed. We do not know how many persons were killed in all of the industries of the United States, but the State of New York has gathered figures for accidents in factories, quarries, and tunnel constructions, and in the single year 1909 there were 15,437 accidents, of which 258

2 Interstate Commerce Commission Report for 1911, p. 77. 
were fatal and 1,543 resulted in permanent injury. ${ }^{3}$ One of our most careful statisticians estimates the number of fatal accidents, among occupied males in the United States, as between 30,000 and 35,000 in a single year, and thinks that half of these are due to some industry. ${ }^{4}$ That this rate is terrible is obvious; that it is greater than it should be, is seen by comparing our figures with those of European countries. For instance, in the United Kingdom in 1904 , one man was killed on the railroads for 1,398 employed; in the United States, one man is killed for 385 employed. In Great Britain, one out of every 148 may expect to meet with some accident; in the United States, one out of every 30 . In coal mining the accident rate is more than twice as great as in the principal European countries. We kill one man for every $278 \mathrm{em}-$ ployed, while in Europe one for every 724 employed is killed. ${ }^{5}$ These accidents may

3 Gilbert Lewis Campbell: Industrial Accidents and their Compensation, 1911, pp. 9, 10.

4 F. L. Hoffman: Bull. of Bureau of Labor, Washington, Vol. XVII, 1908, p. 418.

5 Campbell, 1. c., pp. 10, 14, 16 and 17. The coal mining statistics refer for five European States to the year 1903, for twenty-two States of the United States to 1908. 
be fairly said to be the outcome of industries directly encouraged by law. They are well known. It would seem meet, therefore, that the same law which encourages the accidents should do something to diminish their prevalence. A few such laws have been passed, but they have been very slow in coming, and when they have finally been issued, they have, in a large number of cases, been found to conflict with the higher law of the constitution. Even when they have been sustained, it has cost the injured person much time and money to enforce his rights.

In 1893, Congress enacted a law requiring railroads to use, among other safety appliances, automatic couplers. On August 5,1900 , a brakeman by the name of Johnson was endeavoring to effect a coupling between a freight engine and a dining car, standing on a side track, and, while doing so, had his hand so badly crushed that it had to be amputated at the wrist. There was no question as to the intention of the law or as to the fact that the man had lost his hand. But there was a very serious question as to whether a dining car standing on a side track was engaged 
in interstate commerce, and until this weighty question could be settled, which took until December 10, 1904, Johnson could recover no damages from the railroad. Think of a man with his hand amputated, waiting four years for the lawyers to split hairs over such a question! This is not an isolated but a typical case. ${ }^{6}$

Another question occurs in connection with accidents. On whom shall the burden of the accident fall? An accident, by its very nature, is something unexpected. The individual cannot always be prepared for it. In the case of property, insurance has long been known as a device for spreading over a large group of interested persons the burden of the loss that may come from fire, explosion, or other sudden disasters. For a quarter of a century, people in other parts of the world have begun to realize the advantage, not merely to the individual, but to the community as a whole, of applying the same principle to accidents to workers, and have introduced some form of compulsory workmen's compensation, or of accident insurance, usually carried in the main by the industry, 6 Johnson vs. South. Pac. Co., 196 U. S., p. 2. 
or group of industries combined. The principle is not new in our country, as applied to sheep. If a farmer's sheep are killed by a dog, the selectmen can cause the owner of the dog to pay damages, or if they cannot find him, compensate the sheep's owner out of the public funds. Slowly the idea has gained ground in our country that a similar principle might well be applied to human beings and, after much discussion, a law was passed by the State of New York in 1910 designed to provide a moderate compensation to injured workers, even when no blame could be attached to the employers. The act was very carefully drawn, with a full knowledge of the constitutional breakers which lay ahead of it. It applied only to a limited number of occupations commonly recognized as extra-hazardous. This law was declared unconstitutional by a decision of the New York Court of Appeals handed down March 24, 1911, on the ground, among others, that it violates the XIVth amendment to the Federal Constitution.

As the decision was unanimous, it must be considered good law, and it would be foolish for a layman to express an opinion 
on the legal aspects of the case. But when the lawyer speaks of good law, he does not mean good legislation, still less good sense, or good economics. Now the economics of the decision is simply this: It is not competent for the legislature to pass a law throwing the burden of an accident upon the industry in which it arises, and requiring employers to treat the cost of medical attendance, sick allowance, etc., as they do the losses by fire and explosion. Therefore, the loss must fall either upon the victim himself or, if he has insufficient means, as is the common case, upon the charitable public or the taxpayer. In order that an obligation shall not be put upon an employer, "who has committed no wrong," a burden is laid upon those who have not only committed no wrong, but have no connection whatever with the accident, excepting as they live in the same state. Here is another case of the endless chain of charity work, created as the result of the application of constitutional law.

We can hardly blame the courts for this situation, since they are but following the law as they understand it. Nor can we blame the employers. As long as there is 
any reasonable doubt of the constitutionality of a law, they are morally obliged to subject every new enactment to the test of a lawsuit. Moreover, the best employers recognize a moral obligation far beyond that which any law imposes upon them; and in the whole movement for a more enlightened policy, they have borne an active and important part. The responsibility really rests with the people themselves, and with their political leaders. That is to say, it falls upon us all; because, rather than amend our constitutions so that they will clearly state what they mean, we persist in subjecting them to this constant strain, and thus, in the words of John Hays Hammond, have developed laws which, "to put it mildly, are a disgrace to our country."

Custom is often as strong as law, sometimes even stronger. We are all familiar with the tyranny of fashion. Women who would be too squeamish to crush a fly in their hands, will demand that others shall kill birds, even to the extermination of a species, to embellish their hats, if fashion

7 Address in Philadelphia, April 8, 1911, quoted in New-York Tribune, April 9, 1911. 
demands it. This tyranny of habit is recognized. It has often been the cause of injury to human beings as well as to birds, and the Consumers' League is organized for the express purpose of educating consumers to some thought for those who serve them, or who manufacture the goods that they use. Yet we have made comparatively little progress in this direction, and habit is playing its part in the endless chain of modern charities.

An example taken from recent experience will illustrate this point. It is well known that white phosphorus, commonly used in the manufacture of matches, is a poison which is liable to produce the terrible disease of phosphorus necrosis in the workers. It has also caused the death of many children who have ignorantly put matches into their mouths, and has frequently been used for criminal purposes. Altogether, it is a poison the use of which for many reasons it is desirable to limit and, if possible, abolish. In Europe it has been felt to be so dangerous that nine states have entered into an international agreement to prohibit white phosphorus matches. A bill aiming to accomplish this 
same purpose by a prohibitory tax was introduced into the Congress of the United States in 1910. The situation was peculiar in that this bill was endorsed, not only by the Association for Labor Legislation, which caused it to be drafted, and by the American Federation of Labor, representing the workers, but also by almost all of the manufacturers of matches, who recognized the danger and expressed themselves as quite willing to submit to an inconvenience, or even an increased cost of production, provided all were treated alike. When, however, the members of Congress were approached upon the subject, it was discovered that the bill was by no means sure of passage, and among other objections one prominently mentioned was that the consumers would not be satisfied with the substitutes. I procured matches made of sesquisulphide of phosphorus, which is considered to be one of the best substitutes for poisonous phosphorus, and undertook to demonstrate its effectiveness to a member of Congress by showing him how easy it was to light the match, not only on a rough surface, but even on a piece of comparatively smooth paper. He, however, at 
once took one of the matches and applied it to the seat of his trousers. It did not ignite. $\mathrm{He}$ had shrewdly detected the weak point of the substitute, and also the strong point of the opposition. For matches are used chiefly by smokers, and smokers, it seems, have a strong preference for lighting matches on the seats of their trousers. While the sesquisulphide match will light on almost any surface, and indeed can be lighted on the trousers seat, a good deal of pressure is needed to secure results. It is to be hoped that this objection may be overcome. Perhaps the tailors will gallantly come to the rescue of the girls who make matches and equip the seats of our trousers with a suitably roughened surface. Perhaps the quality of the match itself may be improved. Indeed, this has already taken place, and a New Jersey factory has successfully marketed a large quantity of the non-poisonous matches. In the meantime, it is a fact that the objection mentioned was a serious obstacle to the legislation in question and helped to delay its enactment until 1912.

This is not the only contribution made by the hajits of smokers to the endless 
chain. We have not yet, I hope, forgotten the terrible fire of 1911 in New York, in which 145 workers in the Triangle shirtwaist factory met a shocking death. According to statements made by the authorities who investigated it, but one cause of the fire was discovered, and that was cigarette smoking; yet it is remarkable that, at least in the newspapers which have come to the attention of the writer, no blame seems to be attached to the smokers, but all of the blame is thrown upon the employers and the builders. Several fires have occurred in the Yale grandstand at the time of the annual football game, all due to the habits of smokers, and panics have been avoided only by vigilance on the part of the watchmen. But here again no one seemed to think that it might be possible for smokers to have sufficient regard to the rights of the public to extinguish their matches, cigars, and cigarettes before they throw them down. In New Haven in the single year 1910 the fire department was called out forty-nine times by fires clearly attributable to smokers, apart from the large number caused by matches, some of which were doubtless used by smokers. 
In Massachusetts 111 forest fires, involving a loss of $\$ 33,000$, were started by smokers in 1908, and, next to locomotive sparks, tobacco was the most prolific of the ascertained causes of forest fires in that State. ${ }^{8}$

Indeed, our custom actually raises smokers to the position of a privileged class. They are the only people who can get two seats in a drawing-room car by paying only one fare; and for their sake our railroads must supply more seating room than they can sell.

Many seem to consider the right to smoke anywhere and everywhere one of the fundamental rights of man. A city legislator recently asserted his right to smoke in the public sessions of the Board of

8 F. W. Rane: We Must Stop Forest Fires in Massachusetts, 1909, pp. 7-9. Official figures regarding forest fires caused by smokers are inevitably understatements, on account of the difficulty of obtaining conclusive evidence. Hence in a large number of cases the cause is put down as "'unknown." Referring to fires caused by smokers, hunters, etc., Mr. Rane says, in his Seventh Annual Report as State Forester of Massachusetts: "There is no doubt that most of the fires labelled 'unknown' would be placed in this column if they could be traced out; so that we feel sure that they cause as many fires as the railroads, and are more dangerous, because the smoke is everywhere"' (pp. 47-48). 
Alderman. A New York newspaper has called attention to the dangers which come from eigarette smoking in the lobbies of theaters, not on the part of red Indians but on the part of men who carry gold cigarette cases. With such examples, can we wonder that shirtwaist cutters consider it one of the rights of American citizens to smoke when at work, and that our smoking habits make no small contribution to the endless chain of accidents and hospital cases?

"O God, that men should put an enemy in their mouths to steal away their brains!" The robber alcohol is familiar to us all, but we do not always realize the extent of his robberies. Some years ago a committee of fifty was formed for the express purpose of studying the liquor problem in its various aspects. One of its sub-committees made a study of its economic aspects. With the aid of a large number of societies, prison wardens, and other persons, it tried to find out how many persons had committed crime or had fallen into dependence as the direct or indirect result of the use of alcohol.

The investigation was made with the 
greatest care by a study of individual cases, and was nothing if not conservative. Yet it appeared that, of the poverty coming within the field of charity organization societies, 25 per cent could be traced directly or indirectly to liquor, while in almshouses 37 per cent was so traced and not less than 45 per cent of the destitution of children in institutions was due to the liquor habits either of the parents, guardians, or others. ${ }^{9}$ In the case of crime, a distinction was made between primary and secondary causes, and while in 31 per cent of the convicts investigated, liquor was found to be the primary cause, it figured as a cause more or less important in nearly 50 per cent. ${ }^{10}$ There is no doubt of the ravishes of this thief, who not only steals away our brains, but robs wives and children of their support, and fills our prisons and almshouses. I am well aware of the difficulty of dealing with this question. The very magnitude of the liquor interest makes it a powerful political agency which it is not easy to overcome. And yet in Con-

9 John Koren: Economic Aspects of the Liquor Problem, Houghton, Mifflin and Company, 1899, pp. 21, 22. 10 l. c., p. 30. 
necticut we put the control of this dangerous traffic into the hands of a small body of persons, who are so appointed that they have no direct responsibility either to the electors or to any single administrative officer, and who are practically exempt from the ordinary checks and balances of a republican form of government. We need not wonder that a law limiting the number of saloons can remain a dead letter, and that it is not possible to make anyone responsible for its enforcement.

The hospital for the confinement and treatment of contagious diseases must wait years for its realization, but establishments for the distribution of liquor hold what is virtually a position of privilege. Is not the community as a whole contributing through this policy to maintain the endless chain of poverty and distress?

In calling attention to these evils, I disclaim the intention of attacking any person or group of persons. The citizens as a whole, and, I do not hesitate to say, more particularly the property owning classes, are responsible for a system which creates constantly new demands upon their charity. Like an inexperienced bicyclist breast- 
ing his first hill, who pushes with both feet at once, we create with one hand the evils which the other is trying to remedy. We are so anxious for gain that we do not realize what it costs us to conduct our business. The same gold "gilds the straightened forehead" of us all.

These illustrations, which do not begin to exhaust the subject, are intended to show that, while much of the distress and the evil that charity tries to relieve is due to human nature, heredity, and other causes, which are very difficult to reach, much of the work that it is called upon to do is the direct result of institutions, laws or customs maintained with a short-sightedness that would be incredible, were we not so inured to it that we are hardly conscious of any defect in our social vision. But as long as an ounce of prevention is worth a pound of cure, and as long as it is kinder to prevent a person from falling into a ditch than to pull him out after he is in, so long will our work be incomplete, and indeed futile, unless we realize that the Good Samaritan must at the same time be a good citizen. 


\section{CHAPTER XII}

\section{Signs of a Better Social Vision}

To provide altruism with social spectacles means a great deal. It means that the effective charity worker will not content himself with the customary methods of relieving distress. He must sometimes suppress the impulses of his heart, if he knows that he is liable to do harm by yielding to them. He must also take such part in securing legislation, in influencing administration and policy, and in helping. to guide public opinion, that the causes of poverty and sickness will be undermined. Fortunately we are already seeing evidence of sporadic individual efforts made in the direction indicated. What is needed is to co-ordinate them, help them to pull together, make them conscious of each other; in short, we want more team play. A few illustrations will make this clear.

Not only accidents but many diseases are caused by certain industries. We are just beginning the study of these matters. Italy has established, in the city of Milan, 
a special hospital for the treatment and study of industrial diseases with the aim of diminishing them. This is a branch of what is called preventive medicine. It points the way to the future, and I have no doubt that our country will soon learn the lesson that Italy and other countries are teaching us, and apply it to our conditions.

Still other diseases are due, as we know, to the conditions of living in our large cities. This is particularly the case with regard to tuberculosis. Some years ago a student in the Yale Medical School made a map of New Haven, showing the cases of consumption by means of red dots, and the map showed such an eruption of this rash in certain streets and houses, that those who were responsible for the study did not dare to have it published. We are slowly awakening to the importance of air and light. The AntiTuberculosis Association does not content itself with treating cases, but aims to educate the public through its graduates. We have but one tenement law on the statute books of Connecticut, but there is a movement to make this law more stringent, and the organization, in 1910, of a National 
Housing Association is calculated to give intelligent direction to the movement for better housing conditions which is growing up all over the country.

The psychical and social causes of disease are at last being recognized. Under the leadership of the Massachusetts General Hospital Society, a number of our hospitals, including the New Haven Hospital, have added a social feature to their work. We are now realizing that it is not enough to give the patient medical treatment; we must also try to reach the social causes of disease. Modern medical schools now have chairs of preventive medicine. The professor who was called upon to fill that chair in the new medical school of St. Louis prepared himself for his work by studying, not merely chemistry, physiology, and anatomy, but by examining our factories and our tenements, and consulting with economists and sociologists.

An illustration of the importance of economic considerations in the profession of medicine was brought out recently by Dr. Lyman of the Gaylord Farm Sanatorium. Looking at the matter from the strictly medical point of view, a patient recovering 
from tuberculosis should live an out-ofdoor life, and take up some occupation which secures this. An actual study of cases has shown, however, that in general those patients maintain their improvement best who go back to their old occupations, not because these are medically desirable, but because they furnish a better support and are better adapted as a rule to the abilities of the patients than are out-ofdoor occupations, which usually involve undue exertion or great physical strength.

New forms of public activity are being developed. The social settlements, the Consumers' Leagues, the George Junior Republics, the Society for Mental Hygiene, the visiting nurses and housekeepers, the Boy Scouts, are examples of efforts made, not to exercise, but to forestall charity.

Even our nomenclature is changing. The expression "social service" is supplanting the word "charity." The magazine formerly known as Charities is now called The Survey, and it was under its direction that the remarkable study of industrial conditions, known as the "Pittsburgh Survey," was made a few years ago. People who wish to go into social work are now 
receiving training in special schools, sometimes called schools of philanthropy, but more appropriately, as in the case of the Chicago school, named schools of civics and philanthropy. Science and charity are no longer strangers, but are working hand in hand.

In short, we are beginning to realize, in the words of Dr. Cabot, that, "Science without humanity becomes arid and, finally, discouraged. Humanity without science becomes scrappy and shallow.",

We thus need to unite all of the agencies, whether philanthropic, scientific, or civic, whose activity may diminish or relieve distress. The suggestion, made by Mr. Kellogg at the Connecticut Conference of Charities and Correction held in 1910, that we should have more charity organization societies in Connecticut, is worthy of serious consideration. We not only need more societies, but we need to organize them on a broader basis, and to have a greater coordination between those in different cities. A preliminary step toward such a broader understanding lies in a knowledge of the

1 Richard Clarke Cabot: Social Service and the Art of Healing, 1909, pp. 30, 31. 
facts. It is strange that, although so many people are interested in these subjects, and so much money is annually contributed, no one has more than a very vague knowledge as to the total amount which is spent, either in the State or in any one city of the State, during a given year. As a step toward supplying this need, and at the same time emphasizing its existence, the Organized Charities Association of New Haven has attempted a directory of local societies, and a summary of their financial condition. It is not complete, and absolute accuracy in such matters is perhaps unobtainable, but it is hoped that it will at least give some facts of general interest and stimulate other societies to follow our example. It is significant that this piece of work was planned by the directors of the society and executed by a divinity student under the direction of a professor of political economy.

Some people are afraid that organization will make charity too mechanical and impersonal. There is danger of fossilization in any form of public service, but it is not greater in the new era, which I believe to be dawning, than it has been in the past. 
Could anything be less personal than dropping a copper into the hat of a beggar? This form of charity is as mechanical as is the "wheezer" hand organ, whose doleful notes are studiously designed by the manufacturer to work upon the sympathies of the passer-by. The new charity makes greater demands upon the individual, because it requires thought and work as well as sympathy and doles. It demands a social imagination strong enough to apprehend not only what we see with our eyes, but what we do not see. It requires us to look at future as well as at immediate results. It is optimistic because it hopes, not without good reason, to be able to diminish as well as relieve distress. It demands the co-operation of many professions. It enlists in its campaign the lawgiver, the engineer, the physician, the economist, the statistician. It is substituting the trained expert for the amateur. It is insisting that philanthropy shall be farsighted as well as kind. It even expects that this far-sightedness will in the future influence our business activities, as well as conventional charity. 


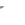




\section{INDEX}

Abbe, Ernst, birth and education, 139; founds CarlZeiss-Stiftung, 142; Gesammelte Abhandlungen, 138; life shortened by overwork, 162 ; member of board of Zeiss-Werk, 146; on eight-hour day, 157; on profit-sharing, 154; on relations of employees to establishment, 146, 147; principle of trieder binocular applied by, 141 .

Acatallactic, definition of

Accidents, burden of, $95,174-176$; caused by industries, 187 ; compensation for, 70, 71; compulsory insurance for, 134; deaths from industrial, in Pittsburgh, 102; encouraged by law, 173; in coal mines in U. S., 171; in New York State, in factories, quarries and tunnel construction, 171; insurance against, 70; need for fuller records of, 99, 111; new causes of, 70 ; number of, in U. S. compared with Europe and Great Britain, 172; on railroads in U. S., 171; preventable, 3, 73; problem of labor legislation to diminish, 70; social causes of, 3 ; treaty for compensation for, 71.

Administration, experimentation through ....... 38

Aërial navigation $\ldots \ldots \ldots \ldots \ldots \ldots \ldots \ldots \ldots \ldots 6$

Agricultural experiment stations $\ldots \ldots \ldots \ldots \ldots \ldots 65$

Agriculture, application of science to, 64, 65;

methods of, 42 ; schools of, 65 .

Aimes, Hubert H. S.

Alaska, 98; instructiveness of history of, 48, 49 .

Alcohol, crimes committed as result of, 183, 184;

poverty caused by use of, 183, 184.

Allison Act $\ldots \ldots \ldots \ldots \ldots \ldots \ldots \ldots \ldots \ldots \ldots$

Altruism, needs social spectacles, 187 ; spirit of, 165. 


\section{INDEX}

American Association for Labor Legislation, 82, 119, 121 ; advocates reporting of industrial diseases and accidents, 111; and lobbying, 119; drafts phosphorus bill, 179; study of administration of labor laws by, 117.

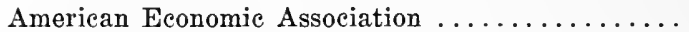

American Federation of Labor, endorses phosphorus

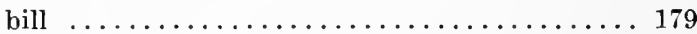

American Historical Association ........... 53

American History, Turner's Social Forces in...... 53

American Industrial Society, Documentary History of 51

Amonn, Alfred ...................... 30

Anarchist, philosophical .............. 48

Annuities, distribution of wealth by ......... 124

Anti-Trust Law ..................... 15

Anti-Tuberculosis Association ............. 188

Anthracite coal strike ................ 19

Arbitration, compulsory, 85, 135; voluntary, 85 .

Aristotle ....................... 23

Artificial selection $\ldots \ldots \ldots \ldots \ldots \ldots \ldots \ldots \ldots \ldots 6 . \ldots \ldots$

Associations, co-operative .............. 85

Astronomy and deduction .............. 11

Auerbach, Felix ................... 138

Australia, wage boards and compulsory arbitration

systems in ..................... 135

Automatic couplers, law requiring, on railroads ... 173

Babcock tester .................. 127

Bargaining, collective, joint boards for, 85 ; new machinery necessary for, 69.

Bellamy Clubs

Benefit societies, 85; in Switzerland, 113.

Bimetallic theory ................. 15

Blackstone, on requisites to good government, 104;

opinion of British Parliament, 104.

Books, property right in, enforced by law ...... 127

Boy Scouts ........................ 190 


\section{INDEX}

British Association for Advancement of Science.... 26

Brodsky, R. J., insurance in fraternal and benefit societies ...................... 113

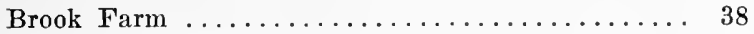

Brooks, Robert C. ................. 16

Budgets, of elubmen, 48; family, 23; of workingmen 48

Buffalo, adaptation of, to environment .......58, 59

Business, artificial stability of, ereated ........ 71

Cabot, Dr. Richard Clarke, "Social Service and Art

of Healing", .................. 191

Campbell, Lewis Gilbert, on industrial accidents ... 172

Canada ....................... 37

Capital, benefited by changes in organization, 71;

government intervention to save deterioration of human, 71; increase in, 68, 69; law putting new responsibilities upon, 71 ; legal privileges of, 24 ; legal restrictions on, 24.

Capital contract, forms of . . . . . . . . 130-132

Carl-Zeiss-Stiftung, see Zeiss-Stiftung.

Carnegie, Andrew, 163 ; on hereditary wealth, 45.

Carnegie Institute .................... 101

Carnegie Institution of Washington ......11, 50, 65

Caste system ......................... 78

Changes, in consumers' wants, 68, 71, 72; in methods of organization, 68,71 ; in methods of production, $68,70,71$.

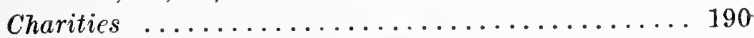

Charities, directory of, in New Haven ........ 192

Charity, 177-186; condition under which it is carried on, 167, 168; demands of new, 193; examples of efforts to forestall, 190; fear that organization will make impersonal, 192, 193; ignorance of amount spent on, 192; private, 63; team work needed in, 187 ; working hand in hand with science, 191.

Charity worker, the effective ............ 187 
Chicago school of civies and philanthropy ....... 191 Children, argument for protecting, 94; destitution of, caused by liquor habits of parents, 184; effects of machinery upon, 70 ; lack of adequate laws for protection of, 98, 107; law limiting age of employment of, 84, 88; law limiting hours of employment of, 84, 88; playgrounds for, 97 ; views of Alexander Hamilton on labor of, 79 .

China

Cigarette smoking, cause of Triangle shirtwaist fire, 181 ; in lobbies of theatres, 183.

City and Suburban Homes Conıany .

Civilization, by-products of, 63 ; effects of, upon nature, 58, 59; hunting stage of, 60.

Civilized man and struggle for supremacy over nature .....................58-60

Civies, schools of $\ldots \ldots \ldots \ldots \ldots \ldots \ldots \ldots \ldots 19 \ldots \ldots \ldots$

Civil Service examination for factory inspectors ... 117 Clark, J. Maurice ................... 39 Clark, Prof. John Bates, on elements of economic progress ....................68-72

Coal mining, accidents in the U. S. in ........ 171

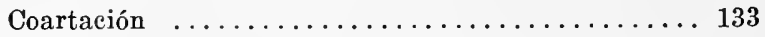

Collective bargaining $\ldots \ldots \ldots \ldots \ldots \ldots \ldots \ldots, 85$

Collectivism ................... 96

Colonies, British, compared with the U. S. ...... 37

Commission, President's Anthracite Coal, 20; expert 100 Committee of Fifty on the Liquor Problem ...9, 183, 184 Committee on Public Health ............. 106

Common law, re-enacted in Massachusetts ....... 114 Commons, Prof. John R. .............. 51

Compensation, workmen's, see workmen's compensation.

Competition, free, considered as a cure for the abuses of trade, 15; limitation of, 135.

Compromise of $1850 \ldots \ldots \ldots \ldots \ldots \ldots \ldots \ldots$ 
Compulsory arbitration ............. 135

Compulsory insurance, 90, 108; in Germany, 79, 92, 134; laws regarding, 84; of sick in ZeissStiftung, 147, 149; see also workmen's insurance.

Concomitant variations, method of $\ldots \ldots \ldots \ldots .6,13$

Connecticut, Conference of Charities and Correctiun, 191; control of liquor traffic in, 185; inexperi. ence of legislators in, 105 ; isolation hospital in city in, 169, 170; tenement house law of, 188.

Conquest, law of

Conservation, 97 ; labor legislation part of movement for, 80,81 ; societies relating to, 39 .

Constitution, Federal, 77, 103; laws to diminish accidents found to conflict with, 173; New York State Workmen's Compensation act violates XIVth amendment of, $175,176$.

Constitutions, amendment of $\ldots \ldots \ldots \ldots \ldots 109,177$ Consumers' Leagues, 190; purpose of, 178.

Consumers' wants, ehanges in $\ldots \ldots \ldots \ldots \ldots 8,71,72$ Contract, capital, forms of, 130-132; labor, 62 ; labor, in Zeiss-Stiftung, 149, 150; law of, 62 ; legal form of, influences machinery of production, 130-137; terms read into, by law, 134; wage, 85 , 132-135.

Co-operation, productive $\ldots \ldots \ldots \ldots \ldots \ldots \ldots \ldots 136$

Co-operative associations $\ldots \ldots \ldots \ldots \ldots \ldots \ldots .85$

Corporation laws, encourage production on large scale ........................ 171

Corporations, public service, 39 ; records of, 50 ; regulation of, 36 .

Courts, power of, to nullify laws interrupts experi-

mentation in U. S. . . . . . . . . . . 49

Crimes, due to alcohol $\ldots \ldots \ldots \ldots \ldots \ldots \ldots \ldots 183,184$

Cross, Prof. Ira B. . . . . . . . . . . . . 39

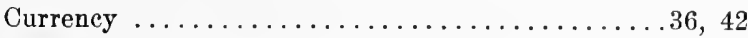

Custom, often as strong as law .......... 177 
Czapski, Siegfried .............138, 142, 162

Davenport, Dr. C. B. ................ 46

Decadence, national ................ 48

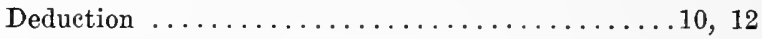

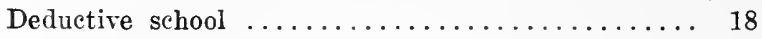

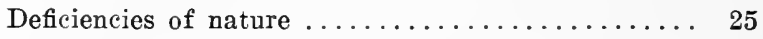

Degeneracy, human ................. 25

Description, contrasted with science.........53-54

Dewey, Prof. Davis R., presidential address of .... 51

Diminishing returns, law of ............. 24

Discoveries, eagerness with which pursued, 66 ; readiness to use, as basis of property rights, 66 ; tendency to anticipate, 65,66 .

Disease, economic ................25, 26

Diseases, attempt to reach social causes of, 189; caused by conditions of living in cities, 188, 189; hospital for industrial, in Milan, 112, 187, 188; industrial, 70 ; lack of information regarding industrial, 99 ; national investigation of industrial, urged by American Association for Labor Legislation, 111 ; preventable, 73 ; psychical and social causes of, 189; study of industrial, 187, 188.

Distribution of wealth, 24; by gift, 124; by graft, 125 ; by law, 124 ; by marriage, 124 ; by will, 124; not as simple as was once assumed, 122 ; without reference to law of supply and demand, 123-126.

Distributive or positive labor legislation, 84, 85, 89-91 Documentary History of American Industrial Society 51

Documents, State economic, index of ........ 50

Domestication, stage of $\ldots \ldots \ldots \ldots \ldots \ldots \ldots 60$

Drafting, necessity for careful, in legislation, 115; society for, 116.

Dynamic society, Clark's elements of ........68-72 
Economic conditions, retard good legislation ..... 100

Economic experimentation, advantages of the U. S. for, 34-42; contrasted with observation, 13 ; disadvantage of economist in, 49 ; ethical difficulties of, 1-4, 13; favorable conditions for, in U. S., $37-42$; fields of, $42-49$; hindered by inadequate records, 50-52; interfered with in the U. S. by the courts, 49; John Stuart Mill on, 5-7; logical objections to, 4-6; objections to, discussed, 6-10; referred to by Ely, Keynes, and von Schmoller, 27; referred to by Newmareh and Jevons, 26; through legislation and administration, 38 ; tried in self-interest, 39 ; views of economists regarding, discussed, 28-31; wage receivers and, 40.

Economic forces, operation of $\ldots \ldots \ldots \ldots \ldots \ldots \ldots 53$

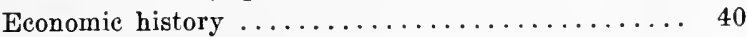

Economic ideal of U. S. . . . . . . . . . . 77-80

Economic interests, 34 ; and political questions, 36.

Economic interpretation of history contrasted with economic utilization of history $\ldots \ldots \ldots \ldots \ldots, 52$

Economic laboratory, conception of history as .... 52

Eeonomic laws ................23, 28, 29

Economic nuaterial, 33 ; buried in state archives, 50.

Economic pathology ............... 25, 48

Economic phenomena, analysis of .......... 24

Economic processes, influenced by legal or institu-

tional factors ................... 124

Economic progress, Clark's elements of, 68-72;

involves labor legislation, 73 ; spirit of, 64.

Economic questions in the history of the U. S. . . . 36

Economic reactions, study of $\ldots \ldots \ldots \ldots \ldots \ldots 46,47$

Economic results of laws, importance of recording. . 52 Economic science, Jevons' contribution to, 28 ; scien-

tific management applied to, 32 ; two phases of, $55,56$.

Economic system, pathologic state of .......... 
Economic theory, Professor Ely's views on ........

Economic utilization of history contrasted with economic interpretation of history ............

Economies, laws of, 52 ; of decision against $\mathrm{New}$ York State workmen's compensation law, 176.

Economist, disadvantages of, in experimentation, 49; qualities needed by, 56 ; task of, 22.

Economists, Italian, 31 ; point of view of, contrasted with that of historians, 53 ; reliance of Federal and State governments upon trained, 51 ; theories of, and economic experiments, 15 .

Ehrich, Louis R. ................. 96

Eight-hour day, in $Z$ eiss-Stiftung . .......156, 157

Ely, Prof. Richard T., 27; on relation of labor legislation to economic theory, 82 .

Employers' liability laws, 84 ; recognize moral obligations, 177 ; relation of, to employed weakened, 69.

Endless chain of charity, contribution of alcohol to, 183,184 ; contribution of habit to, 177-186; contribution of habits of smokers to, 178-183; created as result of application of constitutional law, 176; responsibility for, 177, 185.

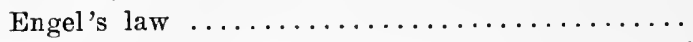

England, 37 ; average duration of life in, 72 ; experi-

ence in posteritism in, 97 ; forms of wage contracts in, 133.

Eugenies, 97 ; not yet an exact science, 73 .

Europe, experience in posteritism, 97 ; history of, compared with U. S., 34, 35; number of accidents in, compared with U. S., 172; under compulsory insurance laws, 134.

Evils, connected with efforts to improve social institutions, 61.63 ; due to changes in methods of production, 70 ; of progress, legislation necessary to prevent, 68 . 


\section{INDEX}

Exchange, terms of, affected by distributive legislation ......................... 85

Experiment station, advantage of U. S. as ....... 37

Experimental evolution, laboratory of ........ 11

Experimental method, see economic experimentation.

Explorations, polar, and the press ........65, 66

Factories, accidents in, in New York .......... 171

Factory inspectors, Prussian requirements for, 117,

118; qualifications for, 116, 117.

Factory system, 70; advocated by Alexander Hamilton, 79.

Fairview Colony of Single Taxers .......... 38

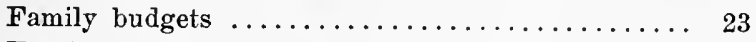

Fashion, tyranny of $\ldots \ldots \ldots \ldots \ldots \ldots \ldots \ldots \ldots \ldots \ldots \ldots$

Favors, distribution of wealth by special ........ 125

Federal Constitution ........77, 103, 173, 175, 176

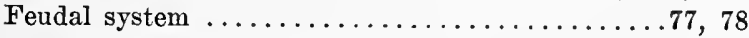

Fires caused by smokers $\ldots \ldots \ldots \ldots \ldots \ldots \ldots \ldots 1$

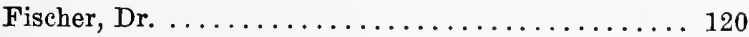

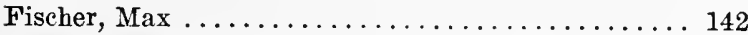

Fisher, Prof. Irving $\ldots \ldots \ldots \ldots \ldots \ldots \ldots \ldots$. 73

Forces prominent in European history ........ 34

Forest fires in Massachusetts caused by smokers ... 182

Forests, measures for preserving . ......... 97

France, labor unions in, 92 ; treaty for compensation

for accidents between Great Britain and, 71 .

Free competition, and the Anti-Trust law ....... 15

Free passes on railroads .............. 125

Freehold, preferred in New England to feudal land

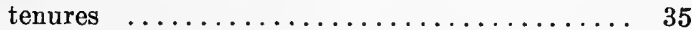

Fugitive Slave Law ................ 36

Galileo ...................... 54

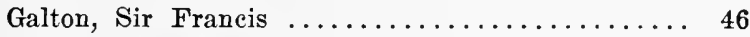

Gaylord Farm Sanatorium ............. 189

George Junior Republic . . . . . . . . . . . . 190

German historical school ............. 27-30 


\section{INDEX}

Germany, compulsory insurance in, 92, 134, 147; compulsory sick insurance in, 79 ; historical school of, 12, 27-30; labor unions in, 92 ; railroads of, compared with those of U. S., 128; system of old age insurance in, 114.

Ghent, system of insurance against unemployment in 92

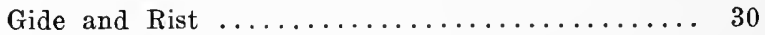

Gifts, distribution of wealth by .......... 124

Good Samaritan, parable of, 165; sequel to parable of, 166,167 ; should be a good citizen, 186.

Government, intervention of, to save deterioration of human capital ............... 71

Graft, a cause of unequal distribution of wealth ... 125

Gratuities .................... 133

Great Britain, number of accidents in, compared with

those in U. S., 172; treaty for compensation for accidents between France and, 71 .

Gresham's law, analogy of, applied to labor problems 86 Guernsey, prosperity of island of, attributed to

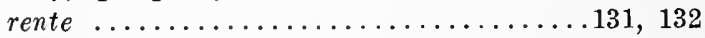

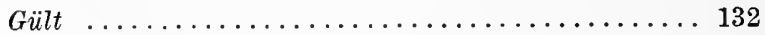

Habit, contribution of, to endless chain . . . . 177-186

Hale, Dr. George E. ................ 11

Hamilton, Alexander, views of, on child labor ..... 79

Hammond, John Hays ............... 177

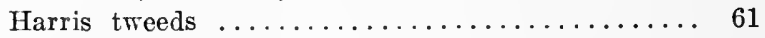

Hereditary wealth, Andrew Carnegie on ........ 45

Heredity .................. 31, 45, 46

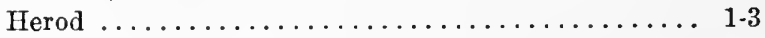

Heterogeneity of people of U. S. . ......... 41

Historians, point of view of, contrasted with that of

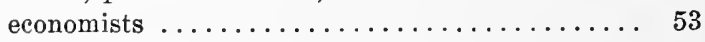

Historical Association, American ........... 53

Historical facts, scientific value of ......... 32

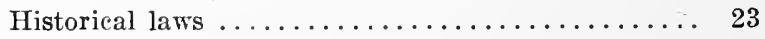

Historical method ............... 29 
Historical school, German ...........12, 27-30

Historiometry ......................... 31

History, conception of, as economic laboratory, 52;

dynamic period of world's, 64; economic, 40, 54;

economic interpretation of, contrasted with economic utilization of, 52 ; law of, 52 ; social forces in American, 53.

History, Documentary, of American Industrial Society ........................ 51

Hoffinan, Dr. F. L., accident statisties . . . . . . 172

Homestead exemption laws $\ldots \ldots \ldots \ldots \ldots \ldots \ldots .78$

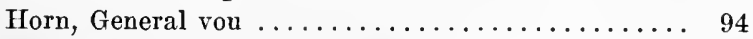

Hospilal, for industrial diseases in Milan, 112, 187,

188; isolation in Connecticut, 169, 170, 185;

Massachusetts General, 112, 189; U. S. compared to $a, 37$.

Hours of labor, in Zeiss-Stiftung, 148, 155-158; laws imiting, of children, 84,88 .

Housing conditions, movement for better, 189 ; tuberculosis caused by unsanitary, 188.

Human life, average duration of $\ldots \ldots \ldots \ldots \ldots .72$

Human serap heap ................... 102

Ideal, economic, of U. S. .............. 77-80

Idleness, voluntary $\ldots \ldots \ldots \ldots \ldots \ldots \ldots \ldots \ldots 48$

Imagination, scientific, 23 ; social, 166.

Immigration $\ldots \ldots \ldots \ldots \ldots \ldots \ldots \ldots \ldots \ldots \ldots, 69$

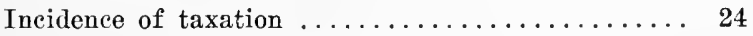

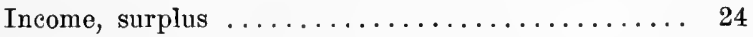

Increment, unearned, taxation of $\ldots \ldots \ldots \ldots \ldots \ldots 16$

Indentured labor .................43, 132

Index of State economic documents .......... 50

Individualism, not the only antithesis to socialism, 95, 96

Industrial accidents, see accidents.

Industrial diseases, see diseases.

Industrial organization, new forms of ....... 39

Industrial poisons, list of $\ldots \ldots \ldots \ldots \ldots \ldots \ldots$ 


\section{INDEX}

Insurance, accident, 70, 134; compulsory, 84, 90, 92, $108,134,147,149$; in benefit societies in the U. S., 113 ; in Germany, $79,114,134,147$; in Zeiss-Stiftung, 147, 149, 150; invalidity, 134; investigation of, in New York, 125; of aërial risks, 66 ; of old age in Germany, 114; of sick in merchant marine of U. S., 79; of sick in Switzerland, 113; unemployment, 92; workmen's, 70.

Interest, affected by law or custom, 123; rate of, 42 ; rate of, in Wall Street, 126.

Interests, economic, 34; and political questions, 36. International Association for Labor Legislation, 71; application of practical principles by, 119, 120; Bulletin of, 120.

International treaties $\ldots \ldots \ldots \ldots \ldots \ldots \ldots$

Interpretation, economic, contrasted with economic utilization of history $\ldots \ldots \ldots \ldots \ldots \ldots \ldots, 52$

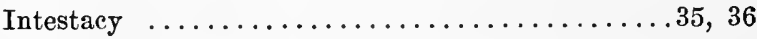

Invalidity, compulsory insurance against ....... 134 Inventions, encouraged by patent laws, 171; policy of Zeiss-Stiftung regarding, 158, 159; property right in, 127.

Investigations, Committee of Fifty, on Liquor Problem, 183, 184; New York insurance, 125; Sage Foundation, of salary loan business, 126.

Irrigation $\ldots \ldots \ldots \ldots \ldots \ldots \ldots \ldots \ldots \ldots \ldots \ldots \ldots \ldots$ 81, 97 Italy, hospital for industrial diseases in . .112, 187, 188 Jena, University of, 145, 164 ; confers degree on Carl

Zeiss, 142; gifts of Zeiss-Stiftung to, 159, 160. Jevons, W. Stanley ...........15, 16, 26-28, 37 Johnson vs. Southern Pacific Railroad Company, 173, 174 Kellogg, Charles P. . ................ 191 Keynes, John Neville .............27, 28, 30

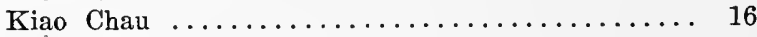
Knies, Karl .................... 29 


\section{INDEX}

Labor, application of free, 43 ; child, 88 ; effect of, on production, 44 ; experiments in efficiency of, 43 ; hours of, in Zeiss-Stiftung, 155-157; indentured, 43, 132; legal status of, 24; methods of applying, to land, 43 ; new standard of, created, 88 ; organization of, 36 ; problems affecting, 5 ; reaction of wealth upon efficieney of, 44 ; skilled, 70.

Labor contract, 62 ; forms of, 132-134; in ZeissStiftung, 149, 150.

Labor laws, administration of, 117; lien, 134; "'master and servant," obsolete expression in, 69 ; necessity for recording operation of, 118; number passed in U. S. in 1907, 98; Prussian child, 94 .

Labor legislation, aims to distribute wealth, 95 ; aims to preserve race, 94; American Association for, see American, etc.; analogy to monetary legislation, 86-92; elasses of, 83-93; conservation and, 80,81 ; consistency given to, 79,80 ; distributive or positive, $84,85,89-91$; economic progress involves, 73 ; grouped as socialistic, 95 ; history of, shows dangers in distributive legislation, 90 ; International Association for, see International, etc.; interstate and international needed, 71 ; less frequently expressive of class feeling, 76 ; necessary to prevent evils of progress, 68 ; necessity of careful investigation of facts in, 111 ; number of laws passed in 1907 in U. S., 98; permissive, $85,86,91,92$; problems of, 70,71 ; promptness of, 75; protective, $84,86-89,94,97$; purpose of, 94; recognition of, as permanent feature, 76 , 77 ; requisites of, 111 ; societies relating to, 39 ; subject for international treaties, 99 ; uniformity of, 76; views of Professor Ely on relation of, to economic theory, 82 . 
Labor organizations, laws regulating $\ldots \ldots \ldots \ldots . \quad 85$

Labor problems ................... 43

Labor unions, 91,92 ; records of, 50.

Labor welfare, Zeiss-Stiftung and ......... 158

Laboratory, economic, conception of history as ... 52

Laboratory methods ................ 49

Laborers, premature death of ........... 103

Laissez faire, 83 ; argument for, 110; doctrine of, 83. Land, methods of applying labor to, 43 ; public policy of U. S. in regard to, 78 .

Land tenure, 24, 42; societies relating to, 39 .

Lands, public, 36 ; policy of U. S. in regard to, 78 .

Law, affecting economic relations, 51, 52; Anti-Trust, 15; common, re-enacted in Massachusetts, 114; distribution of wealth by, 124; endless chain ereated as result of application of constitutional, 176; Fugitive Slave, 36; immutability of, 74; limiting number of saloons a dead letter, 185; made for man, 110; New York State workmen's compensation, declared unconstitutional, 175,176 ; of conquest, 62 ; of contract, 62 ; of diminishing returns, 24 ; of pendulum, 54 ; of supply and demand, operation of, limited by noneconomic forces, 126-136; putting new responsibilities upon capital, 71 ; tenement house, in Connecticut, 188 ; terms read into contracts by, 134.

Law schools, science of legislation absent from cur-

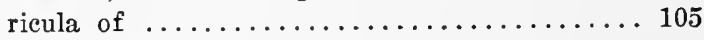

Laws, administration of, 98,117 ; compensation, in conflict with constitution, $173,175,176$; compulsory insurance, 90 ; corporation, encourage production, 171; early, economic ideals of, 35 ; economic, 23, 28, 29, 52; employers' liability, 84 ; examples of distributive or positire, $84-86$; examples ( $\mathbf{f}$ permissive, 85,91 ; examples of pro- 


\section{INDEX}

tective, 84, 88; historical, 23; homestead exemption, 78; importance of recording economic results of, 52 ; labor lien, 134 ; lack of, for protection of women and children, 98, 107; limiting age and hours of employment, 84, 88; monetary circulation, 86, 87; more uniform needed, 76 ; of Medes and Persians, why immutable, 74; patent, 127, 171; power of courts to nullify, interrupts experimentation, 49 ; provision for execution of, 116 ; scientific, 22,23 ; statistical, 23 ; study of operation of past, 83 ; tenement house, $69,188$.

Legislation, American Association for Labor, see American, ete.; compared to surgery, 110; economic conditions retard good, 100; effects of careless, 107; experimental, 28; experimentation through, 38 ; hampered by constitution, 108, 173, 175,176 ; lobbying for, 119 ; necessary to prevent evils of progress, 68 ; necessity for careful drafting of, 115; necessity for study of pre-existing, 114 ; need for, in case of overexertion and unemployment, 72; product of unskilled labor, 106; provision for execution of, 116 ; restrictive, the condition of economic freedom, 81; social, 28; see also labor legislation.

Legislative Reference Library of Wisconsin ...... 100

Legislators, lack of training of, in U. S. ...99, 100, 105

Legislatures, need economic annex for recording

results of laws $\ldots \ldots \ldots \ldots \ldots \ldots \ldots \ldots \ldots, 52$

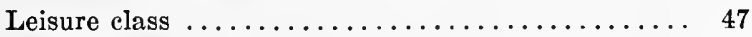

Lex Rhodia de jactu ................... 108

Life, average duration of human .......... 72

Liquor, crimes committed as result of, 183, 184;

poverty caused by use of, 184.

Liquor interest, powerful political agency ...... 184 
Liquor problem, Committee of Fifty on, 9, 183, 184; economic aspects of, 183.

Liquor traffic, control of, in Connecticut ........ 185

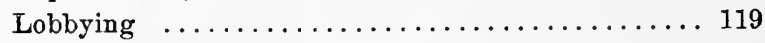

"Looking Backwards,", Bellamy's .......... 38

Lugano, meeting of International Association for

Labor Legislation in . .............. 120

Lyman, Dr., on employment of discharged tubercular patients .....................189, 190

MeCall, Hon. Samuel W., and experimental legislation in Oregon $\ldots \ldots \ldots \ldots \ldots \ldots \ldots \ldots \ldots . \ldots \ldots$

Machinery, effects of $\ldots \ldots \ldots \ldots \ldots \ldots \ldots \ldots$

Man, civilized, and struggle for supremacy over nature, 58-60; dealings of, with fellowmen, 60. Management, scientific, applied to economic science 32 Marine Hospital Service .............78, 79

Marriage, distribution of wealth by ......... 124 Massachusetts, Body of Liberties, 35; forest fires caused by smokers in, 182; General Hospital, social service department of, 112, 189; law limiting price of stocks in, 129.

"Master and servant" now an obsolete expression in labor laws ................... 69

Matches, non-poisonous marketed by New Jersey factory, 180; white phosphorus, 178-180.

Material, economic, buried in State archives ..... 50

Medical examination in Zeiss-Stiftung ........ 148 Medical school, of St. Louis, chair of preventive medicine in, 189; Yale, 188.

Medical science, social side of . ........... 112

Medical sociology, formation of society for study of 112 Medicine, economic considerations in, 189 ; preven-

tive, 188, 189; tendeney of science of, 8 .

Mental Hygiene, Society for ............. 190

Method, experimental in economics, 25, 32 ; historical 29 


\section{INDEX}

Methods, laboratory, 49; of agriculture, 42, 43; of organization, changes in, 68,71 ; of production, changes in, 68, 70, 71; of remuneration, 43 .

Migration, laws limiting ............. 84

Milan, hospital for industrial diseases in ..112, 187, 188

Mill, John Stuart, on deduction, 10; on experimestation, $5-7$; on unearned increment, 16.

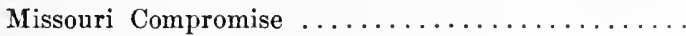

Monetary legislation, analogy of, to labor legislation ........................ $86-92$

Money, experience of world in dealing with, 86, 87;

loaning of, to employees by $Z$ eiss-Stiftung, 158 .

Moore, Prof. H. L., "Laws of Wages" .......30, 31

Morcs, of the people, 40 ; of time and country, 77, 78.

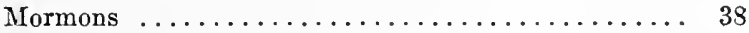

Mount Wilson Observatory ............... 11

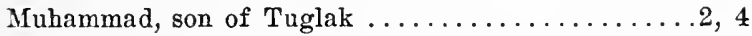

National Housing Association, organization of, 188, 189

Natural resources, exhaustion of $\ldots \ldots \ldots \ldots \ldots \ldots 25$

Natural sciences .................... 10, 12

Natural selection ................... 60

Nature, civilized man and, 58.60; deficiencies of, 25;

in state of equilibrium, 58 .

Necrosis, phosphorus, 15 ; international treaty to prevent, 178; legislation against, in U. S., 179, 180.

New England, 34; freehold in, 35; rule of primogeniture abandoned in, 35 .

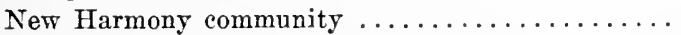

New Haven, directory of local charities in, 192;

fires caused by smokers in, 181; map showing cases of tubereulosis in, 188.

New Haren Organized Charities Association, local directory of charities made by .......... 192 New Jersey, non-poisonous matches marketed by

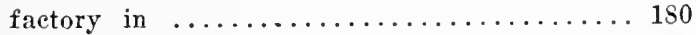
Newmareh, William $\ldots \ldots \ldots \ldots \ldots \ldots \ldots 26,28$ 


\section{INDEX}

New York, accidents in factories, quarries, and tunnel constructions in, 171; investigation of insurance in, 125; Triangle shirtwaist fire, responsibility for, 181; workmen's compensation law declared unconstitutional in, 175, 176.

New Zealand, compulsory arbitration in ........ 135

Observation in economies ................ 12

Old age insurance, German .............. 114

Old age pensions, in Great Britain, 114; introduced into Zeiss-Stiftung, 147; laws, 84.

Opportunity, equality of $\ldots \ldots \ldots \ldots \ldots \ldots \ldots \ldots$

Organization, changes in methods of, 68,71 ; indus-

trial, new forms of, 39 ; of labor, 36.

Organizations, labor, laws regulating ...........

Organized Charities Association of New Haven, direc-

tory of local charities by .............. 192

Parasitism in "leisure class" $45,47,48$

Parliament, British, Blackstone's opinion of, 104;

old age pension act and, 114 .

Past, records of the .................. 53

Patent laws, encourage inventions ........... 171

Patents, policy of Zeiss-Stiftung regarding . ...158, 159

Paternalism .................... 136

Pathology, economic .............25, 26, 48

Pearson, Karl ..................19, 22, 32

Pendulum, law of $\ldots \ldots \ldots \ldots \ldots \ldots \ldots \ldots \ldots \ldots$

Pensions, old age, Great Britain, 114; laws regarding, 84; Zeiss-Stiftung, 147, 150.

Peonage

$.43,62,132$

People, heterogeneity of, 41 ; responsibility rests

with, for endless chain of charity, 177.

Perfectionists .................... 38

Permissive labor legislation ........85, 86, 91, 92

Phenomena, analysis of $\ldots \ldots \ldots \ldots \ldots \ldots \ldots \ldots . \ldots \ldots$

Philanthropy, schools of ............... 191 


\section{INDEX}

Phosphorus, law prohibiting use of, in U. S. delayed

by habits of smokers . . . . . . . . . 178-180

Phosphorus bill .................... 179

Phosphorus necrosis $\ldots \ldots \ldots \ldots \ldots \ldots \ldots \ldots \ldots$ 15, 178

Pierstoff, Julius . .................. 138

Pioneers of frontier, compared to those of industry 61

Pisa, lamp in cathedral of $\ldots \ldots \ldots \ldots \ldots \ldots .54$

Pittsburgh Survey, exhibit of, 100-102; made under

direction of The Survey, 190.

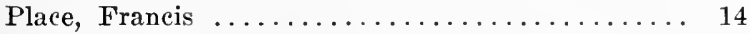

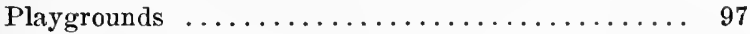

Poisons, industrial, list of . ............ 120

Polar explorations and the press $\ldots \ldots \ldots \ldots \ldots 65,66$

Policy, public land, of U. S. ............ 78

Poor relief, lavish, danger of, 91; experience of Great

Britain with, 114, 115.

Political questions, and economic interests ....... 36

Population, immigrant, 169 ; improvement in quality

of, 72, 73; increase in, 68, 69; Ricardo's theory

of increase of, 44 .

Posteritism ....................... 103

Poverty, caused by use of alcohol .........183, 184

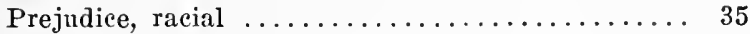

Preservation of race $\ldots \ldots \ldots \ldots \ldots \ldots \ldots \ldots \ldots .94$

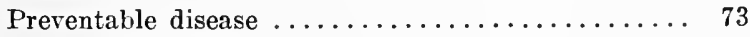

Preventive medicine, 188, 189; chair of, in St. Louis

Medical School, 189.

Primogeniture, rule of, abandoned in New England

Processes, economic, influenced by legal or institu-

tional factors, 124; mathematical, 30.

Production, 24; changes in methods of, 68, 70, 71;

depends upon legal form of contract, 130-137;

effect of labor on, 44 ; encouraged by corporation

laws, 171 .

Profit sharing, 136; in Zeiss-Stiftung, 153, 154.

Profits, limited by public opinion or law ......127.129 


\section{INDEX}

Progress, economic, Clark's elements of, 68-72;

involves labor legislation, 73 ; spirit of, 64 .

Prohibitory tax to prevent use of white phosphorus 179 Property rights, in inventions, 127 ; readiness to use

discovery as basis of, 66 .

Protective labor legislation .......84, 86-89, 94, 97 Protective tariff, 90, 171; Alexander Hamilton and,

79; Mill and, 5-7; wealth of nations and, 6, 10. Prussia, child labor laws of, 94; qualifications for factory inspectors in, 117, 118.

Public, restriction of profits in interest of . . . 128, 129

Public Health, Committee on, in Conn. ........ 106

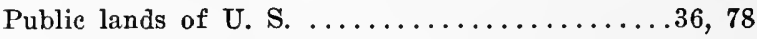

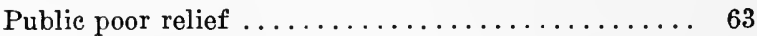

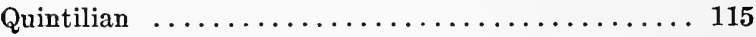

Race, liberty of, 78; purpose of labor legislation to maintain quality of, 94 .

Races, materials bearing upon mixture of, in U. S., 48 ; wars of, 35 .

Racial prejudice

Railroads, accidents on, in U. S., 171; æsthetic obligations of, 127, 128; enjoy right of eminent domain, 171 ; in U. S. compared with those in Germany and Switzerland, 128; law enacted requiring automatic couplers on, 173 .

Rane, F. W. ..................... 182

Reactions, economic, study of $\ldots \ldots \ldots \ldots \ldots 46,47$

Records, imperfection of, 51 ; inadequacy of, 50 ; of

operation of laws, necessity for, 52 .

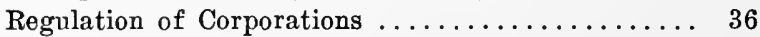

Religion, wars of $\ldots \ldots \ldots \ldots \ldots \ldots \ldots \ldots \ldots \ldots \ldots \ldots$

Remuneration, methods of ............... 43

Rent, affected by form of law, 123; determination of, 126.

Rente, in Guernsey ..............131, 132

Ricardo, David .................. 44 


\section{INDEX}

Rist, Charles ..................... 30

Roosevelt, Theodore ................... 59

Roscher, Wilhelm .................. 29

Ruskin Colony .................... 38

Safety appliances, laws requiring .......... 84

Sage Foundation, 65; investigation of salary ivan business by, 126.

St. Louis Medical School, chair of preventive medicine in ........................ 189

Salaries, of officials of Zeiss-Stiftung . . . . . 159

Samaritan, Good, and the good citizen, 186; parable of, 165 ; sequel to parable of, $166,167$.

Savings, compulsory ............... 92

Schloss, David .................... 133

Schmoller, Gustav von $\ldots \ldots \ldots \ldots \ldots \ldots \ldots$ 18, 27, 30

Schomerus, Dr. Fr. ..............138, 161

School, Chicago, of eivies and philanthropy, 191;

St. Louis Medical, 189; Yale Medical, 188.

Schools, law, 105; of agriculture, 65 ; of philanthropy, 191.

Schott, Dr. Otto .................. 140

Schumpeter, J. ................... 22

Science, application of, to agriculture, 64,65 ; contrasted with description, 53-54; "dismal," 55; economic, Jevon's contribution to, 28 ; economic, two phases of, 55, 56; of legislation, conspicuous by its absence from curricula of law schools, 105; working hand in hand with charity, 191.

Sciences, co-operation between, 112; natural, 10, 12.

Scientific economist, aim of $\ldots \ldots \ldots \ldots \ldots \ldots 21,22$

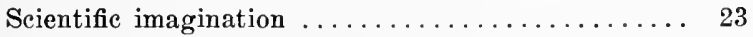

Scientific laws ...................22, 23

Scientific management, applied to economic science 32 Scientific method, see economic experimentation.

Scrap heap, human .................... 102 Selection, artificial, 60; natural, 60. 


\section{INDEX}

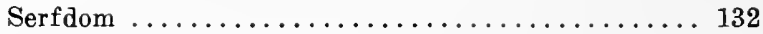

Sesquisulphide of phosphorus . .......... 179

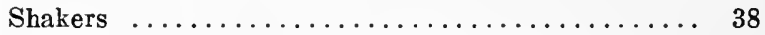

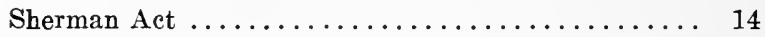

Sick insurance, in Germany, 79, 134; in merchant marine in U. S., 79 ; in Switzerland, 113; in Zeiss-Stiftung, 147, 149, 150.

Sickness, compulsory insurance against ...134, 147, 149 Silver ....................... 14

Single Taxers, Fairview Colony of ......... 38

Slavery, 36, 43, 62, 63; forms of, 132, 133.

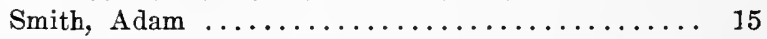

Smokers, cause of forest fires in Massachusetts, 182;

contributions to endless chain of charity by, 180-183; fires caused in New Haven by, 181; fires in Yale grandstand caused by, 181; raised to position of privileged class, 182, 183; responsible for Triangle shirtwaist fire, 181.

Social imagination, demanded by new charity ..... 166

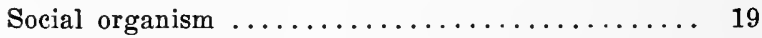

Social policy, experiments in ............ 28

Social service supplanting charity .......... 190

Social Utopias ................... 38

Socialism, 95, 96, 103; advocated as remedy, 63, 64; among employees in Zeiss-Stiftung, 162, 163; argument for, 47.

Societies, benefit, 85 ; to promote reform, 39 .

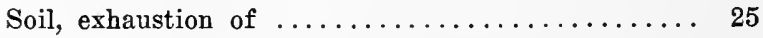

Somerfeld, Prof. Th. ................ 120

Southern Pacific Railroad Company vs. Johnson 173, 174

Spaniards and coartación ............... 133

Special favors, distribution of wealth by ....... 125

Spoils system ................... 98

State, intervention of, in labor, 89 ; necessary, 73.

Statistical laws ................... 23 
Statistics, imperfection of vital and accident, 111; vital, registration of, 99 .

Stiftungs-Verwaltung, of Zeiss-Stiftung .....145, 153

Strike, anthracite coal ................ 19

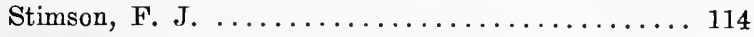

Straubel, Rudolf .................. 142

Struggle for existence, civilized man and ....... 60

Supply and demand, law of, limited by public opinion

or law, 127-129; not affecting distribution of wealth, 123-125.

Surplus income .................... 24

Survey, The, Pittsburgh Survey made under direc-

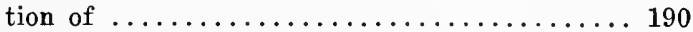

Sweden, average duration of life in ........ 72

Switzerland, Civil Code of, provides for Gült, 132;

investigation of sick insurance in, 113 ; railroads of, compared with those of the U. S., 128.

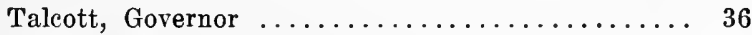

Tariff duties ...................... 126

Tax, prohibitory, on poisonous matehes ....... 109

Taxation, 43 ; incidence of, 24.

Taximeter, a means of avoiding disputes ....... 135

Taylor, Frederick W. ................ 44

Team work, need of, 31 ; in charity work, 187.

Tenancy, free ................... 43

Tenement house laws, 69 ; in Connecticut, 188.

Trade Unions ................14, 20, 43, 75

Treaties, international, 71 ; legislation a subject for, 99.

Triangle shirtwaist fire, responsibility for ....... 181

Tuberculosis, 97, 168; deaths from, in Pittsburgh, 102; due to conditions of living in large cities, 188; employment of patients recovering from, 190 ; map showing cases of, in New Haven, 188. Tunnel constructions, accidents in New York State in 
Turner, Frederic J. ................ 53

Typhoid fever, deaths from, in Pittsburgh ...... 101

Unconstitutionality, bugaboo of .......... 108

Unearned increment, taxation of $\ldots \ldots \ldots \ldots \ldots 16$

Unemployment, insurance against, 92 ; statistics of involuntary, 48.

United States, accidents in coal mines in, 171; advantage of, as an experiment station, 37 ; as a legislative problem, 98 ; average duration of life in, 72; backwardness of law-making in, 100; common basis of English language and law in, 41 ; compared with British colonies, 37; compared to hospital, 37 ; difficulties in movement for posteritism in, 97-102; disregard of human scrap heap in, 102; economic ideal of, 77.80; experimentation interrupted in, 49 ; heterogeneity of people in, 41 ; history of economic experimentation in, 42; history of, compared with Europe, 34, 35; labor unions in, 92; marine hospital insurance in, 78, 79; number insured in fraternal and benefit societies in, 113; number of accidents on railroads in, 171, 172; number of fatal accidents in, 172; public land policy of, 78 ; railroads in, compared with those of Germany and Switzerland, 128; untrained legislators in, 99, 100, 105.

United States Steel Corporation ............ 164

Utopias, social, in the U. S. ............ 38

Visiting nurses ................... 190

Vital statisties, registration of $\ldots \ldots \ldots \ldots \ldots \ldots . . \ldots 9$

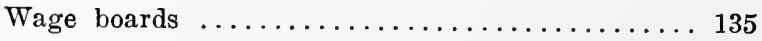

Wage contract ............... 132-135

Wage receivers, and experimentation ........ 40

Wage system, forms of contract of .......... 133

Wages, affected by form of law or eustom, 123; fixing of, by wage boards, 85 ; influenced by 
other factors than law of supply and demand, 129, 130; in Zeiss-Stiftung, 149; "Laws of,", 31 ; observation of Mr. Taylor on, 44; rates of, 43 ; Ricardo and, 44 ; systems of, 43.

Wants, changes in consumers $\ldots \ldots \ldots \ldots 6,71,72$ Wars of race, 35 ; of religion, 34 .

Wealth, distribution of, 24, 62 ; distribution of, without reference to law of supply and demand, 123127; hereditary, 45 ; increase in capital tends to make large aggregations of, 69 ; irresponsibility of, in U. S., 47 ; reaction of, upon efficiency of labor, 44; transfer of, by law, 91, 124.

Wealthy families, parasitic members of $\ldots .45,47,48$ Whateley, Richard, definition of catallactic ...... 123 Wills, distribution of wealth by ........... 124

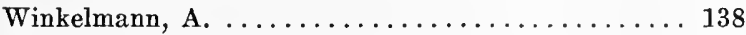

Wisconsin Legislative Reference Library ........ 100 Women, argument for protecting, 94; failure to protect, 107; lack of adequate laws for protection of, 98 ; laws limiting hours of employment of, 84.

Woods, Frederick Adams, 31, 46; on vices of aristocracy, 45.

Worker, displacement of skilled, by unskilled, 70; sick or superannuated, 63 .

Workingmen, budgets of $\ldots \ldots \ldots \ldots \ldots \ldots \ldots$

Workmen's compensation, 108, 174-176; a problem of labor legislation, 70; economies of decision against New York State law on, 176; New York State law declared unconstitutional, 175, 176 ; principle of, 174, 175; treaty for, 71.

Workmen's insurance, 70, 90; arguments for, 94; compulsory, 108, 134; compulsory, for carrying burden of accidents, 134, 174-176; see also insurance.

Yale Medical School ................... 188 
Zeiss, Carl, birth and education, 138; death of, 142; establishment of business, 138, 139; growth of business, 141; interest of, in Schott und Genos. sen, 140 .

Zeiss-Stiftung, complicated nature of, 143 ; conditions of ownership of, 143, 144; criticisms of, 162 ; employees appointed without reference to race, etc., 148; founding of, 142; general sum. mary of results of, 160, 161; gifts to University of Jena and for public purposes by, 159, 160; guarantees minimum weekly compensation, 148; holidays, 148; hours of labor in, 148, 155-157; indemnity to discharged employees of, 150, 151; insurance features of, 147, 149; interest and significance of, 163, 164; leave of absence for serrice of Empire or state granted to employees, 148; medical examination of jurenile workers, 148 ; notice to be given before leaving works, 150 ; organization of, and management of, 145, 146; patents, 158, 159; pensions, 150; profit sharing with employees, 153, 154; profits set aside for interests of industry or science, 153; purposes of, 144; relations of employees of, to establishment, 146, 147; reserve fund of, 152; salaries of officials of, 159 ; savings bank of, 148; sick fund of, 149; socialists among workmen in, 162, 163; Stiftungs-Verwaltung of, 145, 153; strikes in, 161; under ultimate control of government, 145; Vorstände of, 145 ; wages of, 149 ; welfare work of, 158. 




